\title{
ATTEMPTS TO REDUCE DRUG RESISTANCE OF BACTERIA AND CANCER CELLS
}

\author{
Ph.D. Thesis
}

Gabriella Spengler

Department of Medical Microbiology and Immunobiology

Faculty of Medicine

University of Szeged

Szeged

2006 
TABLE OF CONTENTS

PUBLICATIONS RELATED TO THE THESIS

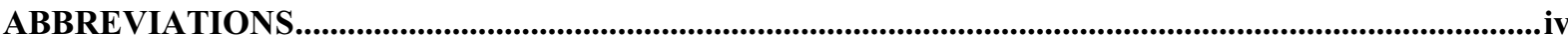

INTRODUCTION

THE ERA OF RESISTANCE AS CONSEQUENCE OF EXTENDED USE OF ANTIBIOTICS ......................................... 1

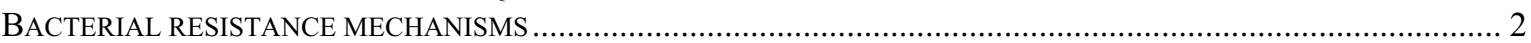

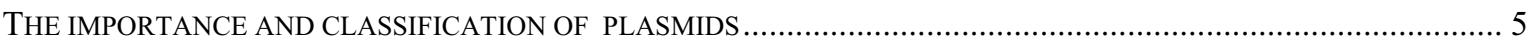

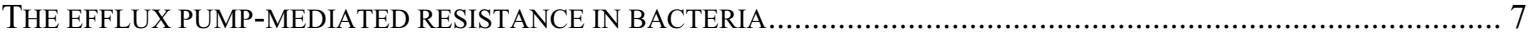

DRUG RESISTANCE IN EUKARYOTES: ORIGIN OF BACTERIAL MODEL FOR MULTIDRUG EFFLUX PUMPS IN CANCER

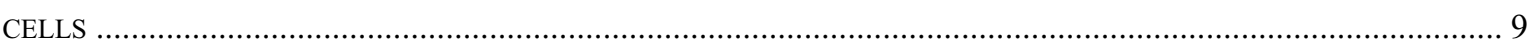

THE BACKGROUND OF THE THESIS: FROM ANTIPLASMID EFFECT TO MULTIDRUG RESISTANCE REVERSAL........ 11

AIMS OF THE STUDY ...........................................................................................................................................13

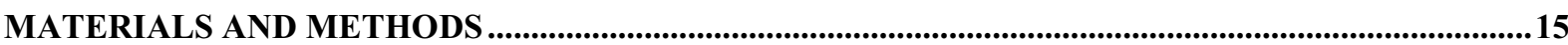

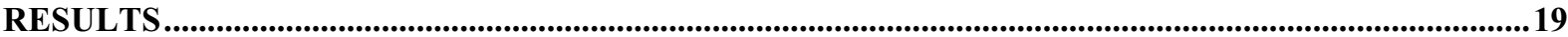

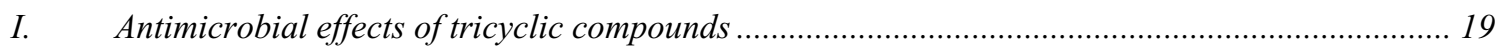

II. Plasmid elimination by tricyclic compounds.................................................................. 19

1. Plasmid curing experiments for F'lac plasmid elimination ...................................................................... 19

2. Plasmid curing experiments for elimination of doxycycline resistance .......................................................... 21

III. Interactions of antiplasmid compounds with plasmid DNA ............................................... 22

1. Clarification of the mechanism of action of different chemicals, antiplasmid compounds on model nucleic

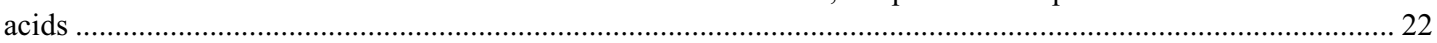

2. Complex formation of antiplasmid compounds with the isolated plasmid DNA from clinical strains .............24

3. Identification of $\mathrm{Tc}^{\mathrm{r}}$ plasmid by isolation and retransfer from clinical isolate of $E$. coli ................................ 26

IV. The effect of proton pump inhibitor 1-(2-benzoxazolyl)-3,3,3-trifluoro-2-propanone [TF18] on the

action of resistance modifiers in model experiments ..................................................................... 26

1. Interaction between proton pump inhibitor and antiplasmid compounds from the aspect of antibacterial effect

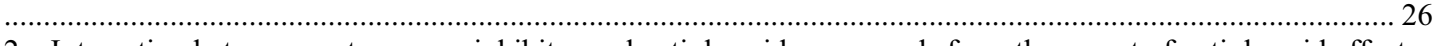

2. Interaction between proton pump inhibitor and antiplasmid compounds from the aspect of antiplasmid effect

3. .

on the elimination of doxycycline resistance on E. coli 42883 doxycycline resistant clinical strain...................28

4. Specific effect of proton pump inhibitor on a model of Helicobacter pylori: antibacterial and antimotility studies......

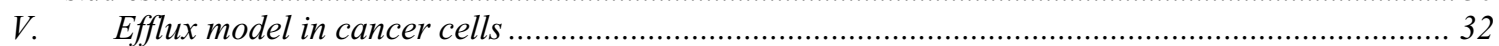

A. Synthetic compounds designed to block the P-gp mediated efflux .............................................................. 32

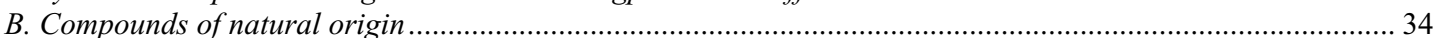

VI. Apoptosis induction as an alternative cell death on mouse lymphoma cells.............................. 34

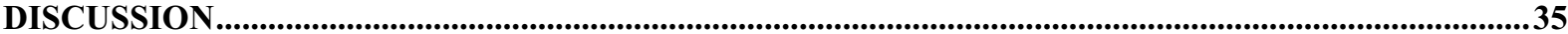

NEW SCIENTIFIC RESULTS RELATED TO THE THESIS.............................................................................42

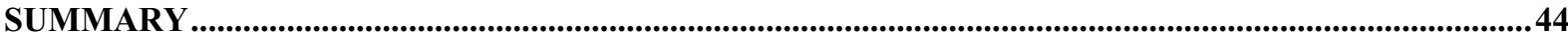

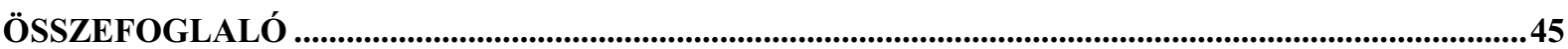

REFERENCES

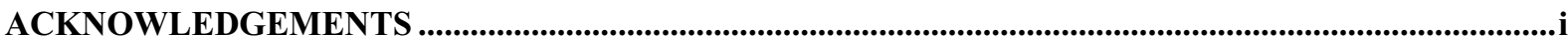

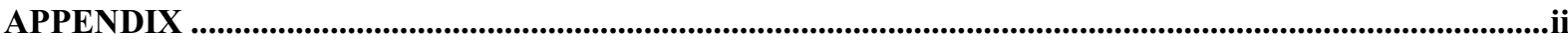

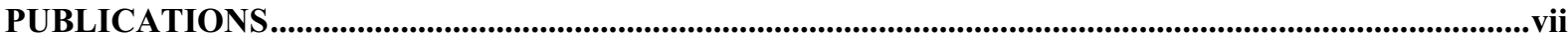




\section{PUBLICATIONS RELATED TO THE THESIS}

I Misbahi H, Brouant P, Hevér A, Molnár A, Wolfárd K, Spengler G, Mefetah H, Molnár $\mathrm{J}$, Barbe J: Benzo[b]-1,8-naphthyridine derivatives: synthesis and reversal activity on multidrug resistance. Anticancer Res. Jul-Aug;22(4):2097-101, $2002 . \quad$ IF: 1.395

II Rao BK, Motohashi N, Kawase M, Spengler G, Molnár J: Multidrug resistance reversal in mouse lymphoma cells by Indian tea leaves, Indian coffee seeds and chicory. Oriental Pharmacy and Experimental Medicine 3(2), 100-105, 2003.

III Kawase M, Motohashi N, Satoh K, Sakagami H, Nakashima H, Tani S, Shirataki Y, Kurihara T, Spengler G, Wolfárd K, Molnár J: Biological activity of persimmon (Diospyros kaki) peel extracts. Phytother Res. May;17(5):495-500, 2003.

IF: 0.975

IV Spengler G, Miczák A, Hajdú E, Kawase M, Amaral L, Molnár J: Enhancement of plasmid curing by 9-aminoacridine and two phenothiazines in the presence of proton pump inhibitor 1-(2-benzoxazolyl)-3,3,3-trifluoro-2-propanone. Int J Antimicrob Agents, Sep 22(3):223-7, 2003

IF: 2.064

V Madureira AM, Spengler G, Molnár A, Varga A, Molnár J, Abreu P, Ferreira MJ: Effects of cycloartanes on reversal of multidrug resistance and apoptosis induction on mouse lymphoma cells. Anticancer Research, 24:865-72, 2004.

IF: 1.395

VI Spengler G, Molnár A, Klausz G, Mándi Y, Kawase M, Motohashi N, Molnár J: Inhibitory action of a new proton pump inhibitor, trifluoromethyl ketone derivative, against the motility of clarithromycin-susceptible and-resistant Helicobacter pylori. Int $\mathrm{J}$ Antimicrob Agents, June 23(6):631-633, 2004.

IF: 2.064

VII Molnár J, Molnár A, Spengler G, Mándi Y: Infectious plasmid resistance and efflux pump mediated resistance. Acta Microbiol et Immunol Hung. 51(3) 333-349, 2004.

VIII Spengler G, Molnár A, Klausz G, Mándi Y, Kawase M, Motohashi N, Molnár J: The antimotility action of a trifluoromethyl ketone on some Gram-negative bacteria. Acta Microbiol Immunol Hung. 51(3):351-358, 2004.

IX Sharples D, Spengler G, Molnár J, Antal Zs, Molnár A, Kiss T.J, Szabó A.J, Hilgeroth A, Gallo S, Mahamoud A, Barbe J: The interaction between resistance modifiers such as pyrido[3,2-g]quinoline, aza-oxafluorene and pregnane derivatives with DNA, plasmid DNA and tRNA. Eur J Med Chem 40:195-202, 2005.

IF: 1.673

X Kawase M, Sakagami H, Motohashi N, Hauer H, Chatterjee S, Spengler G, Varadi A, Molnár A, Molnár J: Coumarin derivatives with tumour-specific cytotoxicity and multidrug resistance reversal activity. In Vivo 19:705-712, 2005.

IF: 0.811 

PMZ Promethazine
TFP Trifluoperazine
9-AA 9-aminoacridine
MIC Minimal Inhibitory Concentration
FIC Fractional Inhibitory Concentration
FIX Fractional Inhibitory Index
EMB Eosin methylene blue
MTY Minimal Trypton Yeast Broth
LB Luria Bertani Broth
CRHP Clarithromycin Resistant Helicobacter pylori
CSHP Clarithromycin Sensitive Helicobacter pylori
CT DNA Calf Thymus DNA
P-gp P-glycoprotein
E. coli
Escherichia coli
S. typhimurium
Salmonella typhimurium
P. aeruginosa
Pseudomonas aeruginosa
S. aureus
Staphylococcus aureus
Y. enterocolitica
Yersinia enterocolitica

ABBREVIATIONS

MDR multidrug resistance
ABC-transporter
ATP-Binding Cassette-transporter
ds DNA double stranded DNA
GC guanine-cytosine
PMF proton motive force
HlyB haemolysin B protein
MRP multidrug resistance protein
BCRP breast cancer resistance protein
TMD transmembrane domain
NBD nucleotide binding domain
F'lac F prime lactose metabolic plasmid
$\mathbf{T c}^{\mathrm{r}}$ tetracycline resistance
Exp1-3 experiment 1-3
SD standard deviation

FAR Fluorescence Activity Ratio 
We need roots. We need wings.

Blessed is he who has wings and roots,

and wretched is he who only has one of the two.

(Paulo Coelho) 


\section{INTRODUCTION}

\section{The era of resistance as consequence of extended use of antibiotics}

The triumph of antibiotics to combat bacterial infections is one of modern medicine's greatest success stories. During the period between Fleming's great discovery in 1929 and Florey and co-workers' advancement of penicillin, a few other notable findings in the search for antibiotics were made. In 1932, Domagk investigated different chemicals for their effects on bacterial infections and he found that the dye Prontosil cured diseases caused by the streptococcus bacteria. Later work showed that the active group of Prontosil was not the dye part of the molecule, but the sulfonamide group attached to it. In 1943, Selman Waksman and his group isolated another antibacterial agent from a soil bacterium, Streptomyces griseus. Waksman's antibiotic, the streptomycin, proved to be effective against several common infections. Most noteworthy was its ability to kill the bacterium Mycobacterium tuberculosis, the microbe causing tuberculosis, which had resisted numerous methods of treatment before. Since these drugs first became widely used in World War II, they have saved countless lives and blunted serious complications of many feared diseases and infections.

After more than 50 years of widespread use, the overuse and sometimes misuse of antimicrobials in both human and veterinary medicine has resulted in the emergence of strains of bacteria that were no longer susceptible to antimicrobial therapy. In his 1945 Nobel Prize acceptance lecture Alexander Fleming reminded the audience of the dangers of inappropriate use of penicillin: „But I would like to sound one note of warning. Penicillin is to all intents and purposes non-poisonous so there is no need to worry about giving an overdose and poisoning the patient. There may be a danger, though, in underdosage. It is not difficult to make microbes resistant to penicillin in the laboratory by exposing them to concentrations not sufficient to kill them, and the same thing has occasionally happened in the body" (1).

Resistance to penicillin in some strains of staphylococci was recognized almost immediately after introduction of the drug. The period of the late 1940s and early 1950s saw the discovery and introduction of streptomycin, chloramphenicol and tetracycline, and the age of antibiotic chemotherapy came into full being. These antibiotics were effective against the full array of bacterial pathogens including Gram-positive and Gram-negative bacteria, intracellular parasites, and the tuberculosis bacillus. However, by 1953, during a Shigella outbreak in Japan, a strain of the dysentery bacillus was isolated which was multiple drug resistant, showing resistance to chloramphenicol, tetracycline, streptomycin, and the sulfonamides (2). 
Factors that drive the dissemination of antibiotic resistance are numerous and diverse. The molecular characteristics of pathogens, such as transmissibility and fitness play an important role in emerging of resistant microbes, furthermore the overuse of antibiotics prescribed by physicians, who should change the antibiotics according to the resistance pattern of bacteria $(3,4)$.

\section{Bacterial resistance mechanisms}

Bacteria have evolved mechanisms to avoid the inhibitory action of antibiotics as a result of chromosomal mutation or by exchange of genetic elements, which carry resistance genes, and transfer can occur through conjugation, transformation, transduction $(5,6)$. Selection may also favour determinants that prevent their own counter selection and resistant strains with enhanced survival ability or virulence.

Antibiotic resistance may be an inherent or intrinsic property of a bacterium, or it may be an acquired characteristic. Examples of inherent resistance include the resistance of most Gramnegative bacilli to vancomycin, of enterococci to cephalosporins, and of anaerobic bacteria to aminoglycosides. Acquired resistance may result from mutations in existing DNA or acquisition of new DNA. Mutations in DNA may be chromosomal, but can also occur in genes residing on plasmids or transposons. Plasmids (extrachromosomal DNA elements that can replicate independently of the chromosome) are probably the most common means of transferring resistance genes in nature. Some plasmids have broad host ranges and can transfer genes between species. An example of this is the transfer by plasmids of genes encoding $\beta$-lactamase production and high-level gentamicin resistance from staphylococci to enterococci. Other plasmids have much more restricted host ranges. Transposons, the socalled jumping genes, are DNA elements that can encode for their own movement from one place in the DNA to another. Genes encoding for vancomycin resistance in enterococci may be carried on transposons (7). 
The spread of resistance can occur by three ways in nature, such as conjugation, transduction and transformation:

Conjugation plays an important role in the spread of antibiotic resistance through bacteria. This process involves direct cell-to-cell contact of two bacterial cells, and the subsequent transfer of DNA.

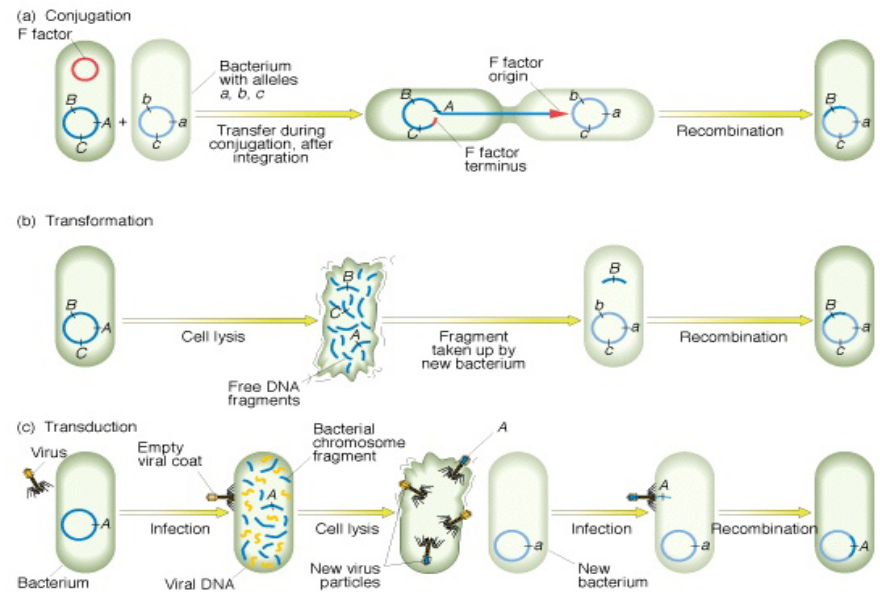

Figure 1. Spread of resistance genes (http://www.fig.cox.miami.edu) Conjugative plasmids transfer themselves between most bacteria, moreover, DNA can be transferred conjugatively into eukaryotic host cells, for this reason, a large gene pool is available from which bacteria can exchange and acquire new genetic material $(7,9)$. Sex pili make contact between the donor and the recipient cell. Once the two cell walls are in contact, this allows a mating bridge to form. The plasmid DNA in the donor containing antibiotic resistance genes, is nicked in one strand; this strand proceeds into the recipient cell by undergoing rolling-circle replication in both bacteria (12).

Transduction occurs when a bacteriophage carries DNA from one species to another. When a bacteriophage destroys its current host and invades a new one, it may carry pieces of chromosomal DNA or plasmids from the previous host. An occasional phage may carry some bacterial DNA. Recombination can then occur between the phage (carrying bacterial DNA) and the new host's bacterial DNA $(13,14)$.

Transformation is another method of acquiring resistance. During transformation, bacterial cells take up DNA from the surrounding environment, such as after cell lysis. Bacteria have mechanisms that allow the DNA to be taken up through the bacterial cell walls. The transport of DNA from the extracellular milieu into the cytoplasm requires proteins that are related to those involved in the assembly of type IV pili and type II secretion system (15). Also, the DNA must be incorporated into the chromosome of the competent host, often by homologous recombination (16).

Both chromosomal mutations (17) or genetic transfer can be responsible for the resistance acquisition. A mutation that confers resistance in one step is relatively rare, but it has been well documented for certain agents, such as quinolines, rifampin, streptomycin, sulphonamides and trimethoprim (14). The transferable resistance is carried on drug 
resistance $\underline{R \text { plasmids }}$, which can carry genes coding multiple drug resistance. The resistance genes themselves are often located on discrete movable DNA elements called transposons (18). In general, two classes of transposons are known: class I and class II. Class I transposons can transpose only after a round of DNA replication because there is no replication of the transposon during the transposition. Class II transposons contain a transposase, which sets up a co-integrate intermediate between the transposon-containing replicon and the target replicon, and a resolvase, which separates the co-integrate into the original two replicons with a copy of the transposon in each $(19,20)$.

Nowadays the emerging of resistant microbes is not due to the accumulation of small mutations within one species (vertical evolution); the horizontal evolution is the driving force for the appearance of new resistance patterns among microbes because of the pathogenicity islands $(21,22)$.

The various mechanisms of resistance $(23,24,25,26)$ can be due to

- Impermeability of drug: this is the most frequent cause of intrinsic resistance, e.g. Enterococcus, Pseudomonas.

- Alteration of target molecules in bacterial cell: this is one of the most important mechanisms of resistance to clinically used antibacterial drugs, e.g. methicillin resistant $S$. aureus with altered penicillin binding proteins; many antibiotics inactivate a specific enzyme or, as in the case of a large number of protein synthesis inhibitors, the ribosome. The ribosome of staphylococci can become insensitive to erythromycin following specific enzymatic modifications of rRNA.

- Enzymatic drug modifications: Antibiotics can be inactivated either by enzymatic cleavage or by chemical modification. Chemical modification can confer clinical resistance to the aminoglycoside antibiotics, chloramphenicol, penicillins, cephalosporins and other $\beta$-lactams, e.g. $\beta$-lactamase enzymes currently account for most of the resistance to penicillins and cephalosporins; aminoglycosides destroyed due to the action of aminoglycoside-modifying enzymes produced by bacteria.

- Efflux: The efflux pumps of bacteria e.g. the primary and secondary efflux pumps extrude drugs from the bacterial cell. The transport proteins play an important physiological role in the extrusion of naturally occurring toxic substances and antibiotics, e.g. AcrAB pump in $S$. typhimurium, MexAB-OprM pump in P. aeruginosa (26).

- Resistant metabolic pathways: Bacterial cells that produce greater amounts of the enzyme may be able to produce a sufficient amount of the metabolic product to survive in the 
presence of the drug, e.g. bacteria that produce more folic acid reductase are resistant to trimethoprim.

- Failure to metabolise the drug: When drugs need to be converted by bacteria into the active form, failure to metabolise the drug will result in resistance, e.g. Bacteroides fragilis does not metabolise the nitroimidazole derivative metronidazole to the active metabolite and are therefore resistant to this drug.

Figure 2. Biochemical mechanisms of resistance, their structural localisation and the antimicrobial agents affected. (Taken from Sundsfjord A et al: Genetic methods for detection of antimicrobial resistance APMIS 112:815-37, 2004)

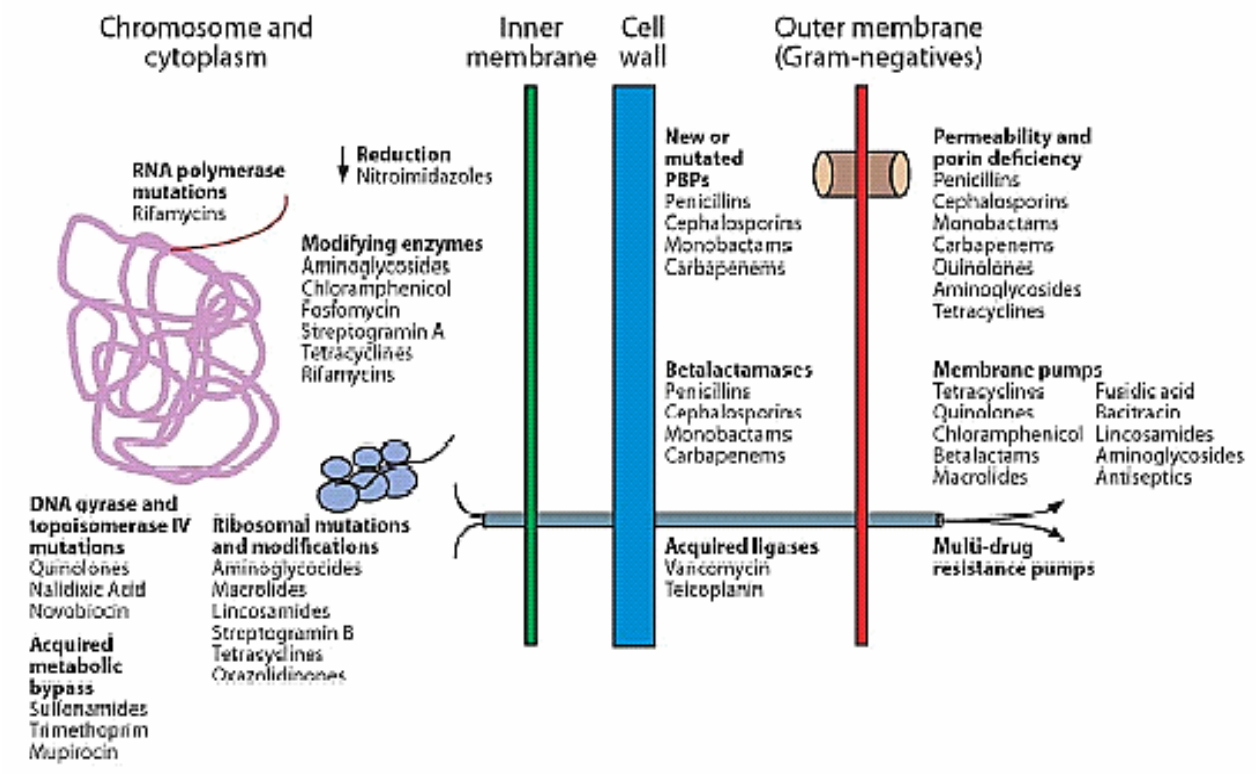

\section{The importance and classification of plasmids}

Plasmids are typically small genetic elements that exist and replicate separately from the chromosome. The great majority of the plasmids are double-stranded DNA, and although most plasmids are circular, some are linear. Naturally occurring plasmids vary in size from 1 to more than 1000 kilobase pairs. The typical plasmid is a circular double-stranded DNA molecule less than $1 / 20$ the size of the chromosome. The copy number varies from 1 or 2 per chromosome (e.g. F plasmid) to 40 or 50 (e.g. ColEl). Conjugative plasmids are those that mediate conjugation. These plasmids are usually large and have all the genes necessary for autonomous replication and for transfer of DNA to a recipient (e.g. genes for sex pilus) $(10,11)$. Nonconjugative plasmids are those that cannot mediate conjugation. They are usually smaller than conjugative plasmids and they lack one or more of the genes needed for transfer of DNA. A nonconjugative plasmid can be transferred by conjugation if the cell also harbours a second conjugative plasmid. Plasmids having the ability to integrate into the host chromosomes are called episomes. Most of the plasmid DNA isolated from cells is in the 
supercoiled configuration, which is the most compact form within the cell. A single break (nick) in one of the two strands causes the supercoil to convert to an open circular form, and when breaks occur in both strands at the same place, a linear duplex structure is formed (27).

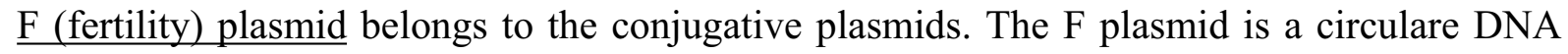
molecule of approximately 100 kilobase pairs. One region of the plasmid contains genes involved in regulating DNA replication (such as incompatibility, inc, and origin of replication oriS) (28). It contains also a number of transposable elements involved in its ability to function as an episome. It has a large region of DNA, the tra region, containing genes that permit it to be transferred from one cell to another (29). Bacteria having an $\mathrm{F}$ plasmid are $\mathrm{F}^{+}$ or male, $\mathrm{F}^{-}$cells without $\mathrm{F}$ plasmid are female. When $\mathrm{F}$ plasmid is integrated into the host chromosome, the cells are termed as Hfr cell (high frequency of recombination), because homologous recombination occurs at a high frequency between the bacterial chromosome and the introduced DNA.

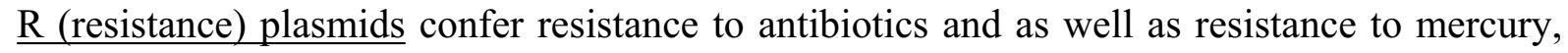
cadmium, nickel, cobalt, zinc and arsenic in Pseudomonas (30). R-plasmids were discovered first in Japan in dysentery causing Shigella shown to be transferred to and from intestinal $E$. coli. Sulfonamide (Sul) resistance was found first, followed rapidly by tetracycline (Tet), chloramphenicol (Cam) and streptomycin (Str) (2). R plasmids are conjugative plasmids in which the genes for replication, partition and transfer (resistance transfer factors) are located on one part of the $\mathrm{R}$ factor and the resistance genes are located on another part (31). The resistance genes are often parts of transposons. Many R plasmids and F plasmids have related tra regions, and recombination can occur between $\mathrm{F}$ and $\mathrm{R}$ plasmids.

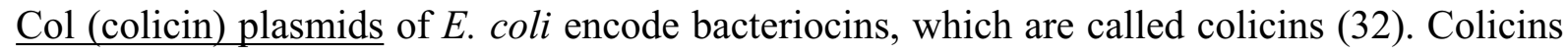
and bacteriocins are lethal proteins made by one bacterial strain to kill other bacteria. The structural gene for the bacteriocin and the genes encoding proteins involved in processing and transporting bacteriocin are often carried by a plasmid or a transposon (33). Colicins can be divided into two groups, such as pore-former and nuclease colicins.

Virulence plasmids are related to the adhesion, colonisation in the host organism and the damage of the host by formation of substances such as toxins, enzymes, and other molecules. The haemolysin and enterotoxin in enteropathogenic E. coli are encoded by plasmid (34), moreover the exfoliative toxin in $S$. aureus is known to be plasmid-linked (35), furthermore the two Bacillus anthracis toxins are composed of three proteins, protective antigen, lethal 
factor, and edema factor, and the structural genes for these three components are located on the virulence plasmid pXO1 (36). The circular Ti plasmid of Agrobacterium tumefaciens enables the bacterium to infect plant cells and produce a tumour (crown gall tumour) (37).

Metabolic plasmids take part in various physiological functions, for example lactose and sucrose utilization $(38,39)$. The first reports of catabolic pathways encoded by plasmids were made in the early 1970s. These were for catabolism of camphor, octane, naphthalene, salicylate and toluene and were all found in strains of the Gram-negative genus Pseudomonas (40). The Rhizobium species nodulate the legumes because of nod, sym and fix genes located on plasmids, which are necessary for nitrogen fixation (41).

Cryptic plasmids confer no identifiable phenotype on the host cell. The properties of these cryptic plasmids are presumably of some use to the host cell but are still unknown.

\section{The efflux pump-mediated resistance in bacteria}

Microorganisms have developed various ways to resist the toxic effects of antibiotics and other drugs. One such mechanism involves the cytoplasmic membrane-localised transport system, which takes part in normal physiological functions of the cells such as nutrient uptake, excretion of toxic metabolites and compounds, and maintenance of the cell homeostasis (42). Multidrug efflux pumps have been defined as membrane translocases, which are able to export a broad variety of structurally unrelated compounds (43). Some transporters, such as the tetracycline efflux proteins (44), are dedicated systems which mediate the extrusion of a given drug or class of drugs. In contrast to these specific drug transporters, the so-called multidrug transporters can handle a wide variety of structurally unrelated compounds (45).

On the basis of bioenergetics and structural criteria, multidrug transporters can be divided into two major classes. Secondary multidrug transporters utilize the transmembrane electrochemical gradient of protons or sodium ions to drive the extrusion of drugs from the cell. ATP-binding cassette (ABC)-type multidrug transporters use the free energy of ATP hydrolysis to pump drugs out of the cell (46). 
Figure 3. Schematic representation of the two major classes of multidrug transporters.

(A) ABC-type multidrug transporters utilize the free energy of ATP hydrolysis to pump drugs out of the cell. (B) Secondary multidrug transporters mediate the extrusion of structurally unrelated drugs in a coupled exchange with protons or sodium ions.

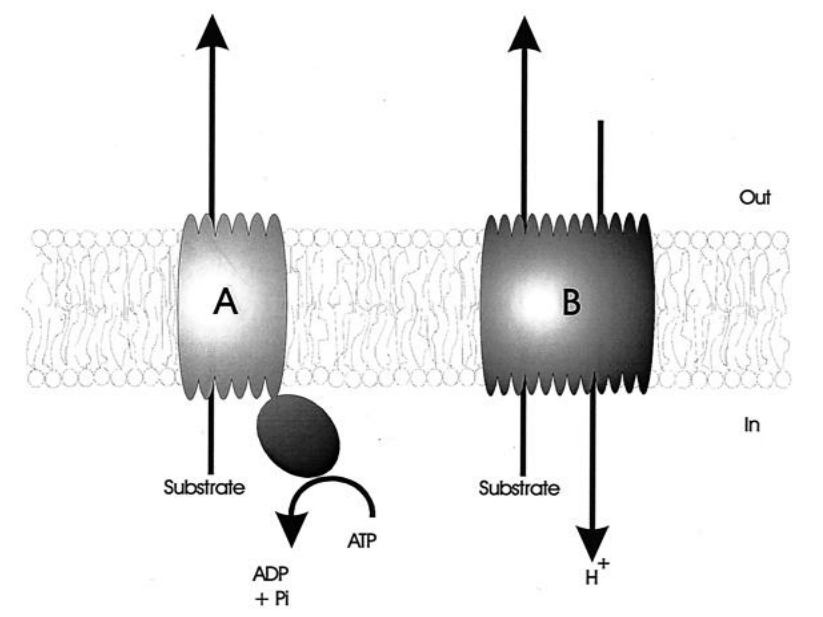

(Figure taken from Microbiol Mol Biol Rev. 2000 December; 64(4): 672-693.)

\section{Secondary multidrug transporters}

\section{Major Facilitator Superfamily (MFS)}

The MFS consists of membrane transport proteins which are found from bacteria to higher eukaryotes and are involved in the symport, antiport, or uniport of various substrates, such as sugars, Krebs cycle intermediates, phosphate esters, oligosaccharides, and antibiotics (47). They have 12 or 14 transmembrane segments (TMS) and some examples are the proteins EmrB(48) of E. coli; NorA (49) and QacA (50) of S. aureus; Bmr (51) of Bacillus subtilis. NorA and Bmr contain 12 transmembrane segments, QacA and EmrB are 14-TMS transporter proteins.

\section{Small Multidrug Resistance Transporter Family (SMR)}

Multidrug transporters of the SMR family are the smallest secondary drug transporters, which might function as homooligomeric complexes. The first gene encoding a transporter protein of the SMR family was found on both conjugative and nonconjugative plasmids from clinical isolates of S. aureus (46). The Mmr of Mycobacterium tuberculosis (52), QacE of Klebsiella aerogenes (53) and EmrE of E. coli (54) are members of this transporter family.

\section{Resistance-Nodulation-Cell Division Family (RND)}

Transporters belonging to the RND family interact with a membrane fusion protein and an outer membrane protein to allow drug transport across both the inner and outer membrane of Gram-negative bacteria. Members of this family have 12 TMS, with two large loops between TMS1 and 2 and TMS 7 and 8 (42). Examples of these proteins are AcrB of E. coli $(55,56)$, MexB of P. aeruginosa (57) and MtrD of Neisseria gonorrhoeae (58). 


\section{Multidrug and Toxic Compound Extrusion Family (MATE)}

NorM of Vibrio parahaemolyticus (59) and YdhE of E. coli (60) are members of the MATE family and posses 12 TMS. They are similar to the MFS, but do not exhibit any of the signature sequences (46).

Figure 4. Schematic illustration of the main types of bacterial drug efflux pumps. (Figure taken from Schweizer HP: Efflux as a mechanism of resistance to antimicrobials in Pseudomonas aeruginosa and related bacteria: unanswered questions. Genet. Mol. Res. 2 (1): 48-62, 2003)

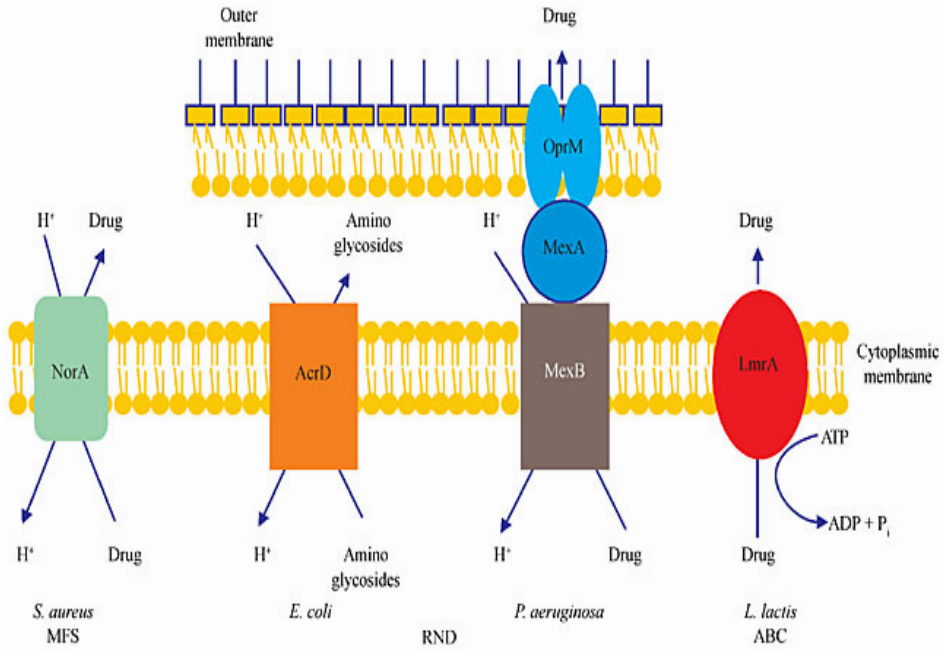

The secondary multidrug transporters are driven by the proton motive force (PMF) of the transmembrane electrochemical gradient of protons or possibly sodium ions. The PMF is composed of a chemical proton gradient $(\Delta \mathrm{pH}$, inside alkaline) and an electric potential $\quad(\Delta \Psi, \quad$ inside negative)(46,61).

There are other systems in bacteria, which use the proton motive force. The bacterial flagellar motor harnesses ion flow to drive rotary motion, at speeds reaching $100,000 \mathrm{rpm}$ and with apparently tight coupling $(63,64,65,66)$.

\section{ATP-dependent multidrug transporters}

The primary active transport is driven by ATP hydrolysis. The first evidence on an ATP dependent transport system, which conferred multidrug resistance in prokaryotes was obtained from studies of LmrA transporter of Lactococcus lactis (42).

\section{Drug resistance in eukaryotes: origin of bacterial model for multidrug efflux pumps in cancer cells}

$\mathrm{ABC}$ transporters of Gram-negative bacteria that mediate protein export require additional outer-membrane proteins to facilitate translocation across the periplasm and through the outer membrane e.g. haemolysin transporters (67). The P-glycoprotein responsible for the multidrug resistance of many types of cancer cells has sequence similarity with a family of bacterial transporter proteins, e.g. haemolysin. Gerlach et al (68) detected extensive homology between P-glycoprotein and the HlyB protein, a 66K Escherichia coli membrane protein required for the export of haemolysin (protein of Mr 107K). P-glycoprotein can be viewed as a tandem duplication of the HlyB protein. The hydropathy profiles of the two 
proteins are similar and reveal an extensive transmembrane region resembling those found in pore-forming plasma membrane proteins. The C-terminal region of P-glycoprotein and the HlyB protein contain sequences homologous to the nucleotide-binding domains of a group of closely related bacterial ATP-binding proteins $(68,69)$.

Both P-glycoprotein and HlyB transporter have a large hydrophobic region with 12 and 6 transmembrane (TMS) segments, respectively, which have channel-forming functions that act like flippase. The inhibition of the plasmid encoded haemolysin transporter HlyB can serve as a model for the inhibition of P-glycoprotein mediated drug efflux (70).

\section{Functions of ABC-transporters in normal tissues and in tumour cells}

In tumour cell lines, multidrug resistance is often associated with an ATP-dependent decrease in cellular drug accumulation which is attributed to the overexpression of certain ATPbinding cassette $(\mathrm{ABC})$ transporter proteins $(72,73)$. ABC proteins that confer drug resistance include (but are not limited to) P-glycoprotein (gene symbol $A B C B 1$ ) (74), the multidrug resistance protein 1 (MRP1, gene symbol $A B C C 1$ ) (75), MRP2 (gene symbol $A B C C 2$ ) (74), and the breast cancer resistance protein (BCRP, gene symbol ABCG2). P-glycoprotein, MRP1, MRP2, and BCRP/ABCG2 (76) are expressed in tissues important for absorption (e.g., lung and gut) and metabolism and elimination of compounds (liver and kidney). In addition, these transporters have an important role in maintaining the barrier function of sanctuary site tissues (e.g., blood-brain barrier, blood-cerebral spinal fluid barrier, bloodtestis barrier, adrenal gland and the maternal-fetal barrier or placenta) $(74,78,79,80)$.

\section{Structure and function of P-glycoprotein in cancer cells}

Structurally, the human $170 \mathrm{kDa}$ P-gp consists of 1280 amino acids residues forming two transmembrane domains (TMD) and two nucleotide-binding domains (NBD). The ABCATPase (NBD) domain has two short peptide motifs, a glycine-rich Walker-A and a hydrophobic Walker B motif. A third consensus sequence is named $\mathrm{ABC}$ signature $(82,84)$.

Figure 5. A hypothetical twodimensional model of human Pglycoprotein (P-gp) based on hydropathy analysis of the amino acid sequence and its functional domains.

(Figure taken from Ambudkar SV, Dey $\mathrm{S}$, Hrycyna CA et al. Biochemical, cellular and pharmacological aspects of the multidrug transporter. Annu. Rev.

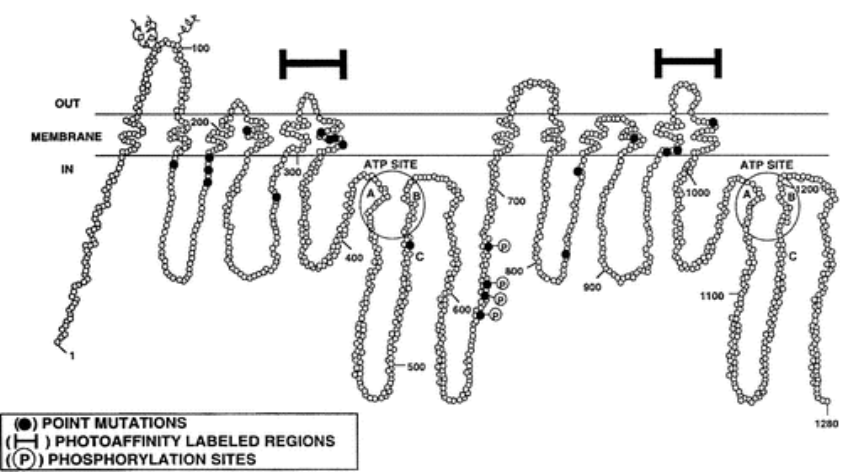
Pharmacol. Toxicol. 39:361-98, 1999) 
P-gp confers resistance against a wide spectrum of compounds that are hydrophobic, amphipathic natural product drugs. These compounds include not only anticancer drugs, but also therapeutic agents such as HIV-protease inhibitors. These compounds are chemically diverse, some of them may carry a positive charge at physiological $\mathrm{pH}$ and, because all are hydrophobic, they enter cells by passive diffusion (85).

The following selected compounds act as MDR substrates $(81,84)$ : anticancer drugs (vinca alcaloids), cytotoxic agents (ethidium bromide, colchicine), Gramicidin D, HIV protease inhibitors (Saquinavir), rhodamine 123.

„Classical” MDR modulators are calcium channel blockers (verapamil, nifedipine, azidopine, dihydropyridines); calmodulin antagonists (trifluoperazine, chlorpromazine) immunosuppressive agents (cyclosporin A and PSC833); antiarrhytmics (quinine, quinidine); antihypertensives (reserpine, yohimbine); antibiotics (hydrophobic cephalosporines); steroid hormones and derivatives (progesterone, tamoxifen) $(81,84)$.

\section{The background of the thesis: from antiplasmid effect to multidrug resistance reversal}

Lactose fermentation of E. coli or haemolysin B transporter expressed by the plasmids that carry these respective genes could be obviated by heterocyclic compounds that readily bind to plasmid DNA (70). An other way for plasmid elimination could be the thymine starvation which increased the frequency of R-plasmid elimination (71). These compounds could also reverse antibiotic resistance of E. coli, Enterobacter, Proteus, Staphylococcus and Yersinia strains by eliminating plasmids $(87,88,89)$. However, the frequency of this effect was significantly less than expected based on complex interaction with plasmid DNA (89). Bacterial plasmids can be eliminated from bacterial species grown as pure or mixed bacterial cultures in the presence of sub-inhibitory concentrations of non-mutagenic heterocyclic compounds (90,VII).

Inhibition of plasmid replication at various stages, shown in rolling circle model (replication, partition, conjugal transfer) may be the theoretical basis for the elimination of bacterial virulence in case of plasmid mediated pathogenicity and antibiotic resistance $(93,94)$. In addition, agents such as promethazine and acridine orange which have these activities have also been shown to reverse antibiotic resistance of various bacterial species, when were applied as controls $(86,95,96)$.

The inhibition of plasmid replication resulted in a single nick, outside of the replication origo of the superhelical structure. The process leads to further relaxation of plasmid DNA. The intercalations of the compounds were proved by the increase in melting 
point of the DNA and circular dichroism (98). The plasmid replication can also be inhibited by blocking of the activity of enzyme DNA-gyrase (97). In this case the introduction of superhelical turns into plasmid DNA is prevented. The activity of DNA gyrase isolated from M. luteus was inhibited in the presence of promethazine and imipramine (96) having plasmid curing effects. Apart from the general intercalation into dsDNA, a specific binding site for phenothiazine intercalation was found at the GC-rich region $(100,101)$. That means that the expression of GC rich promoter of MDR-1 gene responsible for drug resistance of cancer cells can be blocked simultaneously.

The antiplasmid compounds were able to inhibit also the plasmid transfer $(88,103)$. A dose dependent inhibition of conjugal plasmid transfer was observed (94) where both the transconjugal DNA synthesis and the mating pair formations themselves were inhibited. The inactivation of sex pili was proved by the inhibition of absorption of pilus specific phage $(86,103)$.

The adhesion of urinary pathogen $E$. coli strains were inhibited to HEP2 tissue culture cells by inhibition the adhesive, type I and p-fimbriae (104). Based on these results the synergistic effect of promethazine with gentamycine was studied in children, in frequently recurring pyelonephritis $(105)$ and in adults $(107,108)$. In these experiments 10 children were given a combination of gentamycin and promethazine for 7 days (Group 1). In the second group 11 children received gentamycin alone and in the $3^{\text {rd }}$ group 19 children were on longterm oral antibiotic prophylaxis with episodes of intensive treatment recurrences. In a 3year follow up period, the number of pyelonephritis recurrences was significantly lower in Group1 than in Groups 2 and 3.

The plasmid elimination was also studied in other experiment "in vivo" or ex vivo, when the plasmid profile of freshly isolated colonies from the urine of promethazine and imipramine treated adult patients from the Department of Urology were compared $(89,105)$. The in vitro effective concentrations of plasmid curing compounds were higher than the achievable serum concentration in the patients, consequently the frequency of in vivo plasmid curing was low as demonstrated, however the number of bacteria was much lower. The synergism between antibiotics and antiplasmid effect can be produced by complex mechanisms. 


\section{AIMS OF THE STUDY}

This study is focused on multidrug resistance to existing antibiotics and chemotherapeutics, which often leads to failures in the treatment of bacterial infections and cancer. There is an urgent need for strategies to overcome resistance and this research field includes many challenges from the perspective of chemistry and biology. The main points of the thesis are focused on the reversal of multidrug resistance in bacteria and tumour cells.

The goals of my study are the following:

\section{Antimicrobial effect of tricyclic compounds}

Before studying the resistance reversal effect of tricyclic compounds, their antimicrobial effects were investigated, the antibacterial effect of known antiplasmid compounds such as promethazine, trifluoperazine and 9-aminoacridine were studied on various bacterial strains. The attention was focused on the determination of the minimal inhibitory concentrations of the tricyclic compounds.

\section{Plasmid elimination by tricyclic compounds}

Plasmid curing effects of promethazine, trifluoroperazine, 9-aminoacridine were studied at sub-inhibitory concentration on laboratory strain of E. coli F'lac K12LE140 and doxycycline resistant clinical isolates of $E$. coli.

\section{Interactions of antiplasmid compounds with plasmid DNA}

1. Clarification of the mechanism of action of different chemicals, antiplasmid compounds on model nucleic acids such as calf thymus DNA and plasmid DNA by using thermal denaturation studies, UV spectral shifts and binding affinity determination

2. Complex formation of antiplasmid compounds with the isolated plasmid DNA from clinical strains by agarose gel electrophoresis

3. Identification of $\mathrm{Tc}^{\mathrm{r}}$ plasmid by isolation and retransfer from clinical isolate of $E$. coli

\section{The effect of proton pump inhibitor (1-(2-benzoxazolyl)-3,3,3-trifluoro-2-propanone}

\section{[TF18]) on the action of resistance modifiers in model experiments}

1. Interaction between proton pump inhibitor and antiplasmid compounds from the aspect of antibacterial effect: The effect of antiplasmid compounds combined with proton pump inhibitor was studied by checkerboard microdilution method. The type of interaction of 
promethazine, trifluoperazine and 9-aminoacridine was studied with the proton pump inhibitor 1-(2-benzoxazolyl)-3,3,3-trifluoro-2-propanone (TF18) from the aspect of antibacterial effect. In these studies E. coli K12 LE140 F'lac strain served as a model strain and an E. coli tetracycline resistant clinical isolate was used. The type of drug interactions was evaluated as synergism, additivity, indifference or antagonism.

2. Interaction between proton pump inhibitor and antiplasmid compounds from the aspect of antiplasmid effect: The plasmid curing effects of antiplasmid compounds (promethazine, trifluoroperazine, 9-aminoacridine) were investigated in the presence of proton pump inhibitor on E. coli F'lac K12LE140 and doxycycline resistant clinical strains to modify or improve the antiplasmid effect of these compounds.

3. Specific effect of proton pump inhibitor on a model of Helicobacter pylori: antibacterial and antimotility studies: The effect of proton pump inhibitor 1-(2benzoxazolyl)-3,3,3-trifluoro-2-propanone (TF18) was studied in combination with clarithromycin from the aspect of antibacterial effect and motility of Helicobacter pylori. The antimotility effect on Helicobacter pylori was evaluated based upon the determination of swimming, tumbling and non-motile cells under phase contrast microscopy.

\section{Reversal of multidrug resistance of mouse lymphoma cells with synthetic and plant derived compounds}

Based on the similarities of $\mathrm{ABC}$ transporters in bacterial and cancer cells the resistance reversal effects of different compounds were studied on P-glycoprotein mediated drug efflux on MDR tumour cells in vitro. In these experiments synthetic (benzonaphthyridine, pyrido[3,2-g]quinoline, pregnane and aza-oxafluorene derivatives) and plant derived compounds (coumarin derivatives, persimmon (Diospyros kaki) peel extracts, Indian tea leaves, Indian coffee seeds and chicory extracts) were investigated using drug accumulation assay with mouse lymphoma cells transfected with the human MDR1 gene.

\section{Apoptosis induction of resistance modifiers on mouse lymphoma cells}

As an alternative to antiproliferative effect, the apoptosis inducing action of some resistance modifiers was studied on tumour cells in the presence of cycloartanes. 


\section{MATERIALS AND METHODS}

\section{Compounds studied}

Phenothiazines: Pipolphen ${ }^{\circledR}$ (promethazine) [PMZ] (EGIS Pharmaceutical Company, Budapest, Hungary), Trifluoperazine dihydrochloride [TFP] (SIGMA Chemical Co., St.Louis, USA) (See Appendix 1.)

Acridines: 9-Aminoacridine hydrochloride monohydrate, 98\% [9AA] (Aldrich-Chemie, D7924 Steinheim), Acridine-orange (Reanal, Budapest, Hungary) (See Appendix 2.)

Trifluoroketones: 1-(2-benzoxazolyl)-3,3,3-trifluoro-2-propanone [TF18] were kindly provided by Professor Masami Kawase, Josai University, Japan (See Appendix 3.)

Antiarrhytmics: Verapamil (Chinoin, Budapest, Hungary) (See Appendix 4.)

Benzonaphthyridines were kindly provided by Prof. Jacques Barbe, Faculte de Pharmacie, Universite de la Mediterranee, Marseille (See Appendix 5.)

Pyrido[3,2-g]quinolines were kindly provided by Prof. Jacques Barbe, Faculte de Pharmacie, Universite de la Mediterranee, Marseille (See Appendix 7.)

Aza-oxafluorenes were kindly provided by Dr. Andreas Hilgeroth, Faculty of Pharmacy, Martin-Luther University, Halle (See Appendix 8.)

Pregnanes: Pregnane thioethers: P-S1Be, P-S1cHe; Pregnane sulphoxides: P-S2Be, P-S2cHe; Pregnane sulphones: P-S3Be, P-S3cHe provided by Dr. János Kiss, Department of Organic Chemistry, University of Szeged (See Appendix 6.)

Persimmon (Diospyros kaki) peel extracts (III)

Indian tea leaves, Indian coffee seeds and chicory extracts (II)

Coumarin derivatives were kindly provided by Prof. Masami Kawase, Josai University, Japan (See Appendix 7.)

Cycloartanes isolated from Euphorbia species were kindly provided by Prof. Maria-José U. Ferreira, Universidade Nova de Lisboa, Portugal (See Appendix 8.)

\section{Chemicals}

Antibiotics: clarithromycin (Klacid ${ }^{\circledR}$ ) was purchased from Abbott, doxycycline (Chinoin Pharmaceutical Company, Budapest, Hungary)

Dye: 3-(4,5-dimethythiazol-2-yl)-2,5-diphenyltetrazolium bromide (MTT) (Sigma)

Bacterial strains. The following bacterial strains resistant to two or more antibiotics (multidrug resistant) were isolated from patients and employed in this study: E. coli 34439 (resistant to ampicillin, doxycycline), E. coli 34253 (resistant to doxycycline), Enterobacter cloacae 44937 (resistant to ampicillin, amoxicillin/clavulanic acid, unasyn, cefuroxime, ceftazidime, ceftriaxone, cefotaxime, piperacillin/tazobactam, cefamandole, intermediately susceptible to doxycycline), $\boldsymbol{E}$. coli 42559 (resistant to ampicillin and doxycycline), $\boldsymbol{E}$. coli 34613 (resistant to ampicillin and doxycycline), E. coli 34561 (resistant to ampicillin, doxycycline and sumetrolim), $\boldsymbol{E}$. coli $\mathbf{4 2 8 8 3}$ (resistant to ampicillin, doxycycline and sumetrolim), E. coli 42891 (resistant to ampicillin, doxycycline and ciprofloxacin), $\boldsymbol{E}$. coli 30906 (resistant to ampicillin, doxycycline, ofloxacine and ciprofloxacin), Citrobacter freundii 47051 (resistant to ampicillin, amoxicillin/clavulanic acid, unasyn, cefuroxime, sumetrolim, gentamicin, tobramycin, amikacin, netilmicin, ceftazidime, ceftriaxone, cefotaxime, ceftibutem, cefixime, cefamandole, intermediately susceptible to ofloxacin and doxycycline). The strains were provided by Dr. Edit Hajdú (Institute of Clinical Microbiology and Diagnostics, University of Szeged).

Escherichia coli K12 LE $140\left(\mathrm{~T}_{6}{ }^{\mathrm{r}}, \mathrm{T}_{1}^{\mathrm{s}}, \mathrm{Sm}^{\mathrm{R}}, \mathrm{lac}^{-} \mathrm{D}, \mathrm{Su}^{-}, \lambda^{\mathrm{R}}, \mathrm{Mal}^{-}\right)$characterized and maintained in our laboratory served as a control strain.

Escherichia coli DH5 $\alpha\left(\right.$ deo $\mathrm{R}$, end $\mathrm{A} 1$, gyrA96, hsd $\mathrm{R} 17\left(\mathrm{r}_{\mathrm{k}}{ }^{-} \mathrm{m}_{\mathrm{k}}{ }^{+}\right)$, recA1, relA1, sup E44, thi-1, $\Delta($ lacZYA-argFV169), Ф80lacZAM15, F $)$ 
Helicobacter pylori ATCC 700392 (clarithromycin susceptible) and Helicobacter pylori

9447 (clarithromycin resistant, from the stock collection of the Institute of Medical

Microbiology and Immunobiology)

Cell cultures: The L5178Y parent mouse T cell lymphoma cell line and its human MDR-1 gene transfected subline L5178 were maintained in McCoy's 5A medium supplemented with $10 \%$ heat inactivated horse serum, L-glutamine and antibiotics. Media for cell line cultivation: McCoy's 5A medium modified (Gibco BRL) $(111,112)$

Culture media for bacteria: MTY (trypton-yeast extract) liquid media and MTY agar plates (110); EMB (eosin-methylene blue, bioMérieux) agar were used for the differentiation of lac negative (lac-) and lac positive (lac+) colonies; LB (Luria Bertani) broth and LB agar plates; BHI broth brain heart infusion broth (Merck); Columbia blood agar: both $H$. pylori strains were maintained on Columbia blood agar plates (Biolab) with 5\% defibrinated sheep blood. For the culturing of the clarithromycin resistant $H$. pylori 9447 strain the media was supplemented with $2 \mathrm{mg} / \mathrm{L}$ clarithromycin. The bacterial cultures were grown at $37^{\circ} \mathrm{C}$ for 3 days under microaerophilic conditions by using anaerobic jar (Oxoid) with gas generating sachets (bioMérieux).

\section{Methods.}

\section{Detecting MIC values}

Overnight cultures of bacterial strains were diluted to $10^{-4}$ in $2 \mathrm{x}$ MTY broth, and transferred to 96 well microplate, then $50 \mu \mathrm{L}$ of various concentrations of promethazine, doxycycline, 9amino-acridine or trifluoperazine solutions were added to $50 \mu \mathrm{L}$ of bacterial dilutions. The microplates were incubated at $37^{\circ} \mathrm{C}$ for 24 hours, and then MIC values were determined. (113)

\section{Plasmid elimination on E.coli K12 LE140}

An overnight preculture of E. coli K12 LE140 was diluted to $10^{-4}$ and $1 \mathrm{~mL}$ aliquot was inoculated into $100 \mathrm{~mL}$ MTY broth. Various concentrations of TF $18(0.05-2 \mu \mathrm{g} / \mathrm{mL})$ and antiplasmid compounds (promethazine $60 \mu \mathrm{g} / \mathrm{mL}$, trifluoperazine $20 \mu \mathrm{g} / \mathrm{mL}$, 9-aminoacridine $5 \mu \mathrm{g} / \mathrm{mL}$ ) were added to $1 \mathrm{~mL}$ of the diluted cultures, and the samples were incubated at $37^{\circ} \mathrm{C}$ for 24 hours. Two dilutions $\left(10^{-4}\right.$ and $10^{-5}$ concentrations) were prepared from tubes showing growth and $100 \mu \mathrm{L}$ aliquots plated on EMB agar. The plates were incubated at $37^{\circ} \mathrm{C}$ for 24 hours, and then counted for pink (lac-) and deep violet (lac+) colonies. The percentage (\%) of plasmid elimination was determined.

\section{Replica plating}

Overnight precultures of bacterial strains were diluted to $10^{-4}$ and $1 \mathrm{~mL}$ aliquots inoculated into $100 \mathrm{~mL}$ of MTY broth. Various concentrations of promethazine and trifluoperazine were added to $5 \mathrm{~mL}$ of the diluted cultures, and were incubated at $37^{\circ} \mathrm{C}$ for 24 hours. In case of combination studies micro method was applied and in this case various concentrations of promethazin or trifluoperazine and other compounds (1-(2-benzoxazolyl)-3,3,3-trifluoro-2propanone [TF18] or verapamil) were added to $1 \mathrm{~mL}$ of the diluted cultures, and the samples were incubated at $37^{\circ} \mathrm{C}$ for 24 hours. Dilutions of $10^{-4}$ and $10^{-5}$ were prepared from tubes showing growth and plated as $100 \mu \mathrm{L}$ aliquots on MTY agar.

The plates were incubated at $37^{\circ} \mathrm{C}$ for 24 hours. The velvet replica from master plates were prepared onto plates containing doxycycline and after 24 hours incubation the master and replica plates were compared and the ratio of the plasmid elimination was determined (114).

Spectrophotometric methods for nucleic acids interactions (calf thymus DNA and pBR 322 plasmid DNA)

\section{Measurement of the thermal denaturation profiles of Ligand:}

DNA complexes were made for Ligand: Polynucleotide ratios of 1:10 and were recorded on a Cary Varian Model IE spectrophotometer using a Cary temperature controller connected to a Cary $1 / 3$ multicell block. The solutions were allowed to equilibrate for 20 minutes before 
increasing the temperature and the temperature then increased at a rate of $0.5^{\circ} \mathrm{C} /$ minute. A cell containing Polynucleotide solution alone was always measured along side cells containing Ligand/Polynucleotide mixtures to act as an internal standard. The blank cells in all measurements contained Tris buffer solution and all cells were stoppered with teflon caps, after debubbling and space was allowed for expansion of the solutions. The mid point of the thermal denaturation profile of the solutions $\left(\mathrm{T}_{\mathrm{m}}\right)$ was determined by calculating the average absorbance using the instruments thermal application software (3).

\section{Nucleic Acid Interactions: $U V$ spectral shifts and binding affinity determination}

In the case of the monosubstituted pyrido[3,2-g] quinolines: 4a, 4b, 4c and $4 d$ which all exhibit absorption maxima in the visible region well away from the absorption maxima of nucleic acids it was possible to investigate the interaction of these compounds with nucleic acids by UV spectral shift analysis. The spectra of a series of solutions of the monosubstituted pyrido[3,2-g] quinolines were measured in the presence of increasing amounts of either CT DNA or pBR322 plasmid DNA. The spectra were recorded on a Cary Varian 1E spectrophotometer in $0.03 \mathrm{M}$ Tris-buffer containing $0.018 \mathrm{M} \mathrm{NaCl}$ at $\mathrm{pH} 7.00$ for $2.50 \times 10^{-5} \mathrm{M}$. The bathochromic shift (if any) was determined and a binding affinity constant (k) calculated from the hypochromic shift recorded at the $\lambda_{\max }$ of each compound using the Grafit version 5 curve fitting software (Erithacus Software)

\section{Isolation and treatment of plasmid DNA}

The isolation of plasmid DNA was performed according to Birnboim and Doly (115). In case of treated plasmid DNA the following compounds were added to the extracted plasmid DNA: $5 \mu \mathrm{L}$ of promethazine (stock solution $1 \mathrm{mg} / \mathrm{mL}$ ) or $5 \mu \mathrm{L}$ of 9 -aminoacridine (stock solution 0.5 $\mathrm{mg} / \mathrm{mL}$ ) was added to the samples. The samples were incubated for 10 minutes at $37^{\circ} \mathrm{C}$.

\section{Detecting plasmid DNA by gel electrophoresis}

5-10 $\mu \mathrm{L}$ of RNase treated plasmid DNA solutions were applied to $0.7 \%$ agarose gel with 0.5 $\mu \mathrm{g} / \mathrm{mL}$ ethidium bromide. $2 \mu \mathrm{L}$ STOP buffer was added to the DNA samples $(10-10 \mu \mathrm{L}$ plasmid DNA) and promethazine was added to the plasmid DNA samples to final concentration of $0.3 \mu \mathrm{g} / \mathrm{mL}$, and 9-aminoacridine was added to the plasmid DNA to final concentration of $0.15 \mu \mathrm{g} / \mathrm{mL}$. The gel was run at $200 \mathrm{~V}$ for 45 minutes and the plasmid DNA fragments were detected by UV light.

\section{Isolation and retransfer of Tc $^{r}$ plasmid}

The Tc ${ }^{\mathrm{r}}$ plasmid isolation from E. coli 42883 was performed with the aid of the QIAprep Spin Miniprep Kit (QIAGEN GmbH, Germany) and retransformed into E. coli DH5 $\alpha$ cells. The competent DH5 $\alpha$ cells were transformed by the isolated DNA band after elution from the agarose gel.

\section{Experiments to investigate the interaction between antiplasmid compounds and proton pump inhibitor \\ Checkerboard microdilution assay}

The checkerboard method is the technique used most frequently to asses antibacterial combinations in vitro. The dilutions of the compounds were prepared in MTY broth for the antibacterial studies. The drug-containing solutions were distributed in 96-well-microtiter plates. The results of the combined use of antiplasmid compounds and TF18 were evaluated according to Eliopoulos and Moellering (116) such as synergism, additivity, indifference and antagonism. The bacterial strains E. coli F'lac K12 LE140 and the clinical strain E. coli 42883 were tested by the microdilution checkerboard technique. Briefly, bacterial dilutions from the logarithmic-growth phase were prepared and subsequently distributed into microtiter plates containing various drug concentrations. The final inoculum size was approximately $10^{4}$ colony forming units $(\mathrm{CFU}) / \mathrm{mL}$. The inoculated microtiter plates were incubated at $37^{\circ} \mathrm{C}$ for a period of 24 hours, and then the plates were stained with $20 \mu \mathrm{L}$ of MTT $(10 \mathrm{mg} / \mathrm{mL}$ stock 
solution), incubated for 6 hours and read for the inhibition of bacterial growth by using ELISA reader.

\section{Checkerboard method on Helicobacter pylori}

This microdilution method was used for determining the MIC values of TF18 and clarithromycin separately and in combination on H. pylori strains. A $10^{3}$ times dilution was prepared in brain heart infusion broth from a well grown 72 hours old bacterial culture then a checkerboard test was performed as described earlier. The microtiter plates were incubated at $37^{\circ} \mathrm{C}$ for 60 hours under micraerophilic conditions. After the incubation period MTT dye was used to make bacterial growth visible (116).

\section{Method for antimotility test with TF18}

A thick 3 days growth of $H$ pylori from Columbia blood agar plate was scraped into brain heart infusion broth (Merck), and was incubated at $37{ }^{\circ} \mathrm{C}$ for 22 hours under microaerophilic conditions in brain heart infusion broth. $100 \mu \mathrm{L}$ of the bacterial suspension was added to 100 $\mu \mathrm{L}$ of different dilutions of TF18 containing 10, 50, 90, $200 \%$ of MIC value. As a control PBS was used without the agent. After addition of the compound the samples were incubated for 5 minutes at $37{ }^{\circ} \mathrm{C}$, and then examined. $3 \mu \mathrm{L}$ of the sample was dropped onto a microscopic slide and was covered with a coverslip. The samples were examined under a phase contrast microscope (Zeiss) with 40x objective. Approximately 50 cells were counted from 6 fields. The number of swimming, tumbling and non-moving cells was counted separately on the screen of computer aided phase contrast microscope.

\section{Studies on human mdr1 gene transfected mouse lymphoma cells}

\section{Antiproliferative assay by MTT}

The effects of increasing concentrations of the drugs alone and their combinations with resistance modifiers on cell growth were tested in 96-well flat-bottomed microtitre plates. The compounds were diluted in a volume of $50 \mu \mathrm{L}$. Then, $1 \times 10^{4}$ cells in $0.1 \mathrm{~mL}$ of medium were added to each well, with the exception of the medium control wells. The culture plates were further incubated at $37{ }^{\circ} \mathrm{C}$ for $72 \mathrm{~h}$; at the end of the incubation period, $20 \mu \mathrm{L}$ of MTT solution (from a $5 \mathrm{mg} / \mathrm{mL}$ stock) was added to each well. After incubation at $37{ }^{\circ} \mathrm{C}$ for $4 \mathrm{~h}$, $100 \mu \mathrm{L}$ of SDS solution (10\%) was measured into each well and the plates were further incubated at $37{ }^{\circ} \mathrm{C}$ overnight. The cell growth was determined by measuring the optical density (OD) at $550 \mathrm{~nm}$ (ref. $630 \mathrm{~nm}$ ) with a Dynatech MRX vertical beam ELISA reader. Inhibition of cell growth (as a percentage) was determined according to the formula:

$100-\left[\frac{\text { OD sample-OD medium control }}{\text { ODcell control-OD medium control }}\right] \times 100$

\section{Inhibition of multidrug resistance by rhodamine 123 accumulation assay}

The harvested cells were resuspended in serum free McCoy's 5A medium and were distributed in $0.5 \mathrm{~mL}$ aliquots into Eppendorf tubes at the concentration of $2 \times 10^{6} \mathrm{cell} / \mathrm{mL}$. Then 2 and $20 \mu \mathrm{L}$ of the stock solution ( $1 \mathrm{mg} / \mathrm{mL}$ in DMSO) of the tested compounds were added and incubated for $10 \mathrm{~min}$ at room temperature. Then $10 \mu 1$ of rhodamine 123 was added to the samples (5.5 $\mu \mathrm{M}$ final concentration) and then the cells were further incubated for 20 $\min$ at $37^{\circ} \mathrm{C}$. The samples were washed twice in phosphate buffered saline (PBS) and $0.5 \mathrm{~mL}$ of the samples were prepared for analysis. The fluorescence uptake of the cells was measured by flow cytometer (Becton Dickinson FACScan). Verapamil was used as a positive control.

The fluorescence activity ratio was calculated as follows:

\section{Ratio $=($ MDR treated $/$ MDR control $) /($ PAR treated $/ P A R$ control $)$ Apoptosis induction by cycloartanes}

The assay was carried out according to the protocol of Alexis Biochemicals with little modification (118). The fluorescence activity (FL-1, FL-2) of the cells was measured and analysed on a Becton Dickinson FACScan instrument. 


\section{RESULTS}

\section{Antimicrobial effects of tricyclic compounds}

The antibacterial activity of compounds against the F'lac plasmid carrying model strain of $E$. coli K12LE140 is presented by Table 1. Tricyclic compounds such as two phenothiazines, promethazine and trifluoperazine and an acridine derivative, 9-aminoacridine were studied for their antibacterial effects.

Table 1. Minimal inhibitory concentrations of antiplasmid compounds and on E. coli F'lac K12LE140 and doxycycline resistant clinical isolates of E. coli, Enterobacter cloacae and Citrobacter freundii

\begin{tabular}{||l|l|l|l|l||}
\hline & \multicolumn{4}{|c|}{ MIC $\boldsymbol{\mu g} / \mathbf{m L}$} \\
\hline Strains & PMZ & TFP & 9-AA & Doxycycline \\
\hline E. coli F'lac K12 LE140 & 125 & 62.5 & 7.8 & $<0.24$ \\
\hline E. coli 42883 & 85 & 30 & 12 & 62 \\
\hline E. coli34253 & 85 & 30 & 13 & 62 \\
\hline E. coli34439 & 95 & 30 & 9 & 31 \\
\hline E. coli30906 & 95 & 30 & 9 & 120 \\
\hline E. coli34613 & 95 & 30 & 10 & 31 \\
\hline E. coli42559 & 105 & 40 & 12 & 125 \\
\hline Enterobacter cloacae 44937 & 115 & 80 & 15 & 7.5 \\
\hline E. coli34561 & 125 & 30 & 10 & 31 \\
\hline E. coli 42891 & 125 & 60 & 10 & 62 \\
\hline Citrobacter freundii 47051 & 125 & 100 & 15 & 7.5 \\
\hline
\end{tabular}

MIC values are essential data to design plasmid curing experiments for different bacterial strains because the plasmid elimination of compounds occurs only at sub-inhibitory concentrations of the respective agents. The use of sub-inhibitory concentrations allows the growth of the bacterium sub-optimally as one of the required conditions for the demonstration of plasmid elimination because plasmid replication is dependent upon bacterial replication and the number of subsequent generations.

\section{Plasmid elimination by tricyclic compounds}

\section{Plasmid curing experiments for F'lac plasmid elimination}

After incubation of the bacterium carrying the lac plasmid with sub-inhibitory concentrations of the agents, aliquots of the dilution of the culture are streaked on drug-free medium 
containing eosin-methylene blue (EMB). The EMB reagent allows the identification of colonies that contain or lack the lac plasmid, by the colours deep violet (lac ${ }^{+}$) or pink $\left(\mathrm{lac}^{-}\right)$, respectively (Figure 8). The per cent of plasmid elimination (curing) is determined by the number of pink colonies divided by the total number of colonies (pink and deep violet) grown on the surface of the agar plate. The plasmid curing compounds showed their antiplasmid effect at sub-inhibitory concentrations: the ratio of plasmid elimination of promethazine was $65.83 \%$ at $60 \mu \mathrm{g} / \mathrm{mL}$; for trifluoperazine the most effective concentration for plasmid elimination was $20 \mu \mathrm{g} / \mathrm{mL}$, the frequency of plasmidfree colonies was $10.52 \%$; 9aminoacridine eliminated the F'lac plasmid at $5 \mu \mathrm{g} / \mathrm{mL}$ concentration with $53.74 \%$ frequency (Table 2).

Table 2. Plasmid elimination on E. coli F'lac K12 LE140 in the presence of promethazine, trifluoperazine and 9-aminoacridine

\begin{tabular}{|c|c|c|c|c|c|c|c|c|c|}
\hline & & Number & colony fo & ners & $\begin{array}{l}\text { Plasm } \\
\text { elimin }\end{array}$ & $\begin{array}{l}\text { d } \\
\text { tion } \%\end{array}$ & & Mean & $S D$ \\
\hline & $\mu \mathrm{g} / \mathrm{mL}$ & Exp1 & Exp2 & Exp3 & Exp1 & Exp2 & Exp3 & & \\
\hline Control & 0 & $1.6 \times 10^{8}$ & $2.3 \times 10^{8}$ & $2.5 \times 10^{8}$ & 0 & 0 & 0 & 0 & 0 \\
\hline PMZ & 10 & $1.5 \times 10^{8}$ & $2.8 \times 10^{8}$ & $2.3 \times 10^{8}$ & 0 & 0.3 & 0 & 0 & 0 \\
\hline & 20 & $8.5 \times 10^{7}$ & $1.9 \times 10^{7}$ & $1.3 \times 10^{8}$ & 0 & 0 & 0.1 & 0,03 & 0.06 \\
\hline & 40 & $5.1 \times 10^{7}$ & $1.2 \times 10^{7}$ & $2.4 \times 10^{7}$ & 0.78 & 4.76 & 1.41 & 2.32 & 2.14 \\
\hline & 60 & $2.1 \times 10^{7}$ & $1.1 \times 10^{7}$ & $5.6 \times 10^{7}$ & 56.42 & 68.67 & 72.41 & 65.83 & 8.36 \\
\hline & 80 & $2.0 \times 10^{7}$ & $7.8 \times 10^{6}$ & $6.2 \times 10^{6}$ & 43.69 & 46.15 & 53.03 & 47.62 & 4.84 \\
\hline & 100 & MIC & $M I C$ & $M I C$ & & & & & \\
\hline TFP & 10 & $7.6 \times 10^{8}$ & $2.7 \times 10^{8}$ & $5.6 \times 10^{8}$ & 0 & 0 & 0 & 0 & 0 \\
\hline & 20 & $1.8 \times 10^{8}$ & $1.7 \times 10^{8}$ & $1.3 \times 10^{8}$ & 7.37 & 8.4 & 15.8 & 10.52 & 4.59 \\
\hline & 30 & $1.5 \times 10^{8}$ & $2.2 \times 10^{8}$ & $1.1 \times 10^{8}$ & 0 & 0,4 & 0 & 0.13 & 0.23 \\
\hline & 40 & $8.1 \times 10^{7}$ & $1.4 \times 10^{8}$ & $5.2 \times 10^{7}$ & 0 & 0 & 0 & 0 & 0 \\
\hline & 50 & MIC & $M I C$ & $M I C$ & & & & & \\
\hline 9-AA & 3 & $2.2 \times 10^{8}$ & $2.4 \times 10^{8}$ & $3.4 \times 10^{8}$ & 0 & 0 & 0 & 0 & 0 \\
\hline & 4 & $4.9 \times 10^{7}$ & $6.8 \times 10^{7}$ & $1.2 \times 10^{7}$ & 2.94 & 2.04 & 11.11 & 5.36 & 4.99 \\
\hline & 5 & $5.2 \times 10^{7}$ & $5.9 \times 10^{7}$ & $2.2 \times 10^{7}$ & 61.52 & 57.14 & \begin{tabular}{|l|}
42.57 \\
\end{tabular} & 53.74 & 9.92 \\
\hline & 6 & $2.6 \times 10^{7}$ & $1.2 \times 10^{7}$ & $1.8 \times 10^{6}$ & 2.1 & 3.2 & 0 & 1.77 & 1.62 \\
\hline & 7 & $1 \times 10^{6}$ & $1 \times 10^{6}$ & $1 \times 10^{6}$ & 0 & 0 & 0 & 0 & 0 \\
\hline & 8 & MIC & $M I C$ & $M I C$ & & & & & \\
\hline
\end{tabular}




\section{Plasmid curing experiments for elimination of doxycycline resistance}

In this study the plasmid curing activity of promethazine and trifluoperazine was measured on doxycycline resistance of clinical isolates in three independent experiments, marked as Expl, Exp2 and Exp3 (Figure 8). After testing the ten strains, the frequency of plasmid curing and elimination of tetracycline resistance was low for the majority of strains. The doxycycline resistance could not be eliminated from E. coli 42891 and 34439 strains, furthermore the plasmid elimination was ineffective in case of Citrobacter freundii and Enterobacter cloacae as well (data not shown). The next four strains, E. coli 30906, 34253, 34613, 42559 showed very low frequency of plasmid elimination, the efficacy of plasmid elimination varied between 0 and $7.3 \%$ expressed in the percentage of plasmidfree colonies (Table 3.A., 3.B., 3.D.). The highest frequency of plasmid curing has been observed in two E. coli strains such as E. coli 34561 and E. coli 42883 (Table 3.C., 3.E).

After 24 hours incubation with phenothiazines on E. coli 34561, the plasmid curing activity proved $14.67 \%$ at $10 \mu \mathrm{g} / \mathrm{mL}$ PMZ and at $20 \mu \mathrm{g} / \mathrm{mL}$ TFP the frequency of plasmid curing was $10.23 \%$ (Table 3.C.). The investigated phenothiazines exerted the highest antiplasmid activity on E. coli 42883 (Table 3.E.). At $90 \mu \mathrm{g} / \mathrm{mL}$ promethazine the plasmid curing activity $(27.6 \%)$ could be explained as remarkable antiplasmid effect similar to trifluoperazine, which exerted $26.23 \%$ antiplasmid effect at $10 \mu \mathrm{g} / \mathrm{mL}$ (IV).

Table 3.A.-3.D. Plasmid elimination on clinical isolates in the presence of promethazine and trifluoperazine (mean of 3 independent experiments)

\begin{tabular}{|c|c|c|c|c|c|}
\hline & \multicolumn{2}{|l|}{ A)E.coli 30906} & \multicolumn{2}{|l|}{ B) E.coli 34253} \\
\hline & & $\begin{array}{l}\text { Plasmid elimination\% } \\
\text { (Mean) }^{*}\end{array}$ & SD & $\begin{array}{l}\text { Plasmid elimination\% } \\
\text { (Mean)* }\end{array}$ & SD \\
\hline \multicolumn{2}{|c|}{$\begin{array}{l}\text { concentration } \\
\mu \mathrm{g} / \mathrm{mL}\end{array}$} & \multicolumn{2}{|c|}{$\begin{array}{l}\text { *after replica plating onto doxycycline } \\
\text { containing MTY plates } \\
(100 \mu \mathrm{\mu g} / \mathrm{mL} \text { doxycycline/plate) }\end{array}$} & $\begin{array}{l}\text { *after replica plating onto doxycycline } \\
\text { containing MTY plates }(50 \mu \mathrm{g} / \mathrm{mL} \\
\text { doxycycline/plate) }\end{array}$ & \\
\hline control & 0 & 0 & 0 & 0 & 0 \\
\hline \multirow[t]{6}{*}{ PMZ } & 10 & 3.67 & 0.49 & 1.15 & 1.99 \\
\hline & 30 & 1.57 & 1.38 & 0 & 0 \\
\hline & 50 & 0 & 0 & 0 & 0 \\
\hline & 70 & 0 & 0 & 0 & 0 \\
\hline & 90 & 0 & 0 & 0 & 0 \\
\hline & 100 & $M I C$ & & $M I C$ & \\
\hline \multirow[t]{9}{*}{ TFP } & 10 & 0 & 0 & 3 & 2.65 \\
\hline & 20 & 0 & 0 & 0 & 0 \\
\hline & 30 & 0 & 0 & 0 & 0 \\
\hline & 40 & 0 & 0 & 0 & 0 \\
\hline & 50 & 0 & 0 & $M I C$ & \\
\hline & 60 & 0 & 0 & & \\
\hline & 70 & 0 & 0 & & \\
\hline & 80 & 0 & 0 & & \\
\hline & 90 & $M I C$ & & & \\
\hline
\end{tabular}




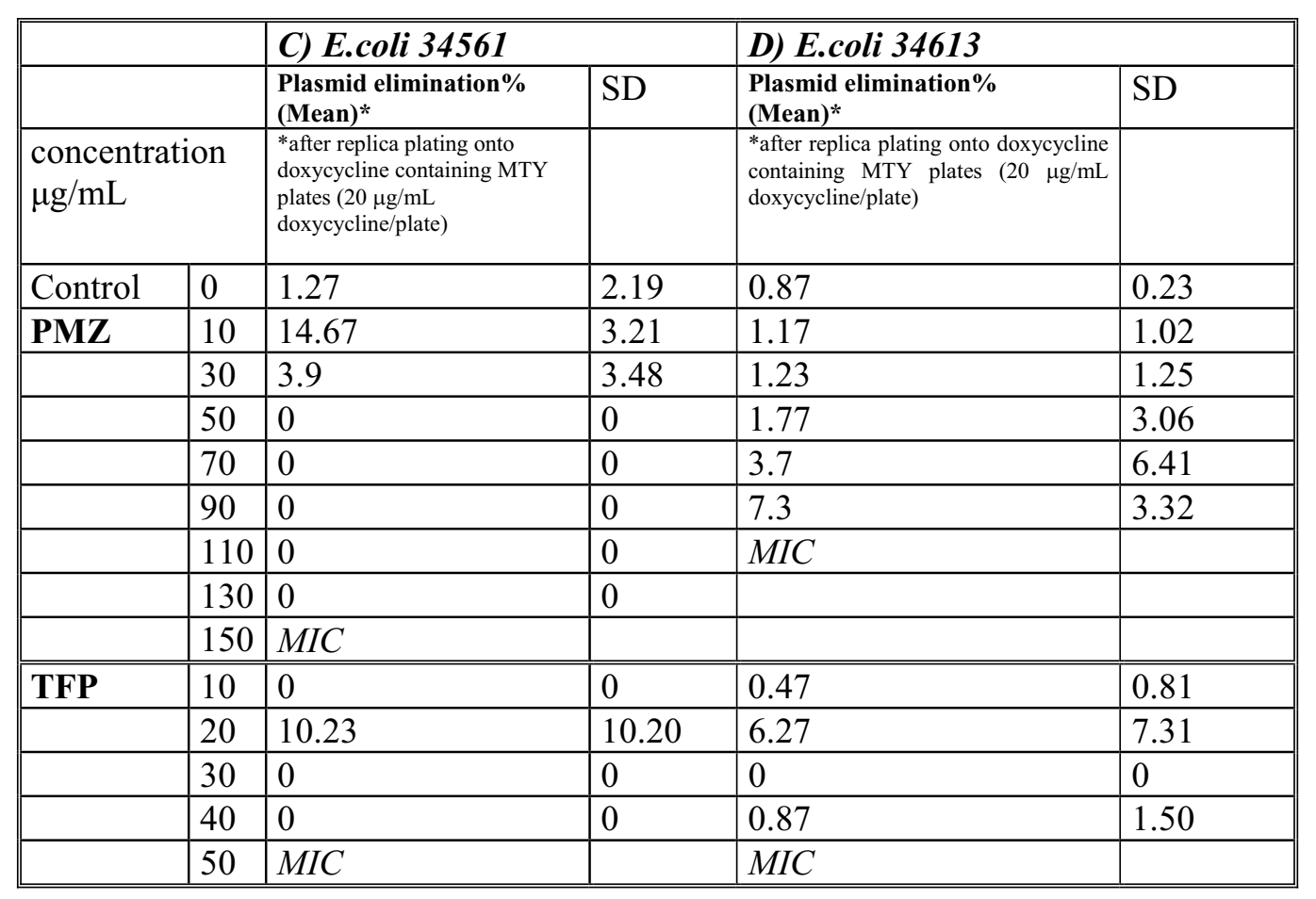

Table 3.E. Plasmid elimination on E. coli 42883 in the presence of promethazine and trifluoperazine

\begin{tabular}{|l|l|l|l|l|l|l|l|l|l||}
\hline E.coli 42883 & \multicolumn{2}{l}{$\begin{array}{l}\text { Number of colony formers } \\
\text { cfu/mL }\end{array}$} & \multicolumn{2}{l|}{ Plasmid elimination\%* } & Mean & SD \\
\hline concentration $\mu \mathrm{g} / \mathrm{mL}$ & Exp1 & Exp2 & Exp3 & Exp1 & Exp2 & Exp3 & & \\
\hline Control & 0 & $5 \times 10^{8}$ & $7.6 \times 10^{8}$ & $1.7 \times 10^{9}$ & 0 & 0 & 0 & 0 & 0 \\
\hline PMZ & 10 & $3.1 \times 10^{8}$ & $9.1 \times 10^{8}$ & $1 \times 10^{9}$ & 9.7 & 0 & 1.9 & 3.87 & 5.14 \\
\hline & 30 & $7.1 \times 10^{8}$ & $2.4 \times 10^{9}$ & $4.3 \times 10^{8}$ & 0 & 2 & 0 & 0.67 & 1.15 \\
\hline & 50 & $5.5 \times 10^{8}$ & $5.5 \times 10^{8}$ & $2.3 \times 10^{8}$ & 1.8 & 1.8 & 0 & 1.2 & 1.04 \\
\hline & 70 & $2.2 \times 10^{8}$ & $2.4 \times 10^{8}$ & $2.5 \times 10^{7}$ & 0 & 4.2 & 12 & 5.4 & 6.09 \\
\hline & 90 & $5.4 \times 10^{7}$ & $1.8 \times 10^{7}$ & $1.3 \times 10^{8}$ & 48.1 & 27.8 & 6.9 & 27.6 & 20.60 \\
\hline & 110 & $3 \times 10^{6}$ & $4.4 \times 10^{7}$ & $M I C$ & 0 & 0.7 & & 0.35 & 0.49 \\
\hline & 120 & $M I C$ & $M I C$ & & & & & & \\
\hline TFP & 10 & $1.1 \times 10^{9}$ & $3.2 \times 10^{8}$ & $8 \times 10^{8}$ & 46.8 & 15.6 & 16.3 & 26.23 & 17.81 \\
\hline & 30 & $3 \times 10^{8}$ & $8 \times 10^{7}$ & $1.4 \times 10^{8}$ & 10 & 12.5 & 25 & 15.83 & 8.04 \\
\hline & 50 & $1.7 \times 10^{8}$ & $1.8 \times 10^{7}$ & $3.6 \times 10^{8}$ & 8.2 & 0 & 2.8 & 3.67 & 4.17 \\
\hline & 60 & $M I C$ & $M I C$ & $M I C$ & & & & & \\
\hline
\end{tabular}

*after replica plating onto doxycycline containing MTY plates $(125 \mu \mathrm{g} / \mathrm{mL}$ doxycycline/plate $)$

\section{Interactions of antiplasmid compounds with plasmid DNA}

A possible explanation of antiplasmid effect can be the direct interaction with DNA, therefore physico-chemical studies such as thermal stability studies were carried out with various resistance modifiers.

\section{Clarification of the mechanism of action of different chemicals, antiplasmid compounds on model nucleic acids}

It is well known that the denaturation of nucleic acids caused by elevated temperature will increase their UV absorbance due to the melting of double stranded regions 
(hyperchromic effect). By measuring the UV absorbance of nucleic acids at increasing temperature, the melting of nucleic acids can be monitored and the phase-transition temperature $\left(T_{m}\right)$ can be determined. Both positive and negative changes in $T_{m}$ values can occur: an increase in $T_{m}$ indicates stabilisation of the DNA helix and a decrease in $T_{m}$ can mean the degradation of the nucleic acid by different chemical agents.

In order to confirm the evidence of the binding of antiplasmid compounds to nucleic acids the UV spectrum of the ligands can be examined. When a ligand possessing a chromophore binds to nucleic acids, its UV spectra will be altered as a consequence of changes in its molecular environment. The wavelength of absorption undergoes a shift to longer wavelengths (bathochromic shift) with corresponding decrease in absorbance (hypochromic shift) which is a good indication of an interaction between the ligand and the nucleic acid.

Pyrido[3,2-g] quinoline derivatives: All 4 compounds raised the denaturation temperature of calf thymus DNA and plasmid DNA (Table 4). The increases in Tm, compared with the reference compounds 9-aminoacridine and acridine orange, indicate that all 4 compounds interact strongly with calf thymus DNA and pBR 322 plasmid DNA. The results may be compared to the standard compounds, 9-aminoacridine, acridine orange, promethazine and trifluoperazine. All 4 compounds showed a bathochromic and hypochromic shift in the presence of calf thymus DNA indicating intercalation into DNA (IX).

Pregnanes: An analysis of the results in Table 4 shows the effect of pregnane derivatives on the $\mathrm{T}_{\mathrm{m}}$ of various nucleic acids. Largely negative $\Delta \mathrm{T}_{\mathrm{m}}$ values are observed indicating a greater affinity for single-stranded forms of the nucleic acid. The variations in $\mathrm{T}_{\mathrm{m}}$ produced both positive and negative are relatively small $\left( \pm 2^{\circ}\right)$ in the case of both calf thymus and plasmid DNA (IX). Aza-fluorenes: The 3 compounds investigated showed only marginal interaction with calf thymus DNA but a slightly increased interaction with plasmid DNA (Table 4) (IX). 
Table 4. Changes in thermal stability, thermal denaturation temperature $\left(T_{m}\right)$ of calf thymus DNA, pBR 322 plasmid DNA in the presence of acridine derivatives, phenothiazines, pyrido[3,2-g] quinoline derivatives, pregnanes and aza-oxafluorene derivatives.

\begin{tabular}{|l|c|c|}
\hline Compound & Calf thymus DNA & Plasmid DNA \\
\hline Untreated controls & Tm $=60.0$ & Tm $=50.4$ \\
\hline Acridines & & delta Tm \\
\hline 9-Aminoacridine & 10.70 & 12.00 \\
\hline Acridine Orange & 12.60 & 9.60 \\
\hline Phenothiazines & & \\
\hline Promethazine & 1.00 & 5.10 \\
\hline Trifluoperazine & 2.20 & 7.00 \\
\hline Pyrido[3,2-g] quinoline derivatives & & 9.2 \\
\hline $4 \mathrm{a}$ & 8.10 & 11.5 \\
\hline $4 \mathrm{~b}$ & 10.90 & 14.8 \\
\hline $4 \mathrm{c}$ & 14.40 & 15.5 \\
\hline 4d & 14.40 & -3.00 \\
\hline Pregnanes & & -0.80 \\
\hline $\mathrm{P}-\mathrm{S} 1 \mathrm{cHe}$ & -0.58 & -3.00 \\
\hline P-S2cHe & -2.66 & -4.10 \\
\hline P-S3cHe & -1.60 & -0.83 \\
\hline P-S1Be & -2.50 & -1.15 \\
\hline P-S2Be & -0.58 & 2.90 \\
\hline P-S3Be & 1.34 & 1.50 \\
\hline Aza-oxafluorenes & -1.50 & \\
\hline Az1 & 0.00 & \\
\hline Az2 & 1.00 & \\
\hline Az3 & & \\
\hline
\end{tabular}

2. Complex formation of antiplasmid compounds with the isolated plasmid DNA from clinical strains

The complex formation of tricyclic compounds such as promethazine and 9-aminoacridine was studied on plasmid DNA isolated from clinical strains. All strains contained plasmids according to Figure 6. Lane 2-11. The extracted plasmid DNA was treated with antiplasmid compounds and the plasmid profiles were detected by agarose gelelectrophoresis. The plasmid profiles of the majority of the strains have been changed after the treatment and shown to differ from the control ones. The strongly intercalating 9-aminoacridine (Figure 6. Lane $14,17,20,23$ ) was more effective concerning its complex formation properties than promethazine (Figure 6. Lane 13, 16, 19, 22). 


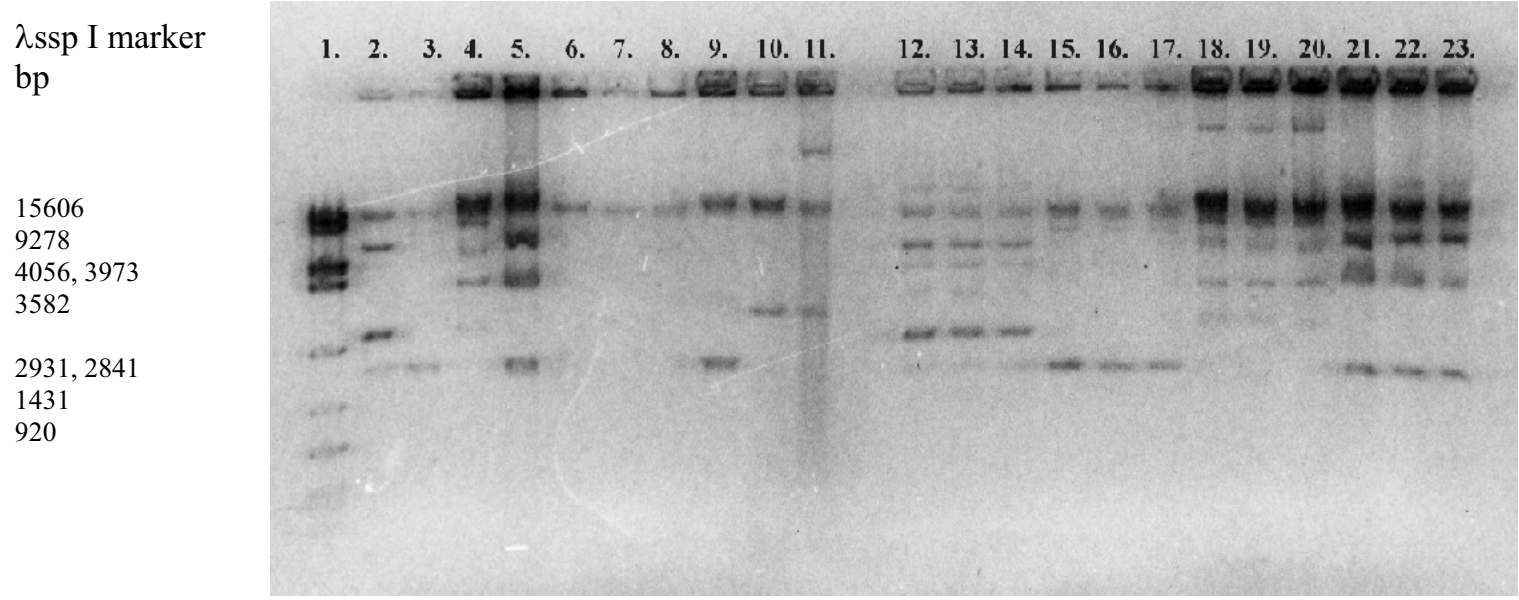

Figure 6. Plasmid profiles of clinical strains untreated (Lane 2-11) and treated with promethazine and 9-aminoacridine.

Treatment: $5 \mu \mathrm{L}$ of promethazine (stock solution $1 \mathrm{mg} / \mathrm{mL}$ ) or $5 \mu \mathrm{L}$ of 9 -aminoacridine (stock solution 0.5 $\mathrm{mg} / \mathrm{mL}$ ) was added to the samples. The samples were incubated for 10 minutes at $37^{\circ} \mathrm{C}$ and then applied in the gel Samples: Lane 1. $\lambda$ sspI marker; Lane 2. E. coli 30906; Lane 3. E. coli 42883; Lane 4. E. coli 34613; Lane 5. E. coli 34561; Lane 6. E. coli 34439; Lane 7. E. coli 42559; Lane 8. E. coli 34253; Lane 9. E. coli 42891; Lane 10. Citrobacter freundii 47051; Lane 11. Enterobacter cloacae 44937; Lane 12. E. coli 30906 control; Lane 13. E. coli 30906 +promethazine; Lane 14. E. coli $30906+9$-aminoacridine; Lane 15. E. coli 42883 control; Lane 16 E. coli 42883 +promethazine; Lane 17. E. coli $42883+9$-aminoacridine; Lane 18. E. coli 34613 control; Lane 19. E. coli $34613+$ promethazine; Lane 20. E. coli $34613+9$-aminoacridine; Lane 21. $E$. coli 34561 control; Lane 22. E. coli $34561+$ promethazine; Lane 23. E. coli $34561+9$-aminoacridine.

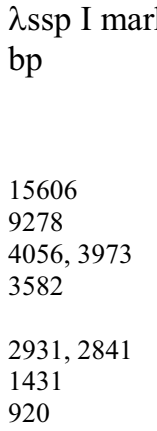

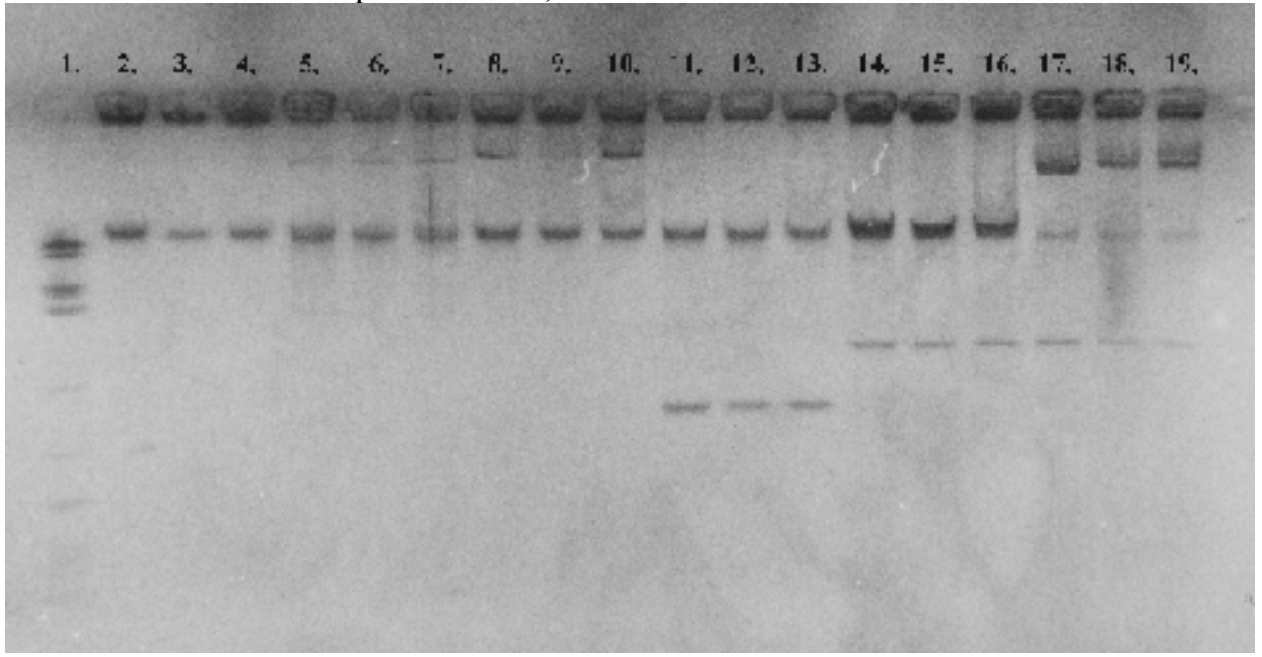

Figure 7. Agarose gelelectrophoresis of the promethazine and 9-aminoacridine treated plasmid DNA from clinical isolates.

Treatment: $5 \mu \mathrm{L}$ of promethazine (stock solution $1 \mathrm{mg} / \mathrm{mL}$ ) or $5 \mu \mathrm{L}$ of 9-aminoacridine (stock solution 0.5 $\mathrm{mg} / \mathrm{mL}$ ) was added to the samples. The samples were incubated for 10 minutes at $37^{\circ} \mathrm{C}$ and then applied in the gel. Samples: Lane 1. $\lambda$ sspI marker, Lane 2. E. coli 34439 control, Lane 3. E. coli $34439+$ promethazine, Lane 4. E. coli $34439+9$-aminoacridine, Lane 5. E. coli 42559 control, Lane 6. E. coli $42559+$ promethazine, Lane 7. E. coli $42559+9$-aminoacridine, Lane 8. E. coli 34253 control, Lane 9. E. coli 34253 + promethazine, Lane 10. E. coli $34253+9$-aminoacridine, Lane 11. E. coli 42891 control, Lane 12. E. coli 42891+promethazine, Lane 13. E. coli 42891+9-aminoacridine, Lane 14. Citrobacter freundii 47051 control, Lane 15. Citrobacter freundii 47051+promethazine, Lane 16. Citrobacter freundii 47051+9-aminoacridine, Lane 17. Enterobacter cloacae 44937 control, Lane 18. Enterobacter cloacae $44937+$ promethazine, Lane 19. Enterobacter cloacae 44937 + 9-aminoacridine 
of $E$. coli.

\section{Identification of $\mathrm{Te}^{\mathrm{r}}$ plasmid by isolation and retransfer from clinical isolate}

The highest frequency of plasmid elimination has been observed in the case of E. coli 42883, for that reason I decided to verify that the doxycycline resistance of this strains is related to the " $\mathrm{Tc}^{\mathrm{r} \text { " }}$ plasmid. The two plasmid bands of E. coli 42883 were detected by agarose gelelectrophoresis, then the bands were isolated from the $0.9 \%$ gel and retransformed into E. coli DH5 $\alpha$ cells separately. As control plasmid pBR322 was used and retrasformed into E. coli DH5 $\alpha$ cells. After retransfer the cells were plated onto doxycycline containing $(30 \mu \mathrm{g} / \mathrm{mL}) \mathrm{LB}$ agar plates and the plates were incubated at $37^{\circ} \mathrm{C}$ for 72 hours. Both plasmid retransfer were successful and the colonies were growing after transformation, the pBR322 control as well. With this experiment I clarified that the doxycycline resistance of E. coli 42883 was encoded by $\operatorname{Tc}^{\mathrm{r}}$ plasmid.

\section{The effect of proton pump inhibitor 1-(2-benzoxazolyl)-3,3,3-trifluoro-2-propanone [TF18] on the action of resistance modifiers in model experiments}

1. Interaction between proton pump inhibitor and antiplasmid compounds from the aspect of antibacterial effect

The combinations employed in these experiments exerted additive antibacterial effect. Synergism was not observed in combination of antiplasmid compounds promethazine, trifluoperazine, 9-aminoacridine and proton pump inhibitor TF18 on E. coli F'lac, the combinations listed above showed additive effect. In case of the doxycycline resistant clinical strain E. coli 42883 the results of interaction of promethazine and TF18 was addition. TF18 acted synergistically with trifluoperazine on the clinical E. coli strain. (Table 5)

Figure 8. Plasmid elimination experiments. A. F'lac plasmid elimination B. Replica plating

A.

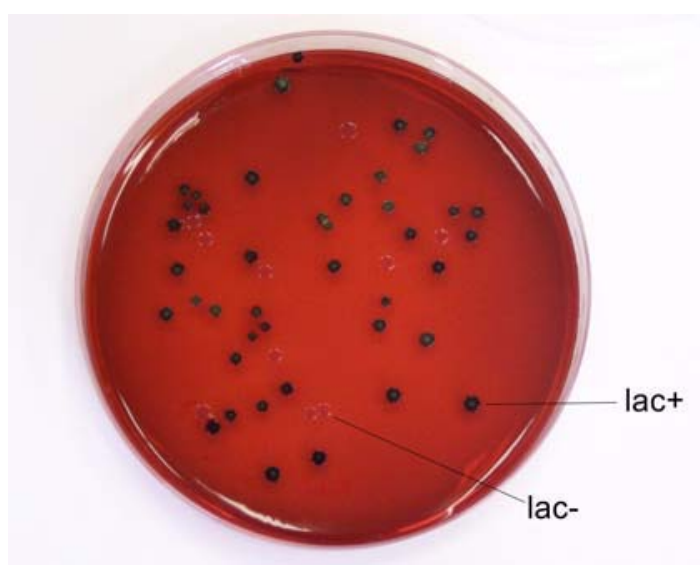

B.

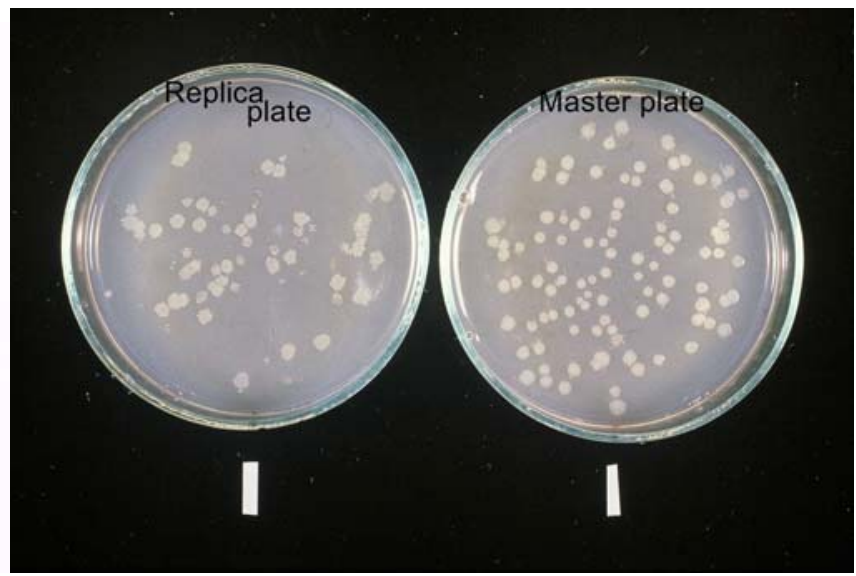


Table 5. Interaction between proton pump inhibitor and antiplasmid compounds on laboratory model E. coli F'lac K12 LE140 and E. coli 42883 clinical bacterial strain

\begin{tabular}{|c|c|c|c|}
\hline \multicolumn{2}{|c|}{$\begin{array}{l}\text { Checkerboard studies on model laboratory } \\
\text { E. coli F'lac K12 LE140 }\end{array}$} & \multicolumn{2}{|c|}{ Checkerboard studies on clinical E. coli 42883} \\
\hline $\begin{array}{l}\text { The effect of the combination } \\
\text { of promethazine and TF18 }\end{array}$ & $\begin{array}{l}\text { Type of } \\
\text { interaction }\end{array}$ & $\begin{array}{l}\text { The effect of the combination of } \\
\text { promethazine and TF } 18\end{array}$ & $\begin{array}{l}\text { Type of } \\
\text { interaction }\end{array}$ \\
\hline $\mathrm{FIC}_{\mathrm{TF} 18}=3.9 / 7.8=0.5$ & \multirow{3}{*}{$\begin{array}{l}\text { ADDITIVE } \\
\text { EFFECT }\end{array}$} & $\mathrm{FIC}_{\mathrm{TF} 18}=15.6 / 31.25=0.5$ & \multirow{3}{*}{$\begin{array}{l}\text { ADDITIVE } \\
\text { EFFECT }\end{array}$} \\
\hline $\mathrm{FIC}_{\text {Promethazine }}=31.5 / 125=0.25$ & & FIC $_{\text {Promethazine }}=31.25 / 125=0.25$ & \\
\hline $\mathrm{FIX}=\mathrm{FIC}_{\mathrm{TF} 18}+\mathrm{FIC}_{\text {Promethazine }}=0.75$ & & $\mathrm{FIX}=\mathrm{FIC}_{\mathrm{TF} 18}+\mathrm{FIC}_{\text {Promethazine }}=0.75$ & \\
\hline $\begin{array}{l}\text { The effect of the combination } \\
\text { of trifluoperazine and TF } 18\end{array}$ & & $\begin{array}{l}\text { The effect of the combination of } \\
\text { trifluoperazine and TF } 18\end{array}$ & \\
\hline $\mathrm{FIC}_{\mathrm{TF} 18}=3.9 / 7.8=0.5$ & \multirow{3}{*}{$\begin{array}{l}\text { ADDITIVE } \\
\text { EFFECT }\end{array}$} & $\mathrm{FIC}_{\mathrm{TF} 18}=0.98 / 31.25=0.03$ & \multirow{3}{*}{$\begin{array}{l}\text { SYNERGISTIC } \\
\text { EFFECT }\end{array}$} \\
\hline $\mathrm{FIC}_{\mathrm{TFP}}=31.25 / 62.5=0.5$ & & $\mathrm{FIC}_{\mathrm{TFP}}=15.6 / 125=0.12$ & \\
\hline $\mathrm{FIX}=\mathrm{FIC}_{\mathrm{TF} 18}+\mathrm{FIC}_{\mathrm{TFP}}=1$ & & $\mathrm{FIX}=\mathrm{FIC}_{\mathrm{TF} 18}+\mathrm{FIC}_{\mathrm{TFP}}=0.15$ & \\
\hline $\begin{array}{l}\text { The effect of the combination } \\
\text { of 9-aminoacridine and TF } 18\end{array}$ & \multirow{4}{*}{$\begin{array}{l}\text { ADDITIVE } \\
\text { EFFECT }\end{array}$} & \multirow{4}{*}{\multicolumn{2}{|c|}{$\begin{array}{l}\text { In order to evaluate the outcome of the drug } \\
\text { combination, fractional inhibitory concentration (FIX) } \\
\text { indices were calculated as } \text { FIC }_{\mathrm{A}}+\mathrm{FIC}_{\mathrm{B}} \text {, where FIC } \mathrm{F}_{\mathrm{A}} \text {, } \\
\left(\mathrm{MIC}_{\mathrm{A}} \text { in combination/MIC } \mathrm{MI}_{\mathrm{A}} \text { alone) and } \mathrm{FIC}_{\mathrm{B}}\left(\mathrm{MIC}_{\mathrm{B}} \text { in }\right.\right. \\
\text { combination/MIC } \mathrm{C}_{\mathrm{B}} \text { alone) represent the minimum } \\
\text { concentrations of drug A and B that inhibited growth } \\
\text { respectively. Individual checkerboards tests were } \\
\text { repeated twice, the mean FIC index was calculated and } \\
\text { classified as either synergistic }(<0.5) \text {, additive }(0.5-1.0) \text {, } \\
\text { indifferent }(1-4.0) \text { or antagonistic }(>4.0) \text {. }\end{array}$}} \\
\hline $\mathrm{FIC}_{\mathrm{TF} 18}=1.9 / 7.8=0.25$ & & & \\
\hline $\mathrm{FIC}_{9 \mathrm{AA}}=3.9 / 7.8=0.5$ & & & \\
\hline $\mathrm{FIX}=\mathrm{FIC}_{\mathrm{TF} 18}+\mathrm{FIC}_{9 \mathrm{AA}}=0.75$ & & & \\
\hline
\end{tabular}

The importance of antibacterial effect of proton pump inhibitor and its interaction with antiplasmid compounds led to the investigation of plasmid curing by antiplasmid compounds in the presence of proton pump inhibitor.

\section{Interaction between proton pump inhibitor and antiplasmid compounds from the aspect of antiplasmid effect}

The interaction between antiplasmid compounds and inhibitor of bacterial proton pumps has been studied using F'lac plasmid elimination. Agents such as promethazine, trifluoperazine, 
9-aminoacridine were applied alone as control after determination of their highest antiplasmid effect at sub-inhibitory concentration.

The promethazine, trifluoperazine and 9-aminoacridine were combined with 1-(2benzoxazolyl)-3,3,3-trifluoro-2-propanone [TF18] which acts as a proton pump inhibitor. These combinations have been studied for their ability to eliminate bacterial plasmids (Table 6). The F'lac plasmid of Escherichia coli K12 LE140 has served as a convenient model for studying the plasmid-curing effect. The plasmid curing effect of promethazine, trifluoperazine and 9-aminoacridine in the presence of a trifluoroketone, an inhibitor of the proton pump received special consideration. It is important to note that TF18 alone had no antiplasmid effect. PMZ and TFP as well as 9AA have prominent plasmid curing activity against $E$. coli K12 LE 140 (Table 2) and these effects can be substantially enhanced by the presence of the proton pump inhibitor trifluoroketone 18 (TF 18) at concentrations that range from 0.05 to 0.5 $\mu \mathrm{g} / \mathrm{mL}$ (Table 6) (IV).

3. The influence of combination of resistance modifiers such as proton pump inhibitor and $\mathrm{Ca}^{2+}$ channel blocker on the elimination of doxycycline resistance on $E$. coli $\mathbf{4 2 8 8 3}$ doxycycline resistant clinical strain

The combination of proton pump inhibitor and antiplasmid compounds was effective on the model strain carrying F'lac plasmid and consequently the same combination was tested on $E$. coli 42883 clinical isolate whose resistance is related to $\mathrm{Tc}^{\mathrm{r}}$ plasmid.

The plasmid curing effect of $90 \mu \mathrm{g} / \mathrm{mL}$ PMZ was increased from $12.3 \%$ to $27.6 \%$ in presence of $2 \mu \mathrm{g} / \mathrm{mL}$ TF18. The antiplasmid action of TFP was not modified by TF18, on the other hand the co-administration of verapamil $\left(\mathrm{Ca}^{2+}\right.$-antagonist) and trifluoperazine (intercalating plasmid curing compound) resulted in remarkable increase of plasmid elimination: TFP alone exerted $6.76 \%$ plasmid curing activity at $50 \mu \mathrm{g} / \mathrm{mL}$, in combination with $5 \mu \mathrm{g} / \mathrm{mL}$ verapamil the ratio of plasmidfree colonies was found to be $25.6 \%$ (Table 7 ).

Table 6.A-C. Ratio of plasmid elimination on E. coli K12 LE 140 in the presence of promethazine, trifluoperazine (TFP), 9-aminoacridine (9AA) and trifluoroketone TF 18

6.A.

\begin{tabular}{|l|l|l|l|l|l|l|l|}
\hline Samples & $\begin{array}{l}\text { Concentration } \\
(\mu \mathrm{g} / \mathrm{mL})\end{array}$ & \multicolumn{3}{|l|}{ Plasmid curing \% } & Mean & SD \\
\hline Untreated control & - & 0 & 0 & 0 & 0 & 0 & 0 \\
\hline Promethazine+TF18 & $\mathbf{6 0 + 0}$ & 50 & 35.9 & 24 & 44.12 & 38.5 & 9.8 \\
\hline & $\mathbf{6 0}+\mathbf{0 . 0 5}$ & 93.75 & 100 & 25 & 84.5 & 75.8 & 29.9 \\
\cline { 2 - 10 } & $\mathbf{6 0}+\mathbf{0 . 1}$ & 83.93 & 50 & 52.11 & 68.8 & 63.7 & 13.8 \\
\cline { 2 - 10 } & $\mathbf{6 0}+\mathbf{0 . 5}$ & 99.58 & 0 & 96.95 & - & 65.4 & 46.3 \\
\cline { 2 - 9 } & $\mathbf{6 0}+\mathbf{1}$ & & 0 & - & - & 0 & 0 \\
\cline { 2 - 9 } & $\mathbf{6 0}+\mathbf{2}$ & & - & - & - & - & \\
\hline
\end{tabular}


6.B.

\begin{tabular}{|l|l|l|l|l|l|l|r|}
\hline Samples & $\begin{array}{l}\text { Concentration } \\
(\mu \mathrm{g} / \mathrm{mL})\end{array}$ & \multicolumn{4}{l|}{ Plasmid curing \% } & Mean & SD \\
\hline Untreated control & - & 0 & 0 & 0 & 0 & 0 & 0 \\
\hline TFP+TF18 & $\mathbf{2 0 + 0}$ & 8.89 & 2.28 & 5.26 & 0 & 4.1 & 3.3 \\
\hline \multirow{5}{*}{} & $\mathbf{2 0}+\mathbf{0 . 0 5}$ & 14.23 & 39.07 & 1.07 & 21.32 & 18.9 & 13.7 \\
\cline { 2 - 9 } & $\mathbf{2 0}+\mathbf{0 . 1}$ & 17.1 & 2.16 & 4.42 & 40.59 & 16.1 & 15.3 \\
\cline { 2 - 9 } & $\mathbf{2 0}+\mathbf{0 . 5}$ & 0 & 2.02 & 39.34 & 6.89 & 12.1 & 15.9 \\
\cline { 2 - 9 } & $\mathbf{2 0}+\mathbf{1}$ & 0 & 0 & 2.4 & 0.09 & 0.6 & 1.0 \\
\cline { 2 - 9 } & $\mathbf{2 0}+\mathbf{2}$ & - & - & - & - & - & - \\
\hline
\end{tabular}

6.C.

\begin{tabular}{|l|l|l|l|l|l|l|l|}
\hline Samples & \multicolumn{4}{|l|}{$\begin{array}{l}\text { Concentration } \\
(\mu \mathrm{g} / \mathrm{mL})\end{array}$} & \multicolumn{4}{|l|}{ Plasmid curing \% } & Mean & SD \\
\hline Untreated control & - & 0 & 0.04 & 0.04 & 0.04 & 0.03 & 0.02 \\
\hline $\mathbf{9 A A + T F 1 8}$ & $\mathbf{5 + 0}$ & 40.9 & 52.83 & 67.92 & 60.42 & 55.5 & 9.98 \\
\hline \multirow{5}{*}{} & $\mathbf{5 + 0 . 0 5}$ & 57.97 & 56.2 & 68.42 & 35.1 & 54.4 & 12.1 \\
\cline { 2 - 9 } & $\mathbf{5 + 0 . 1}$ & 31.78 & 87.9 & 94.12 & 42.72 & 64.1 & 27.2 \\
\cline { 2 - 9 } & $\mathbf{5 + 0 . 5}$ & 74.78 & 86.27 & 66.7 & 70.52 & 75.3 & 7.3 \\
\cline { 2 - 9 } & $\mathbf{5 + 1}$ & 84 & 87.5 & - & 84.1 & 85.2 & 1.6 \\
\cline { 2 - 8 } & $\mathbf{5 + 2}$ & - & - & - & - & - & \\
\hline
\end{tabular}

Table 7. The frequency of plasmid elimination on doxycycline resistant E. coli 42883 in the presence of promethazine $+\mathbf{T F 1 8}$, trifluoperazine $+\mathbf{T F} 18$ and trifluoperazine + verapamil

\begin{tabular}{|l|l|l|l|l|l|l|l|l|l||}
\hline \begin{tabular}{|l} 
E.coli 42883 \\
Micro method
\end{tabular} & \multicolumn{2}{l|}{$\begin{array}{l}\text { Number of colony formers } \\
\text { cfu/mL }\end{array}$} & \multicolumn{2}{l|}{ Plasmid elimination\% } & Mean & SD \\
\hline concentration $\mu \mathrm{g} / \mathrm{mL}$ & Exp1 & Exp2 & Exp3 & Exp1 & Exp2 & Exp3 & & \\
\hline Control & 0 & $2 \times 10^{9}$ & $1.3 \times 10^{9}$ & $1.1 \times 10^{9}$ & 0 & 0 & 0 & 0 & 0 \\
\hline PMZ & 10 & $2.5 \times 10^{9}$ & $9.5 \times 10^{8}$ & $2.1 \times 10^{9}$ & 0 & 4.2 & 0 & 1.4 & 2.42 \\
\hline & 30 & $1.6 \times 10^{9}$ & $1.2 \times 10^{9}$ & $5 \times 10^{8}$ & 4.5 & 19.8 & 6 & 10.1 & 8.43 \\
\hline & 50 & $6.5 \times 10^{8}$ & $6.3 \times 10^{8}$ & $7.5 \times 10^{8}$ & 3.1 & 15.9 & 2.7 & 7.23 & 7.51 \\
\hline & 70 & $7.9 \times 10^{8}$ & $3.4 \times 10^{9}$ & $3.6 \times 10^{8}$ & 8.7 & 12 & 2.8 & 7.83 & 4.66 \\
\hline & 90 & $4.4 \times 10^{8}$ & $4.3 \times 10^{8}$ & $4.5 \times 10^{8}$ & 9.1 & 27.9 & 0 & 12.33 & 14.23 \\
\hline & 110 & $2.3 \times 10^{7}$ & $M I C$ & $1.2 \times 10^{9}$ & 0 & & 0 & 0 & 0 \\
\hline & 120 & $M I C$ & & $M I C$ & & & & & \\
\hline PMZ+ \\
TF18 & $10+2$ & $2.2 \times 10^{9}$ & $1.4 \times 10^{9}$ & $9 \times 10^{8}$ & 0 & 10.6 & 2.2 & 4.27 & 5.59 \\
\hline & $30+2$ & $7.6 \times 10^{8}$ & $5.6 \times 10^{8}$ & $4.8 \times 10^{8}$ & 6.6 & 5.4 & 2.1 & 4.7 & 2.33 \\
\hline & $50+2$ & $1 \times 10^{9}$ & $1.1 \times 10^{9}$ & $4.6 \times 10^{8}$ & 13.6 & 0 & 2.2 & 5.27 & 7.30 \\
\hline & $70+2$ & $4.8 \times 10^{8}$ & $4.7 \times 10^{8}$ & $4 \times 10^{8}$ & 4.2 & 8.5 & 15 & 9.23 & 5.44 \\
\hline & $90+2$ & $5.3 \times 10^{8}$ & $6 \times 10^{7}$ & $1.1 \times 10^{8}$ & 7.5 & 64.7 & 10.7 & 27.63 & 32.14 \\
\hline & $110+2$ & $M I C$ & $M I C$ & $M I C$ & & & & & \\
\hline Control & 0 & $1.3 \times 10^{9}$ & $2 \times 10^{9}$ & $1.3 \times 10^{9}$ & 0 & 0 & 0 & 0 & 0 \\
\hline TFP & 10 & $4.7 \times 10^{8}$ & $1.1 \times 10^{9}$ & $2.3 \times 10^{8}$ & 4.3 & 0 & 8.7 & 4.33 & 4.35 \\
\hline & 30 & $3 \times 10^{7}$ & $3 \times 10^{7}$ & $3.8 \times 10^{8}$ & 0 & 0 & 0 & 0 & 0 \\
\hline & 50 & $1.3 \times 10^{8}$ & $1.8 \times 10^{8}$ & $4.2 \times 10^{7}$ & 0 & 0 & 2.4 & 0.8 & 1.39 \\
\hline TFP+TF18 & $10+2$ & $1.8 \times 10^{8}$ & $4.8 \times 10^{8}$ & $4.6 \times 10^{8}$ & 0 & 8.3 & 4.3 & 4.2 & 4.15 \\
\hline & $30+2$ & $6.3 \times 10^{8}$ & $2.3 \times 10^{8}$ & $3 \times 10^{7}$ & 11.1 & 0 & 0 & 3.7 & 6.41 \\
\hline & $50+2$ & $7 \times 10^{7}$ & $M I C$ & $M I C$ & 0 & 0 & 0 & 0 & 0 \\
\hline & $60+2$ & $M I C$ & & & & & & \\
\hline
\end{tabular}


Table 7. continued

\begin{tabular}{||l|l|l|l|l|l|l|l|l|l||}
\hline \hline $\begin{array}{l}\text { E.coli 42883 } \\
\text { Micro method }\end{array}$ & \multicolumn{2}{l|}{$\begin{array}{l}\text { Number of colony formers } \\
\text { cfu/mL }\end{array}$} & \multicolumn{2}{l|}{ Plasmid elimination\% } & Mean & SD \\
\hline concentration $\mu \mathrm{g} / \mathrm{mL}$ & Exp1 & Exp2 & Exp3 & Exp1 & Exp2 & Exp3 & & \\
\hline Control & 0 & $9.7 \times 10^{8}$ & $1.9 \times 10^{9}$ & $1.1 \times 10^{9}$ & 0 & 0 & 0 & 0 & 0 \\
\hline TFP & 10 & $5.2 \times 10^{8}$ & $1.2 \times 10^{9}$ & $7.1 \times 10^{8}$ & 7.7 & 0.8 & 4.2 & 4.23 & 3.45 \\
\hline & 30 & $1.6 \times 10^{8}$ & $3.9 \times 10^{8}$ & $1.3 \times 10^{8}$ & 0 & 12.8 & 7.7 & 6.83 & 6.44 \\
\hline & 50 & $8 \times 10^{7}$ & $2.8 \times 10^{8}$ & $6.0 \times 10^{7}$ & 0 & 3.6 & 16.7 & 6.77 & 8.79 \\
\hline & 60 & $4.2 \times 10^{6}$ & $1.9 \times 10^{8}$ & $M I C$ & 0 & 0 & & 0 & 0 \\
\hline & 70 & $M I C$ & $M I C$ & & & & & & \\
\hline $\begin{array}{l}\text { TFP+ } \\
\text { Verapamil }\end{array}$ & $10+5$ & $5.5 \times 10^{8}$ & $2.8 \times 10^{9}$ & $3.4 \times 10^{8}$ & 9.1 & 0 & 5.9 & 5 & 4.62 \\
\hline & $30+5$ & $1.4 \times 10^{8}$ & $1.4 \times 10^{9}$ & $4.0 \times 10^{8}$ & 7.1 & 0 & 5 & 4.03 & 3.65 \\
\hline & $50+5$ & $1.4 \times 10^{8}$ & $2.6 \times 10^{8}$ & $9.6 \times 10^{6}$ & 21.4 & 26.9 & 28.5 & 25.6 & 3.72 \\
\hline & $60+5$ & $8 \times 10^{7}$ & $1.7 \times 10^{6}$ & $M I C$ & 0 & 1.7 & & 0.85 & 1.20 \\
\hline & $70+5$ & $M I C$ & $M I C$ & & & & & & \\
\hline
\end{tabular}

4. Specific effect of proton pump inhibitor on a model of Helicobacter pylori: antibacterial and antimotility studies

The newly developed proton pump inhibitor, 1-(2-benzoxazolyl)-3,3,3-trifluoro-2propanone [TF18] was studied for antibacterial action on clarithromycin susceptible and resistant $H$. pylori strains alone and in combination with clarithromycin in checkerboard experiments. The sensitivity of proton motive force to TF18 was studied by inhibition of motility on CSHP and CRHP strains. The MIC values $(\mu \mathrm{g} / \mathrm{mL})$ of clarithromycin against CSHP and CRHP were 0.0156 and 31.25, respectively. The MICs of TF18 were 31.25 for CSHP and 0.78 for CRHP. Interaction of clarithromycin with TF18 was additive in both strains (Table 8) concerning the antibacterial effects of these compounds (VI,VIII).

Table 8. MIC values of clarithromycin and TF 18 on clarithromycin susceptible Helicobacter pylori ATCC 700392 (CSHP) and clarithromycin resistant Helicobacter pylori 9447 (CRHP) strains determined by checkerboard microdilution method

MIC values $\mu \mathrm{g} / \mathrm{mL}$

\begin{tabular}{lc|c}
\hline Samples & $\begin{array}{l}\text { Helicobacter pylori 26695 } \\
\text { (clarithromycin susceptible) }\end{array}$ & $\begin{array}{l}\text { Helicobacter pylori 9447 } \\
\text { (clarithromycin resistant) }\end{array}$ \\
\hline Clarithromycin $(\mu \mathrm{g} / \mathrm{mL})$ & 0.0156 & 31.25 \\
$\mathrm{TF} 18(\mu \mathrm{g} / \mathrm{mL})$ & 31.25 & 0.78 \\
Interaction between & ADDITIVE & ADDITIVE \\
clarithromycin and TF18 & & \\
\hline
\end{tabular}


Both CSHP and CRHP cells were moderately motile when the swimming and tumbling were measured on the phase contrast microscopy. The inhibition of motility of CSHP was found in presence of TF 18 at sub-inhibitory concentration (Table 9). At 10\% MIC $(3.12 \mu \mathrm{g} / \mathrm{mL})$, a slight inhibition was found in the movement. At $50 \% \mathrm{MIC}(15.6 \mu \mathrm{g} / \mathrm{mL})$, the swimming bacterial cells could not be detected under the microscope. The tumbling was not influenced, while the number of non-motile cells was increased. At 90\% MIC, the number of non-motile cells was further increased and the tumbling was decreased. Similar results were also obtained at $200 \%$ of MIC. The increase in the concentration modified the tumbling and caused total movement inhibition.

Table 9. Antimotility effect of TF18 on clarithromycin susceptible Helicobacter pylori ATCC 700392 (CSHP) and clarithromycin resistant Helicobacter pylori 9447 (CRHP) strains

\begin{tabular}{lccc|ccc}
\hline \multicolumn{5}{c|}{ Amount of CSHP in the evaluated cells* } & \multicolumn{3}{l}{ Amount of CRHP in the evaluated cells* } \\
\hline Conc. of TF18 & Swimming & Tumbling & Non-motile & Swimming & Tumbling & Non-motile \\
\hline Control & 21.7 & 52.8 & 25.5 & 68.3 & 12.7 & 19.0 \\
$10 \%$ MIC & 16.7 & 47.4 & 35.9 & 40.0 & 12.0 & 48.0 \\
$50 \%$ MIC & 0 & 53.2 & 46.8 & 0 & 32.6 & 67.4 \\
$90 \%$ MIC & 0 & 31.0 & 69.0 & 0 & 19.8 & 70.2 \\
$200 \%$ MIC & 0 & 23.0 & 77.0 & 0 & 0 & 100 \\
\hline
\end{tabular}

*approximately 300-400 cells were counted

For the CRHP strain, the untreated control sample contained more swimming cells than CSHP, 68.3 and $21.7 \%$, respectively. The ratio (12.7\%) of tumbling cells was less than in case of CSHP $(52.8 \%)$. At $10 \%$ MIC $(0.078 \mu \mathrm{g} / \mathrm{mL})$, the number of swimming cells decreased and non-motile cells were increased, whereas the tumbling was not influenced. At $50 \%$ MIC $(0.39 \mu \mathrm{g} / \mathrm{mL})$, the swimming was completely blocked, however, the tumbling increased from 12.0 to $32.6 \%$. At $90 \%$ MIC $(0.70 \mu \mathrm{g} / \mathrm{mL}), 70 \%$ of the cells were non-motile, furthermore at $200 \%$ MIC $(1.56 \mu \mathrm{g} / \mathrm{mL})$ only non-motile cells were found; however swimming and tumbling cells could not be detected.

Swimming was more sensitive to the inhibition than tumbling in both CSHP and CRHP strains. The antimotility effect of TF18 was more pronounced at sub-inhibitory concentration in CRHP than in CSHP. The different phases of motility had shown various sensibilities to TF18. One of the most interesting findings is the difference between inhibition 
of flagellar movements in case of clarithromycin resistant and sensitive Helicobacter pylori, where the antibiotic resistant $H$. pylori was more sensitive to motility inhibition than the antibiotic susceptible strain.

\section{Efflux model in cancer cells}

Reversal of multidrug resistance of mouse lymphoma cells with synthetic and plant derived compounds

Based on the experiments on drug-efflux model on bacterial systems the resistance reversal effect of different compounds such as synthetic and plant derived compounds was investigated on drug accumulation in mouse lymphoma cells transfected with the human MDR1 gene (131).

\section{A. Synthetic compounds designed to block the P-gp mediated efflux}

A.1. Benzo[b]-1,8-naphthyridine derivatives [1-21] were tested for MDR reversing activity compared to the reference drug verapamil. Of the 21 compounds studied, 14 showed promising MDR reversing activity with higher potency than verapamil. Ratios of fluorescence activity were in the range of 0.6 to 108.98 at the lower concentration $(4 \mu \mathrm{g} / \mathrm{mL})$ and of 3.6 to 166.08 at the higher concentration $(40 \mu \mathrm{g} / \mathrm{mL})$. Some of the substitutions in the polycyclic nucleus of benzonaphthyridine derivatives also resulted in effective MDR inhibitors. The size of nucleus of tetracyclics has a great influence on MDR reversing effect (compounds 16-21) (I).

\section{A.2. Pyrido[3,2-g]quinoline derivatives}

The monosubstituted pyrido[3,2-g] quinolines (4a-d) had remarkable MDR reversing effect on mouse lymphoma cells at lower concentration $(4 \mu \mathrm{g} / \mathrm{mL})$ and their P-glycoprotein modulating activity was 7-8 times higher than the activity of verapamil applied as reference P-gp substrate. Compound 4d was toxic at the highest concentration (Table 10) (IX).

Table 10. Effects of monosubstituted pyrido[3,2-g] quinolines (4a-d) on P-gp mediated drug efflux.

\begin{tabular}{||l|c|c||}
\hline \multicolumn{1}{|c|}{ Compounds } & $\begin{array}{c}\text { Concentration } \\
\boldsymbol{\mu g} / \mathbf{m L}\end{array}$ & $\begin{array}{c}\text { Fluorescence Activity } \\
\text { Ratio }\end{array}$ \\
\hline Verapamil & 10 & 6.06 \\
\hline 4a & 4 & 40.18 \\
\hline & 40 & 43.55 \\
\hline 4b & 4 & 43.10 \\
\hline & 40 & 49.83 \\
\hline 4c & 4 & 38.96 \\
\hline & 40 & 47.55 \\
\hline 4d & 4 & 53.09 \\
\hline DMSO & 40 & 43.12 \\
\hline \hline
\end{tabular}


A.3. Pregnane derivatives: In the case of substituted pregnane derivatives the following compounds were extremely effective inhibitors of the P-gp 170: PS3-Be, PS2-cHe, PS2-Be. Compounds PS1-Be and PS1-cHe were almost ineffective in low concentration from 1-16 $\mu \mathrm{g} / \mathrm{ml}$. Compound PS3-cHe was toxic at this highest concentration. The main difference between inhibitor and inactive structures is the substitution of $\mathrm{S}$ on the carrier pregnane skeleton. (Table 11) (IX)

Table 11. Effect of pregnane derivatives on P-gp mediated drug efflux.

\begin{tabular}{|l|c|c|}
\hline \multicolumn{1}{|c|}{ Compounds } & Concentration $\boldsymbol{\mu g} / \mathbf{m L}$ & Fluorescence Activity Ratio \\
\hline Verapamil & 10 & 5.02 \\
\hline P-S2cHe & 4 & 4.7 \\
\hline & 8 & 18.61 \\
\hline P-S2Be & 16 & 56.45 \\
\hline & 4 & 6.28 \\
\hline & 8 & 10.66 \\
\hline P-S3Be & 16 & 22.83 \\
\hline & 1 & 3.89 \\
\hline & 2 & 11.27 \\
\hline DMSO control & 4 & 45.37 \\
\hline
\end{tabular}

A.4. Aza-oxafluorenes: Among the diazatetraasterane compounds, Az1 and Az2 with additional lipophilic substitution patterns (benzyl and phenoxycarbonyl groups attached to the nitrogen atoms) proved to be more effective than the less lipophilic methoxycarbonyl substituted compound Az3. So it has to be concluded that their MDR-reversal activity resulted from different effects on P-gp 170 (Table 12) (IX).

Table 12. MDR reversal of some aza-oxafluorenes (Az1-3) on mouse T-lymphoma cell line

\begin{tabular}{|l|c|c||}
\hline \hline Compounds & Concentration $\boldsymbol{\mu g} / \mathbf{m L}$ & Fluorescence Activity Ratio \\
\hline Verapamil & 10 & 7.27 \\
\hline Az1 & 4 & 30.19 \\
\hline & 40 & 24.83 \\
\hline Az2 & 4 & 28.10 \\
\hline & 40 & 30.87 \\
\hline Az3 & 4 & 1.11 \\
\hline & 40 & 18.62 \\
\hline DMSO & 20 & 0.99 \\
\hline
\end{tabular}




\section{B. Compounds of natural origin}

\section{$\underline{\text { B.1. Coumarin derivatives }}$}

The MDR reversing effect of 44 coumarins [C1-44] was compared to that of $( \pm)$-verapamil, using a mouse lymphoma cell line (L-5178 cells). The most effective MDR reversing compound $\mathbf{C 4 3}(\mathrm{FAR}=5.66$ at $40 \mu \mathrm{g} / \mathrm{mL})$ was three times less active than $( \pm)$-verapamil and the compound $\mathbf{C 3 4}(\mathrm{FAR}=17.98$ at $40 \mu \mathrm{g} / \mathrm{mL})$ was equipotent to $( \pm)$-verapamil $(\mathrm{FAR}=18.34$ at $10 \mu \mathrm{g} / \mathrm{mL})(\mathrm{X})$

\section{B.2. Persimmon (Diospyros kaki) peel extracts}

Diospyros kaki (Ebenaceae) has been cultivated in Japan for several centuries. Persimmon is a good source of nutritional antioxidant vitamins, polyphenols and dietary fibers. Furthermore, the concentration of carotenoids and polyphenols is higher in the peel than in the pulp of the fruit. Significant MDR-modulating activity was found in two methanol fractions such as M2 and M3. I have to mention that some other fractions from hexane extract were also able to inhibit MDR efflux (III).

\section{$\underline{\text { B.2. Indian tea leaves, Indian coffee seeds and chicory extracts }}$}

Fifteen methanol extracts [M1-M15] of Indian tea leaves [1-7] and coffee seeds [8-15] were tested on the P-glycoprotein mediated MDR efflux pump of tumour cells using mouse lymphoma L-5178 cell line. The MDR reversing effect of methanol extracts [M1-M15] of coffee by different origin were compared to that of verapamil. The effect of extract M6 (FAR 5.26) was compared to verapamil (FAR 8.41) as a control. The extracts of tea and coffee seeds were practically ineffective (II).

\section{Apoptosis induction as an alternative cell death on mouse lymphoma cells}

The growth of tumour cells can be inhibited by chemotherapeutics or in combination of chemotherapeutics with resistance modifiers. Tumour cells also can be eliminated by induction of apoptosis.

The effects of cycloartanes on apoptosis have been investigated (V). The results show that the death rate in the presence of the compounds is extremely low. In case of multidrug resistant MDR cells the direct cytotoxic effect is more pronounced than on the drug sensitive cells. The results can be compared to the positive control, $12 \mathrm{H}$-benzo( $\alpha)$-phenothiazine.

The parent mouse lymphoma cells are more sensitive in the induction of early apoptosis by cycloartane triterpenes than the human MDR1 transfected subline. According to these data, compounds 5, 8, 9 and 12 can be considered as moderate apoptosis inducers. However complete apoptosis was somewhat higher in MDR cells than in PAR cells in presence of $12 \mathrm{H}-$ 
benzo(a)-phenothiazine as control. The effect of cycloartanes was studied at first on the sensitive parent cell line. Apparently the „early” apoptosis was a little bit higher than the complete apoptosis. The results may be related to the direct membrane effect of cycloartanes, when phosphatidyl serine translocation occurs. The apoptosis induction of cycloartanes can be considered as marginal effect on tumour cells.

\section{DISCUSSION}

$\mathrm{ABC}$ transporters of bacteria and cancer cells have some similarities, therefore the two systems were studied and compared based on the presence of $\mathrm{ABC}$ transporters pump antibiotics out of the cells e.g. tetracyclines in the thesis.

Both plasmid and chromosomally mediated resistance can cause therapeutic failures in the practice of chemotherapy. To overcome the antibiotic resistance question there are several opportunities: inhibitors of antibiotic destroying enzymes can be administered together with the antibiotics such as inhibitors of beta-lactamases in combination of penicillin or cephalosporines. In life threatening infections certain antibiotic combinations are recommended.

Apart from the mentioned examples there are no other opportunities to maintain the effect of traditional antibiotics on resistant microorganisms, therefore the main target was to perform model experiments a) to eliminate the genetic base of resistance, to cure bacterial plasmids; b) to block $\mathrm{ABC}$ and proton transporters of bacteria in a hope that the intracellular drug concentration can be increased to an effective level in bacteria.

Before the antiplasmid studies the antibacterial effect (MIC values) of model compounds were determined considering that antiplasmid effects can be measured only in a concentration range, which allows suboptimal growth. Based on the previous studies it is known that the plasmid replication process is more sensitive to a special group of compounds called antiplasmid compounds than the replication of bacteria itself $(93,94)$. As a model the F'prime plasmid was always used for pre-screening for antiplasmid effects. The antiplasmid action of the compounds depends on the chemical structure of amphyphillic compounds having planar ring system with substitution in the L-molecular region. A symmetric pielectron conjugation at the highest occupied molecular orbitals favours the antiplasmid effect $(91,92)$. When the native plasmid DNA and its promethazine complex was analysed in earlier studies, the superhelical form was missing from the promethazine treated plasmid DNA. The open circular and linear forms of plasmid DNA were increased in promethazine treated 
samples $(89,94,99)$. The compounds, which had F'lac plasmid curing ability, were involved in curing experiments on clinical and laboratory strains of various Gram-negative enteric bacteria in this study. In addition, agents such as promethazine and acridine orange which have antibacterial activities have also been shown to reverse antibiotic resistance of various bacterial species $(86,95,96)$ and in this study 9-aminoacridine exerted the most potent antimicrobial activity due to its planar ring system. Trifluoroperazine had more active antimicrobial effect because of its higher electronegativity compared to promethazine.

In plasmid curing experiments the model (the positive controls) were tricyclic compounds e.g. PMZ, TFP, 9AA having planar structure in their skeleton, which enables them to intercalate into the DNA. The primary effects of tricyclic drugs on membrane can lead to disturbances in membrane bound functions like plasmid DNA replication, furthermore the drug treatment induces the formation of linear plasmids and relaxed topoisomers $(88,89,132)$. Tricyclic drugs are also known to cause ATPase inhibition via membrane damages $(133,134)$. It has been shown that promethazine is effective in the elimination of different plasmids $(87,95,99)$ whereas some other phenothiazine derivatives and benz(c)acridines have mainly antibacterial activity. Some amino-acridines have more active antibacterial effect than imino-acridines, imino-acridines have a more powerful antiplasmid effect than the amino-derivatives $(100,117,119)$

With few exceptions, tetracycline-resistant pathogens owe their resistance to the acquisition of tetracycline resistance genes (136). Currently, 33 different tetracycline resistance genes (tet genes) have been characterized, in addition to 3 oxytetracycline resistance genes (otr genes) found in the tetracycline-producing Streptomyces and Mycobacterium species. Twenty-three of these genes code for efflux pumps and belong to the major facilitator superfamily (61). All of these tet efflux genes code for energy-dependent, membraneassociated proteins, which export tetracycline out of the cell. This reduces the intracellular concentration of tetracycline and protects most of the ribosomes from the action of tetracycline. Twenty-one of the efflux genes are found exclusively in Gram-negative bacteria, whereas tet $(\mathrm{K})$ and tet $(\mathrm{L})$ are found primarily in Gram-positive isolates, although a few Gram-negative isolates with either tet $(\mathrm{K})$ or tet (L) have been described (136). All of these genes confer resistance to tetracycline and doxycycline. However, the tet (B) gene confers resistance to tetracycline, doxycycline, and minocycline but not to glycylcyclines. The tet (B) gene has the widest host range among Gram-negative pathogens. Thirty-eight acquired tetracycline resistant $\mathrm{Tc}^{\mathrm{r}}$ genes are known of which nine are new and include five genes 
coding for energy-dependent efflux proteins, two genes coding for ribosomal protection proteins, and two genes coding for tetracycline inactivating enzymes $(137,138)$.

It was interesting that the clinical isolates were less sensitive for the plasmid elimination than the laboratory F'lac strain compared to former results $(100,106)$. Former results also showed that the simultan elimination of F'lac and pBR322 plasmid could be done with relatively high frequency from $E$. coli $(89,96)$. The Ca-binding protein encoding plasmid responsible for virulence of $Y$. enterocolitica and $Y$. pseudotuberculosis isolates was cured with rather low frequency (87). It turned out that the curing efficiency of phenothiazines depends also on the host cells, since the same plasmid was curable with different frequencies from various $E$. coli strains $(99,102)$.

Furthermore there was a difference between the curing effect of PMZ and TFP in some $E$. coli strains in this study (IV). The results show, that the high electronegativity of the TFP does not favour plasmid curing in some bacteria. The possible explanation for this phenomenon is the composition of cell wall, maybe membrane structure. Molnár et al hypothesize that the binding of tricyclic drugs preferentially displaces the bivalent cations, resulting in uncharged membrane lipids and crystalline-liquid phase transition with increased fluidity in the membrane compartments. On this altered membrane structure the plasmid DNA cannot bind to the replication site and some plasmid specific enzymes, such as DNA-gyrase or DNA-polymerase, can be inhibited (99). I suppose that the compound binds strongly to the cell wall components and its penetration is low (135). There are observations for the opposite situation when TFP is more effective than PMZ (Table 3.B., 3.C.). The third type of results shows that the permeation of the two phenothiazine compounds can be the same, the biological effect was nearly the same on E. coli 42883 (Table 3.E.). Finally, I had clinical isolates, from which I was not able to eliminate the tetracycline resistance with PMZ and TFP (IV). In this last case there were two opportunities for explanation of the results: a) the tetracycline resistance is located on the bacterial chromosome and is not mediated by the plasmid b) the other opportunity is that the plasmid replication machinery in these strains is not sensitive to the phenothiazines. This explanation can be supported by earlier observations when some multicopy plasmids were not able to cure from some bacteria $(87,99)$.

The plasmid curing is a complex process that needs the inhibition of various biochemical processes simultaneously like replication of the plasmid DNA, partition and retransfers to the already cured bacterial cell that can be considered as a recipient, theoretically at least (VII).

After plasmid curing experiments the direct interactions of different groups of compounds with calf thymus DNA and plasmid DNA have also been investigated. The most 
effective compounds, the pyrido[3,2-g] quinoline derivatives possess the same heterocyclic nucleus with variations in the side chain. The weaker binding of $4 \mathrm{a}$ and $4 \mathrm{~b}$ may be rationalised by the bulky alkyl groups surrounding the side chain nitrogen that could cause some steric interference to binding. On the other hand $4 \mathrm{c}$ and $4 \mathrm{~d}$ contain five and six membered pyrrolidine and piperidine ring structures in the side chain, which are less bulky and produce less interference (IX).

Chemically the pregnane derivatives investigated consist of three families with varying side chains within each family. An analysis of the $\Delta \mathrm{T}_{\mathrm{m}}$ values shows that there is no obvious correlation, either between the three families, between the $\Delta \mathrm{T}_{\mathrm{m}}$ values obtained and the structural variations within the pregnanes investigated. It must be assumed that the alteration of the oxidation state of the sulphur atom with the same side chains or the variations of the latter within the same thioether, sulphoxide or sulphone family can produce both electronic and spatial differences. These competing variations would be expected to result in a complex structure activity pattern in these compounds. The polarity of the pregnanes increases in order $\mathrm{P}-\mathrm{S} 1<\mathrm{P}-$ $\mathrm{S} 2<\mathrm{P}-\mathrm{S} 3$ and whereas this shows very little effect on the interaction with DNA, which is anyway weak. A further contributing effect is the size of the R group attached to the sulphur (compare PS1Me, P-S2Me and P-S3Me) (IX).

It is already known from former studies that acridine orange (139), ethidium bromide (140) and sodium dodecylsulphate $(141,142)$ affect plasmid replication. However, the acridine dyes and ethidium bromide could not be tested in vivo because of their mutagenicity, while sodium dodecylsulphate was excluded from in vivo trials because of its detergent action. There was a turning point on plasmid elimination experiments when it was observed that two well-known medicines, chlorpromazine and promethazine eliminated the tetracycline, chloramphenicol, streptomycin and sulphonamide resistance of an E. coli strain with a frequency of $30 \%(95)$. It is possible that inside the bacterial cells these drugs form an intermediate reversible complex with the plasmid DNA and gyrase or other topoismerase-like enzymes, in which the complex prevents the final step of plasmid stabilization in bacteria $(92,143)$. Concerning the isolated plasmid DNA, the open circular and linear forms of plasmid DNA were increased in promethazine treated samples, the supercoiled form disappeared $(89,94,99)$. In the case of the clinical strains investigated in this study (IV) as a result of the action of promethazine on plasmid DNA, complex formation was observed, the supercoiled form was missing, the intensity of the relaxed circular form decreased and the linear form of the plasmid DNA could be found in the best visible band (89). The results show that the majority of the clinical isolates contained various plasmids and some of them changed after 
treatment of plasmid DNA with plasmid curing compounds. Nevertheless it was surprising that tetracycline resistance could not be eliminated from the majority of the strains. It can be concluded that these polyresistant clinical isolates had a permeability barrier against curing compounds such as barriers (cell membrane) and increased efflux and that could be the reason of relatively weak plasmid elimination $(144,145,146,147)$. The tetracycline resistance genes causing increased efflux are localized either on plasmids or on the chromosome (136). The isolation of $\mathrm{Tc}^{\mathrm{r}}$ plasmid from clinical isolate E. coli 42883 and its retransfer clarified that the doxycycline resistance of this strain was encoded by $\mathrm{Tc}^{\mathrm{r}}$ plasmid.

The proton pump inhibitor [TF18] was able to modify the antibiotic resistance of bacteria. Most of the efflux proteins appear to reside in the lipid bilayer, with the hydrophilic amino acid loops protruding into the periplasmic and cytoplasmic space. The efflux proteins exchange a proton for a tetracycline-cation complex against a concentration gradient (151). The efflux genes from Gram-negative bacteria have two functional domains, $\alpha$ and $\beta$, which correspond to the $\mathrm{N}$ - and C-terminal halves of the protein, respectively (152). Mutations in either half of the protein eliminate resistance, suggesting that residues dispersed across the protein are important for function. More recently, combined mutagenic and labelling approaches have been used to probe topology and structure-function relationships in the Gram-negative MFS tetracycline transporter family. Mutations apparently affecting energy coupling have been located in cytoplasmic loops $2-3$ and $10-11$ of the efflux protein $(153,154)$ resulting in a conformational change.

Trifluoromethyl ketones are valuable compounds with biological interests, because they have potent antimicrobial activity against bacteria, yeasts, filamentous fungi and human immunodeficiency virus (HIV) $(155,156,157)$. Tricyclic compounds can have direct activity against bacteria and they are able to enhance the activity of antibiotics and to reverse antibiotic resistance (98).

Based on the effect of trifluoromethyl ketones studied earlier $(155,156,157)$ my attention focused on the combination of the trifluoromethyl ketone proton pump inhibitor TF18 with well known antiplasmid compounds such as promethazine, trifluoperazine and 9aminoacridine. The model strain of E. coli used in this study was E. coli K12 LE140 carrying F'lac metabolic plasmid (100,IV).

In the checkerboard studies the interaction between proton pump inhibitor and tricyclic compounds has been examined and it turned out that the interaction of proton pump inhibitor and trifluoperazine exerted synergistic effect on E. coli 42883 doxycycline resistant strain. The mechanisms by which the proton pump inhibitor TF18 could enhance the antibacterial 
activity of antiplasmid compounds can be explained by alteration of the membrane permeability caused by TF18. A possible explanation for the observed synergism is that the intracellular concentration of trifluoperazine and promethazine could be enhanced by proton pump inhibitor which can block many transporters using proton motive force.

The antiplasmid compounds form complexes with plasmid DNA (VII) and can also inhibit efflux pumps $(158,159)$. I conclude that the mechanism by which phenothiazines inhibit efflux of different substrates by proton motive force-dependent pumps is multifactorial and may affect the membrane potential. It has also been shown that the proton pump inhibitor increased the frequency of plasmid elimination, apparently due to structural and functional changes in the cell membrane $(161,162)$. The results presented suggest that inhibition of membrane transporters may be combined for plasmid curing of some antibiotic resistant bacteria and virulence of special pathogens like Helicobacter pylori.

It is known that the proton pump has a key role in the patogenicity related motility of some bacterial species (Helicobacter, E.coli), therefore the effect of proton pump inhibitor was studied on H. pylori. Helicobacter pylori is responsible for chronic gastritis, peptic ulcer and risk of development of stomach cancer $(120,121,122,123)$. Numerous virulence factors of H. pylori are encoded on pathogenicity island (124). Some proton pump inhibitors selectively block the bacterial multiplication in stomach via direct antibacterial effect. The target of these compounds is the proton motive force of bacteria, which is also responsible for the motility $(126,127)$. Today, the treatment of the infection is based on the use of triple therapies consisting of a combination of two antibiotics (clarithromycin, amoxicillin and/or metronidazole) with a proton pump inhibitor $(125,128)$.

The proton motive force is used by secondary MDR transporters as an energy source to drive drugs out of the cell $(63,168)$ and bacterial flagella. The rotary motor utilizes the free energy stored in the electrochemical proton gradient across the cytoplasmic membrane to do mechanical work (Figure 9. A.B.). The bacterial flagellar motor is a tiny molecular machine that uses a transmembrane flux of $\mathrm{H}^{+}$or $\mathrm{Na}^{+}$ions to drive flagellar rotation. In proton-driven motors, the membrane proteins MotA and MotB interact via their transmembrane regions to form a proton channel $(63,163,164,165)$.

Since it is known that motility is dependent on proton motive force across the cytoplasmic membrane $(166,167)$, the antibacterial and antimotility effect of TF18 was rational to study in details on Helicobacter pylori. The inhibition of the bacterial movement seemed to be a useful model to demonstrate the activity of proton pump for testing inhibitors. 
The proton pump inhibitor TF18 was able to inhibit the flagellar motor of both CSHP and CRHP isolates of Helicobacter pylori. The antimotility effect of TF18 was more significant at sub-inhibitory concentration in CRHP than in CSHP. Swimming was more sensitive to the inhibition than tumbling. It supposes that TF18 works as an un-coupler in biological motor. It suggests that TF18 decreased ATP synthesis acts as an un-coupler, when direct membrane damage might destroy the transmembrane proton gradient, and, consequently, the synthesis of ATP is inhibited. There is another opportunity, when TF18 inhibits the electron flow as electron acceptor in the transmembrane region that presents the establishment of the proton motive forces when electron transport linked to ATP synthesis is blocked.

Figure 9. A: Diagram of the flagellum in a Gram-negative bacterium. Gram-positive species lack the LP-ring assembly. Only a fraction of the full filament length is shown, as it is quite long on this scale (ca. $10 \mu \mathrm{m})$. OM, outer membrane; PG, peptidoglycan; IM, inner membrane.

B. Proteins that function in rotation. The MotA and MotB proteins form the stator complexes, anchored to the cell wall by a putative peptidoglycan-binding motif in the periplasmic domain of MotB. Each motor contains several (as many as eight) stator complexes, each with composition Mot $\mathrm{A}_{4}$ MotB $\mathrm{B}_{2}$. FliF does not function directly in rotation, but forms the MS-ring that is the mounting surface for the 'switch complex' comprising FliG, FliM, and FliN. FliG is known to contact the MS-ring directly, whereas FliM and FliN are somewhere farther down in the Cring.(Figure taken from Blair DF: Flagellar movement driven by proton translocation. FEBS Lett. 12;545(1)86-95, 2003.)

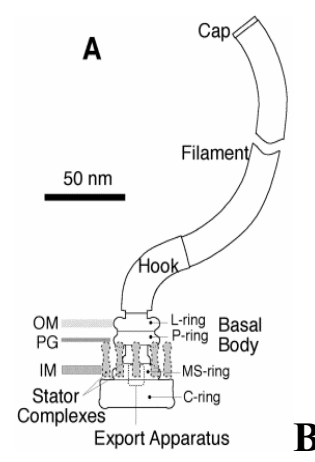

Due to the functional similarities of efflux model in bacteria and cancer cells, the reversal of multidrug resistance of mouse lymphoma cells was promising with synthetic and plant derived compounds. In case of benzo[b]-1,8-naphthyridine derivatives the great majority of the benzonaphthyridine derivatives showed higher activity than verapamil and these compounds increased the accumulation of Rhodamine 123 in MDR cells more efficiently than phenothiazine (169) and acridine derivatives studied earlier (170). Since the hydrophobic moiety of various compounds could be essential in the activity of MDR modulators (171), in my experiments benzonaphthyridine derivatives with different substitutions (polycyclic nucleus) were studied. Compounds with saturated side chain, e.g. which have saturated aza heterocyclic moieties (pyrrolidine, morpholine, piperidine), were the most active at the lowest concentration. The hydrophobicity of inhibitors of $\mathrm{ABC}$ transporters was shown in my experiments by studying various coumarin derivatives and my results correspond to other 
published results (171). The presence of the amino group protonable in the physiological conditions seemed to be necessary for the reversion of MDR in the case of tricyclic derivatives based on my results and of others $(89,172,173)$ ). It was found that the majority of pyridoquinoline derivatives, aza-oxafluorenes and pregnane derivatives were able to reduce the activity of P-glycoprotein. It is difficult to see a direct relationship between the effects of these compounds on MDR and their interaction with nucleic acids. Probably the interaction with DNA is unrelated to the MDR reversal effect. In addition to the compounds with well defined chemical structures various plant extracts such as persimmon extracts containing flavonoids, carotenoids $(174,175)$ were able to inhibit the $\mathrm{ABC}$ transporters of cancer cells also in my experiments. In addition to the inhibiton of ABC transporters of tumour cells, as an alternative cell death, the apoptosis induction was found in the presence of some resistance modifiers (cycloartanes) on mouse lymphoma cells, but was not significant $(\mathrm{V})$.

\section{NEW SCIENTIFIC RESULTS RELATED TO THE THESIS}

Various resistance mechanisms such as complex formation with DNA, ABC-and proton transporters were modified in bacteria and cancer cells by synthetic and natural compounds.

\section{Antimicrobial effect of tricyclic compounds}

From the tricyclic compounds 9-aminoacridine exerted the most potent antibacterial effect on clinical isolates, furthermore trifluoperazine had stronger antibacterial activity than promethazine due to its higher electronegativity.

\section{Plasmid elimination by tricyclic compounds}

The mechanism of antiplasmid effect of promethazine, trifluoperazine and 9-aminoacridine were studied on doxycycline resistant enteric bacteria. The doxycycline resistant clinical $E$. coli strains were less sensitive for the plasmid elimination by tricyclic compounds than the laboratory F'lac strain. In addition there was a difference between the curing effect of promethazine and trifluoperazine and there were clinical isolates, from which the doxycycline resistance could be hardly eliminated. It can be concluded that the plasmid elimination cannot be applied alone as a new approach for treatment infections caused by multidrug resistant bacteria, but if plasmid curing compounds are combined with other agents (e.g. inhibitors of $\mathrm{ABC}$ - or proton transporters), which can increase the intracellular drug concentration, the curing efficacy can be increased. 


\section{Interactions of antiplasmid compounds with plasmid DNA}

The effect of antiplasmid compounds on plasmid profiles was analyzed by agarose gel electrophoresis and spectrophotometry.

- Pyrido[3,2-g] quinoline derivatives had binding affinities to calf thymus and plasmid DNA due to complex formation. The binding properties of pregnane derivatives have been found weaker; the aza-oxafluorenes seemed to be ineffective in complex formation with DNA.

- The majority of the clinical isolates contained plasmids. Complex formation was shown between the isolated plasmid DNA and antiplasmid compounds such as promethazine and 9aminoacridine. The doxycycline resistance could be eliminated from some of these strains with low frequency due the permeability barriers of the cell membrane and increased efflux.

- From one of the clinical strain E. coli 42883 the tetracycline resistance plasmid was isolated, identified and the plasmid was retransformed into E. coli DH5 $\alpha$ strain. Evidence was proved that the doxycycline resistance was encoded by plasmid.

IV. The effect of proton pump inhibitor (1-(2-benzoxazolyl)-3,3,3-trifluoro-2-propanone [TF18]) on the action of resistance modifiers in model experiments

- Interaction between proton pump inhibitor and antiplasmid compounds from the aspect of antibacterial effect

In checkerboard studies the interaction with proton pump inhibitor and tricyclic compounds (promethazine, trifluoperazine, 9-aminoacridine) was additive in the antibacterial action on the model and clinical strain of E. coli. The combination TF18 and trifluoperazine exerted synergistic effect on a clinical isolate.

- Interaction between proton pump inhibitor and antiplasmid compounds from the aspect of antiplasmid effect

The proton pump inhibitor increased the frequency of plasmid elimination of promethazine, trifluoperazine and 9-aminoacridine on the model and clinical strain of E. coli.

- Specific effect of proton pump inhibitor on a model of Helicobacter pylori: antibacterial and antimotility studies

The inhibition of the bacterial motility seemed to be a useful model to demonstrate the activity of proton motive force in the presence of trifluoromethyl ketone. The proton pump inhibitor TF18 was able to inhibit the flagellar motor of both clarithromycin sensitive and clarithromycin resistant isolates of Helicobacter pylori. The antimotility effect of trifluoroketone was more pronounced at sub-inhibitory concentration in the resistant strain than in the sensitive one. Swimming was more sensitive to the inhibition than tumbling. It can be supposed that TF18 works as an un-coupler in biological motor. 


\section{Reversal of multidrug resistance of mouse lymphoma cells with synthetic and plant derived compounds}

The synthetic benzo[b]-1,8-naphthyridine, pyridoquinoline, aza-oxafluorene, and pregnane derivatives were tested on the drug accumulation of human MDR1 gene transfected mouse lymphoma cells by using a standard functional assay with rhodamine 123. From natural compounds coumarin derivatives and persimmon extracts were shown as potent resistance reversal agents in human MDR1 gene transfected mouse lymphoma cells. Numerous compounds tested reversed the MDR of the tumour cells more effectively than the reference drug verapamil.

\section{Apoptosis induction of resistance modifiers on mouse lymphoma cells}

Some resistance modifiers e.g. cycloartanes were very weak apoptosis inducers.

\section{SUMMARY}

The main aim of the thesis was to investigate the drug resistance reversal on prokaryotic and eukaryotic model organisms. Based on DNA and protein complex formation properties of the given compounds the plasmid elimination of bacteria and the modification of the drug transporter proteins, various experimental systems have been studied in bacteria and tumor cells.

It was found that $E$. coli cells isolated from clinical specimen were less sensitive for the plasmid elimination than the laboratory strain carrying F prime plasmid, however there was a complex formation between the antiplasmid compounds and the plasmid DNA isolated from both the clinical and laboratory strains. In addition there was a difference between the curing effect of two phenothiazines - the PMZ and TFP - on some E. coli strains in this study.

The mechanism of action of different antiplasmid compounds was investigated on model nucleic acids such as calf thymus DNA and plasmid DNA. The pyrido[3,2-g] quinoline and phenothiazine derivatives seemed to have a complex formation with the model nucleic acids. Some of the compounds modified the activity of membrane efflux proteins.

Based on the effect of trifluoromethyl ketones studied earlier my attention was focused on the combination of the trifluoromethyl ketone proton pump inhibitor TF18 with well known antiplasmid compounds such as promethazine, trifluoperazine and 9-aminoacridine. In the checkerboard studies the interaction between proton pump inhibitor and tricyclic compounds has been examined and it turned out that the interaction of proton pump inhibitor 
and trifluoperazine exerted synergistic antibacterial and plasmid curing effect on $E$. coli doxycycline resistant clinical strain due to alteration of activity of membrane transporters.

The role of proton pump system of bacterial membrane was studied on Helicobacter pylori strains. The trifluoroketone proton pump inhibitor was able to block the proton motive forces and the activity of flagellar motor of both clarithromycin sensitive and resistant isolates of Helicobacter pylori. Since swimming was more sensitive to the inhibition than tumbling, I can suppose that TF18 works as an un-coupler in biological motor.

The sensitivity of MDR1 type of eukaryotic ABC-transporter to resistance modifiers was studied on cancer cells. The synthetic benzo[b]-1,8-naphthyridine, pyridoquinoline, azaoxafluorene and pregnane derivatives exerted reversing action of P-glycoprotein 170. Furthermore natural compounds, like coumarin derivatives and some fractions of persimmon extracts have been found to be potent resistance reversal agents against tumour cells.

\section{ÖSSZEFOGLALÓ}

A disszertáció fő célja a rezisztencia visszafordításának vizsgálata prokarióta és eukarióta modelleken. A vizsgálandó anyagok DNS-sel és fehérjével való komplexképző tulajdonságait alapul véve különféle kísérleti rendszerekben vizsgáltam a plazmidtörlést baktériumokban, valamint tanulmányoztam a transzporter fehérjék müködését baktériumokban és tumorsejtekben.

A klinikai mintákból származó $E$. coli törzsek kevésbé voltak érzékenyek a plazmidtörlésre, mint az F prime plazmidot hordozó laboratóriumi E. coli törzs, bár mindkét esetben kimutatható volt a komplexképzés az antiplazmid vegyületek és a törzsekből izolált plazmid DNS között. Továbbá a promethazin és a trifluoperazin plazmidtörlő hatása is különböző volt néhány $E$. coli törzsnél.

A különféle antiplazmid vegyületek hatásmechanizmusát modell nukleinsavakon, borjú thymus DNS-en és plazmid DNS-en vizsgáltam. A pyrido[3,2-g] quinolin és fenotiazin származékok esetében komplexképződést mutattam ki a modell nukleinsavakkal. Néhány vegyület pedig a membrán efflux proteinek aktivitását módosította.

A trifluoroketonok hatására vonatkozó korábbi irodalmi adatok alapján a trifluorometil-keton proton pumpa gátlót (TF18) jól ismert antiplazmid hatású anyagokkal, promethazinnal, trifluoperazinnal és 9-aminoakridinnal kombináltam. Checkerboard vizsgálatokkal jellemeztem a proton pumpa gátló és a triciklusos vegyületek kölcsönhatását, és arra az eredményre jutottam, hogy a proton pumpa gátló TF18-trifluoperazin kombináció 
szinergista antibakteriális és antiplazmid hatású volt a doxycyclin rezisztens klinikai E. coli törzsön a membrán transzporterek aktivitásának megváltoztatása miatt.

A baktérium membrán proton pumpa rendszerének szerepét Helicobacter pylori törzseken tanulmányoztam. A trifluoroketon proton pumpa gátló csökkenteni tudta a proton motoros erőket és a flagelláris motor aktivitását mind a clarithromycin érzékeny, mind a clarithromycin rezisztens Helicobacter pylori izolátumokon. Az úszó mozgás sokkal jobban volt gátolható, mint a bukfencező; feltételezhetö, hogy a TF18 szétkapcsolóként müködik a biológiai motorban.

Az eukarióta membrán transzporterek, szükebben az ABC-transzporter rezisztencia módosítókra mutatott érzékenységét vizsgáltam rákos sejteken. A szintetikus benzo[b]-1,8naphthyridin, pyridoquinolin, aza-fluorén és pregnán származékok rezisztencia visszafordító hatásúak voltak P-gp 170-en. Ezenkívül a természetes anyagok mint a kumarin származékok és a persimmon kivonatok néhány frakciója hatásos rezisztencia módosítónak bizonyult tumorsejteken.

\section{REFERENCES}

1. Fleming A: Penicillin. Nobel lecture, December 11, 1945. Available from www.nobelprize.org/medicine/laureates/1945/fleming-lecture.pdf2.

2. Watanabe T: Infective heredity of multiple drug resistance in bacteria. Bacteriol Rev. 27(1): 87115. 1963.

3. Weber JT, Courvalin P: An emtying quiver: antimicrobial drugs and resistance. Emerging Infectious Diseases Vol 11(6) 791-793 2005.

4. Harbarth S, Samore MH: Antimicrobial resistance determinants and future control. Emerging Infectious Diseases Vol 11(6) 794-801 2005.

5. Amábile-Cuevas CF, Chicurel ME: Bacterial plasmids and gene flux. Cell 189-99, 1992.

6. Livermore, DM: Bacterial resistance: origins, epidemiology and impact. Clinical Infectious Diseases 36:S11-S23, 2003.

7. Stratton CW . Dead bugs don't mutate: susceptibility issues in the emergence of bacterial resistance. Emerg Infect Dis Vol 9 (1)10-16, 2003.

8. Guiney DG: Promiscuous transfer of drug resistance in Gram-negative bacteria. The Journal of Infectious Diseases, 149: 320-329, 1984.

9. Llosa M, Gomis-Rüth XF, Coll M, de la Cruz F: Bacterial conjugation: a two-step mechanism for DNA transport. Mol Microbiol. 45(1):1-8, 2002.

10. Szpirer C, Top E, Couturier M, Mergeay M: Retransfer or gene capture: a feature of conjugative plasmids, with ecological and evolutionary significance. Microbiology (145)3321-3329, 1999.

11. Noirot P, Noirot-Gros MF: Protein interaction network in bacteria. Current Opinion in Microbiology 7:55-512, 2004.

12. Espinosa M, del Solar G, Rojo F, Alonso JC: Plasmid rolling circle replication and its control. FEMS Microbiol Lett. 130(2-3):111-20. 1995.

13. Lacey RW: Evolution of microorganisms and antibiotic resistance. The Lancet, 2(8410): 10221025. 1984.

14. McManus MC: Mechanisms of bacterial resistance to antimicrobial agents. Am J Health-Syst Pharm 54:1420-1433, 1997. 
15. Chen I, Dubnau D: DNA uptake during bacterial transformation. Nature Reviews Microbiology Vol 2:241-249, 2004.

16. Maiden MC: Horizontal genetic exchange, evolution, and spread of antibiotic resistance in bacteria. Clin Infect Dis Suppl 1:S12-20, 1998.

17. Cirz RT, Chin JK, Andes DR, de Crécy-Lagard V, Craig WA, et al: Inhibition of mutation and combating the evolution of antibiotic resistance. PloS Biol 3(6):e176 2005.

18. Kapil A: The challenge of antibiotic resistance: need to contemplate. Indian J Med Res 121:8391, 2005.

19. Amyes SGB: Genes and spectrum: the theoretical limits. Clin Infect Dis Suppl 1:S21-28, 1998.

20. Havecker ER, Gao X, Voytas DF: The diversity of LTR retrotransposons. Genome Biology 5(6):225-231, 2004.

21. Oelschlaeger TA, Hacker J: Impact of pathogenicity islands in bacterial diagnostics. APMIS 112:930-6, 2004.

22. Ochman H, Moran NA: Genes lost and genes found: evolution of bacterial pathogenesis and symbiosis. Science Vol 292 Issue 5519, 1096-1099, 2001.

23. Sundsfjord A et al: Genetic methods for detection of antimicrobial resistance APMIS 112:81537, 2004.

24. Poole K: Overcoming antimicrobial resistance by targeting resistance mechanisms. Journal of Pharmacy and Pharmacology 53:283-294, 2001.

25. Davies J: Inactivation of antibiotics and the dissemination of resistance genes. Science, 264 : 375-382, 1994.

26. Nikaido H: Antibiotic resistance caused by Gram-negative multidrug efflux pumps. Clin Infect Dis Suppl 1S32-S41, 1998.

27. Madigan MT, Martinko JM, Parker J: Brock Biology of Microorganisms, Eighth Edition, Prentice-Hall Inc., p.196, p.328-333, 1997.

28. Matson SW, Ragonese H: The F-plasmid TraI protein contains three functional domains required for conjugative DNA strand transfer. J Bacteriol. 187(2):697-706, 2005.

29. Masson L, Ray DS: Mechanism of autonomous control of the F plasmid: purification and characterization of the repE gene product. Nucleic Acids Res. January 25; 16(2): 413-424m, 1988.

30. Smit E, Wolters A, van Elsas JD: Self-Transmissible Mercury Resistance Plasmids with GeneMobilizing Capacity in Soil Bacterial Populations: Influence of Wheat Roots and Mercury Addition. Appl Environ Microbiol Vol 64(4)1210-1219, 1998.

31. Khan AU, Musharraf A: Plasmid-mediated multiple antibiotic resistance in Proteus mirabilis isolated from patients with urinary tract infection. Med Sci Monit. 10(11):CR598-602, 2004.

32. Riley MA et al: The newly characterized colicin Y provides evidence of positive selection in pore-former colicin diversification. Microbiology 146:1671-1677, 2000.

33. Jerman B, Butala M, Zgur-Bertok D: Sublethal concentrations of ciprofloxacin induce bacteriocin synthesis in Escherichia coli. Antimicrob Agents Chemother. 49(7):3087-90, 2005.

34. Clarke SC, Haigh RD, Freestone PP, Williams PH.: Virulence of enteropathogenic Escherichia coli, a global pathogen. Clin Microbiol Rev. 16(3):365-78, 2003.

35. Yamaguchi $\mathrm{T}$ et al: Complete Nucleotide Sequence of a Staphylococcus aureus Exfoliative Toxin B Plasmid and Identification of a Novel ADP-Ribosyltransferase, EDIN-C. Infection and Immunity, December, Vol. 69(12) p. 7760-7771, 2001.

36. Sirard JC, Mock M, Fouet A: The three Bacillus anthracis toxin genes are coordinately regulated by bicarbonate and temperature. J Bacteriol. 176(16): 5188-5192, 1994.

37. Otten L, De Ruffray P: Agrobacterium vitis nopaline Ti plasmid pTiAB4 : relationship to other Ti plasmids and T-DNA analysis. Mol. Gen. Genet. 245:493-505, 1994.

38. LeBlanc DJ, Crow VL, Lee LN, Garon CF Influence of the lactose plasmid on the metabolism of galactose by Streptococcus lactis. J Bacteriol. 137(2):878-84, 1979.

39. Hardesty C, Colon G, Ferran C, DiRienzo JM. Deletion analysis of sucrose metabolic genes from a Salmonella plasmid cloned in Escherichia coli K12. Plasmid. 18(2):142-55, 1987.

40. Williams PA: Catabolic plasmids: fast-track bacterial evolution to combat pollution. Microbiology Today Vol 31 Nov 168-170, 2004. 
41. Ahmad G: Biodiversity and performance of Rhizobia in relation to plasmid genes and their translation products. OnLine Journal of Biological Sciences 1(12):1134-1137, 2001.

42. Moreira MA, de Souza EC, de Moraes CA: Multidrug efflux systems in Gram-negative bacteria. Brazilian Journal of Microbiology, 35:19-28, 2004.

43. Lewis K.: Multidrug resistance pumps in bacteria: variations on a theme. Trends Biochem Sci. Mar;19(3):119-23, 1994.

44. Roberts MC. Tetracycline resistance determinants: mechanisms of action, regulation of expression, genetic mobility, and distribution. FEMS Microbiol Rev, 19:1-24, 1996.

45. Nikaido H: Multidrug efflux pumps of Gram-negative bacteria. J Bacteriol, 178:5853-5859, 1996.

46. Putman M, van Veen HW, Konings WN: Molecular properties of bacterial multidrug transporters. Microbiol Mol Biol Rev. 64(4):672-93, 2000.

47. Marger M, Saier MH Jr. A major superfamily of transmembrane facilitators that can catalyze uniport, symport and antiport. Trends Biochem Sci,18:13-20, 1993.

48. Borges-Walmsley MI, Beauchamp J, Kelly SM, Jumel K, Candlish D, Harding SE, Price NC, Walmsley AR: Identification of oligomerization and drug-binding domains of the membrane fusion protein EmrA. J Biol Chem. 278(15):12903-12, 2003.

49. Kaatz GW, Seo SM: Effect of substrate exposure and other growth condition manipulations on norA expression. J Antimicrob Chemother. 54(2):364-9, 2004.

50. Brown MH, Skurray RA. Staphylococcal multidrug efflux protein QacA. J Mol Microbiol Biotechnol. 3(2):163-70, 2001.

51. Dalmas O, Do Cao MA, Lugo MR, Sharom FJ, Di Pietro A, Jault JM: Time-resolved fluorescence resonance energy transfer shows that the bacterial multidrug $\mathrm{ABC}$ half-transporter BmrA functions as a homodimer. Biochemistry, 22;44(11):4312-21. 2005.

52. De Rossi E, Branzoni M, Cantoni R, Milano A, Riccardi G, Ciferri O: mmr, a Mycobacterium tuberculosis Gene Conferring Resistance to Small Cationic Dyes and Inhibitors. J Bacteriol. 180(22): 6068-6071, 1998.

53. Paulsen IT, Littlejohn TG, Radstrom P, Sundstrom L, Skold O, Swedberg G, Skurray RA: The 3' conserved segment of integrons contains a gene associated with multidrug resistance to antiseptics and disinfectants. Antimicrob Agents Chemother, 37:761-768, 1993.

54. Rotem D, Schuldiner S.: EmrE, a multidrug transporter from Escherichia coli, transports monovalent and divalent substrates with the same stoichiometry. J Biol Chem. 19;279(47):48787-93, 2004.

55. Murakami S, Tamura N, Saito A, Hirata T, Yamaguchi A. Extramembrane central pore of multidrug exporter AcrB in Escherichia coli plays an important role in drug transport. J Biol Chem. 30;279(5):3743-8, 2004.

56. Yu EW, Aires JR, Nikaido H: AcrB multidrug efflux pump of Escherichia coli: composite substrate-binding cavity of exceptional flexibility generates its extremely wide substrate specificity. Journal of Bacteriology 185(19)5657:5664, 2003.

57. Eda S, Yoneyama H, Nakae T: Function of the MexB efflux-transporter divided into two halves. Biochemistry. 17;42(23):7238-44, 2003.

58. Hagman KE, Lucas CE, Balthazar JT, Snyder L, Nilles M, Judd RC, Shafer WM: The MtrD protein of Neisseria gonorrhoeae is a member of the resistance/nodulation/division protein family constituting part of an efflux system Microbiology, Vol 143, 2117-2125, 1997.

59. Morita Y, Kodama K, Shiota S, Mine T, Kataoka A, Mizushima T, Tsuchiya T: NorM, a Putative Multidrug Efflux Protein, of Vibrio parahaemolyticus and Its Homolog in Escherichia coli. Antimicrobial Agents and Chemotherapy, Vol. 42(7): 1778-1782, 1998.

60. Borges-Walmsley IM, McKeegan KS, Walmsley AR: Structure and function of efflux pumps that confer resistance to drugs. Biochem. J. 376:313-338, 2003.

61. Paulsen IT, Brown MH, Skurray RA: Proton-dependent multidrug efflux systems. Microbiol Rev, Dec 575-608, 1996.

62. Schweizer HP: Efflux as a mechanism of resistance to antimicrobials in Pseudomonas aeruginosa and related bacteria: unanswered questions.Genet. Mol. Res. 2 (1): 48-62, 2003.

63. Kojima S, Blair DF: The bacterial flagellar motor: structure and function of a complex molecular machine. Int Rev Cytol 233:93-134. 2004. 
64. Blair DF: Flagellar movement driven by proton translocation. FEBS Lett. 12;545(1):86-95, 2003.

65. Bardy SL, Ng SY, Jarrell KF: Prokaryotic motility structures. Microbiology 149(Pt 2):295-304, 2003.

66. Berg HC: The rotary motor of bacterial flagella. Annu Rev Biochem.72:19-54, 2003.

67. Kenny B, Taylor S, Holland IB: Identification of individual amino acids required for secretion within the haemolysin(HlyA) C-terminal targeting region. Mol Microbiol. 6:1477-1489, 1992.

68. Gerlach JH, Endicott JA, Juranka PF, Henderson G, Sarangi F, Deuchars KL, Ling V: Homology between P-glycoprotein and a bacterial haemolysin transport protein suggests a model for multidrug resistance. Nature. Dec 4-10;324(6096):485-9, 1986.

69. Kránitz L, Benabdelhak H, Horn C, Blight MA, Holland BI, Schmitt L: Crystallization and preliminary X-ray analysis of the ATP-binding domain of the ABC transporter haemolysin B from Escherichia coli. Acta Crys D58, 539-541, 2002.

70. Molnar J, Hever A, Fakla I, Fischer J, Ocsovski I, Aszalos A: Inhibition of the transport function of membrane proteins by some substituted phenothiazines in E. coli and multidrug resistant tumor cells. Anticancer Res. 17(1A):481-6, 1997.

71. Tribe MJ, Pinney RJ: Cyclic thymineless death significantly increases frequency of R-plasmid elimination. Antimicrob Agents and Chemother 4:555-556, 1977.

72. Szabo D, Keyzer H, Kaiser H.E, Molnar J: Reversal of multidrug resistance of tumor cells. Anticancer Res. 20, 4261-4274, 2000.

73. Higgins CF, Linton KJ: The ATP switch model for ABC transporters. Nature Structural \& Molecular Biology, Vol 11(10), 918-926, 2004.

74. Hoffmann U, Kroemer HK: The ABC transporters MDR1 and MRP2: multiple functions in disposition of xenobiotics and drug resistance. Drug Metab Rev. 36(3-4):669-701, 2004.

75. Leslie EM, Deeley RG, Cole SP: Toxicological relevance of the multidrug resistance protein 1, MRP1 (ABCC1) and related transporters. Toxicology. Oct 5;167(1):3-23, 2001.

76. Haimeur A, Conseil G, Deeley RG, Cole SP: The MRP-related and BCRP/ABCG2 multidrug resistance proteins: biology, substrate specificity and regulation. Curr Drug Metab. 5(1):21-53, 2004.

77. Leslie EM, Deeley RG, Cole SP: Multidrug resistance proteins: role of P-glycoprotein, MRP1, MRP2, and BCRP (ABCG2) in tissue defense. Toxicol Appl Pharmacol. May 1;204(3):216-37, 2005.

78. Bauer B, Hartz AM, Fricker G, Miller DS: Modulation of p-glycoprotein transport function at the blood-brain barrier. Exp Biol Med (Maywood). 230(2):118-27. 2005.

79. Liu L, Pang KS: The roles of transporters and enzymes in hepatic drug processing. Drug Metab Dispos. 33(1):1-9, 2005.

80. Cufer T, Pfeifer M, Vrhovec I, Frangez R, Kosec M, Mrhar A, Grabnar I, Golouh R, Vogric S, Sikic BI: Decreased cortisol secretion by adrenal glands perfused with the P-glycoprotein inhibitor valspodar and mitotane or doxorubicin. Anticancer Drugs. 11(4):303-9, 2000.

81. Ambudkar SV, Dey S, Hrycyna CA et al.: Biochemical, cellular and pharmacological aspects of the multidrug transporter. Annu. Rev. Pharmacol. Toxicol. 39:361-98, 1999.

82. Higgins CF: ABC transporters: physiology, structure and mechanism--an overview. Res Microbiol. 152(3-4):205-10, 2001.

83. Gottesman MM: Mechanisms of cancer drug resistance. Annu Rev Med. 53:615-27, 2002.

84. Lage $\mathrm{H}$ : ABC-transporters: implication on drug resistance from microorganisms to human cancers. Int J Antimicrob Agents 22:188-199, 2003.

85. Gottesman MM, Pastan I.: Biochemistry of multidrug resistance mediated by the multidrug transporter. Annu. Rev. Biochem. 62:385-427, 1993.

86. Mándi Y, Molnár J, Holland IB, Béládi I: Efficient curing of an Escherichia coli F-prime plasmid by phenothiazines. Genet. Res., Camb. 26, 109-111, 1976.

87. Molnár J, Nakamura MJ: Virulence associated plasmid and R-plasmid curing in Yersinia enterocolitica by some tricyclic compounds.Acta Microbiol. Hung. 35, 309-314, 1988.

88. Csiszár K, Molnár J: Mechanism of tricyclic drugs on Escherichia coli and Yersinia enterocolitica plasmid maintenance and replication. Anticancer Res. 12, 2267-2272, 1992.

89. Molnár J, Földeák S, Nakamura MJ, Rausch H, Domonkos K, Szabó M: Antiplasmid activity: 
loss of bacterial resistance to antibiotics. APMIS Suppl. XXX/100, 25-32, 1992.

90. Molnar A, Amaral L, Molnar J: Antiplasmid effect of promethazine in mixed bacterial cultures. Int J Antimicrob Agents. 22:217-22, 2003.

91. Molnár J: The role of charge distribution of tricyclic compounds in the antibacterial, antiviral and antiplasmid effects.In: Electropharmacology, eds. N. Keyzer, F. Gutmann, G. Eckert; CRC, pp. 205-219, 1990.

92. Molnár J., Földeák S., Nakamura M.J., Gaizer F., Gutmann F: The influence of charge transfer complex formation on the antibacterial activity of some tricyclic drugs. Xenobiotica 21, 309$319,1991$.

93. Molnár J, Gálfi M, Lózsa A, Nakamura MJ: Inhibition of bacterial plasmid replication by stereoselective binding of tricyclic psychopharmacons. Res. Commun. Chem. Pathol. Pharmacol. 43, 235-249, 1984.

94. Molnár J: Antiplasmid activity of tricyclic compounds. Meth. Find. Exp. Clin. Pharmacol. 10/7, 467-474, 1988.

95. Molnár J, Király J, Mándi Y: The antibacterial action of R-factor inhibiting activity by chlorpromazine.Experientia 31, 444-445, 1975.

96. Molnár J, Bathó $\mathrm{N}$, Csik V, Chevalier J, Cremieux A: Interaction between tricyclic psychopharmacons and antibiotics. Acta Microbiologica Hung. 40, 91-99, 1993.

97. Hinnebusch J, Barbour AG: Linear- and circular-plasmid copy numbers in Borrelia burgdorferi. J Bacteriol. 174(16): 5251-5257, 1992.

98. Barabás K, Molnár J: Lack of correlated between intercalation and plasmid curing ability of some tricyclic compounds. Acta Microbiol. Acad. Sci. hung. 27, 55-61, 1980.

99. Molnár J, Mándi Y, Földeák S: Drug-receptor interaction on plasmid elimination by phenothiazines and imipramine in Escherichia coli. Acta microbiol. Acad. Sci. hung. 29, 17-25, 1982.

100. Miskolci Cs, Labádi I, Kurihara T, Motohashi N, Molnár J: Guanine-cytosine rich regions of plasmid DNA can be the target in anti-plasmid effect of phenothiazines. Int. J. Antimicrob. Agents 14, 243-247, 2000.

101. Kurihara T, Motohashi N, Kobayashi H, Yamanaka W, Dohyashki S-I, Molnár J: Interaction of chlorpromazine with 2'-deoxyguanosine-5'-monophosphate by PM3 calculation.Anticancer Res. 18, 3493-3498, 1998.

102. Szabó M, Molnár J, Bánfalvi Zs, Motohashi N: Inhibition of tumor induction by Agrobacterium tumefaciens and nodulation induced by Rhisobium meliloti in the presence of phenothiazines and structurally related compounds.Anticancer Res. 12, 1667-1670, 1992.

103. Mándi Y, Molnár J: Effect of chlorpromazine on conjugal plasmid transfer and sex pili.Acta microbiol. Acad. Sci. hung. 28, 205-210, 1981.

104. Molnár J, Mucsi I, Kása P:Inhibition of the adhesion of E. coli on cultured human epithelial cells in the presence of promethazine or imipramine.Zbl. Bakt. Hyg., I. Abt. Orig. A 254, 388396, 1983.

105. Molnár J, Haszon I, Bodrogi T, Martonyi E, Turi S: Synergistic effect of promethazine with Gentamycin in frequently reccurring pyelonephritis.Int. J. Urol. Nephrol. 22/5, 405-411, 1990.

106. Farkas S, Molnár J: Elimination of F'lac plasmid by different psychotropic drugs and some related compounds. Acta Microbiol Acad Sci Hung 26, 351-361, 1979.

107. Kásler M, Molnár J, Ágoston E, Poczik M: A Gentamycin-Pipolphen gyógyszer-kombináció alkalmazásának tapasztalatai polyresistens baktériumtörzsek okozta urogenitális fertőzésekben.Urol. Nephrol. Szle. 9/3, 135-138, 1982.

108. Kásler M, Molnár J, Poczik M: A Pipolphen plazmidtörlő hatásának vizsgálata urogenitális fertőzések esetén.Urol. Nephrol. Szle. 9/3, 130-133, 1982.

109. Kawase M, Tanaka T, Sohara Y, Tani S, Sakagami H, Hauer H, Chatterjee SS: Structural requirements of hydroxylated coumarins for in vitro anti-Helicobacter pylori activity. Anticancer Res 23:3243-3246, 2003.

110. Alföldi L, Raskó I, Kerekes E. L-serine deaminase of E. coli. Journal of Bacteriology 96:151218,1968

111. McCoy TA, Maxwell M, Kruse PF: Amino acid requirement of the Novioff hepatoma in vitro. Proc.Soc. Exp.Biol.Med. 100:115-118, 1959. 
112. Wakata S, Grace JT: Cultivation in vitro of myeloblasts from human leukemia. New York State Journal of Med. 64:2279-2282, 1964.

113. Lorian, Victor (Editor): Antibiotics in laboratory medicine. $3^{\text {rd }}$ ed. Williams\&Wilkins, Baltimore, pp.72-75, 1991.

114. Lederberg, J, Lederberg, EM: Replica plating and indirect selection of bacterial mutants. J. Bact. 63: 399-406, 1952.

115. Birnboim HC, Doly J: A rapid alkaline extraction procedure for screening recombinant plasmid DNA. Nucleic Acids Res 7:1513-1523, 1979.

116. Eliopoulos, GM and Moellering, RC: Antimicrobial combinations. In: Victor, L (ed.): Antibiotics in Laboratory Medicine. $3^{\text {rd }}$ edition, Baltimore, Maryland, USA pp. 434-441, 1991.

117. Motohashi N, Sakagami H, Kurihara T, Ferenczy L, Csuri K, Molnár J: Antimicrobial activity of phenothiaziens, benzo(a)phenothiazines and benz(c)acridines. Anticancer Res 12:1207-10, 1992.

118. Koopmann G, Rentelinger CP, Kuijten Ga, Koehnen RM, Pals ST and Van Oers MH: Annexin $\mathrm{V}$ flow cytometric detection of phosphatidyl-serine expression on B cells undergoing apoptosis. Blood 84: 1115-1120, 1994

119. Molnár J, Földeák S, Tanaka M. Antibacterial activity of phenothiazines: Part I-effects on bacteria. In: "Non Antibiotics. National Institute of Science Communication (NISCOM)", Chakrabarty AN, Molnár J, Dastidar SG, Motohashi N. (Editors) New Delhi. India, p.100-113, 1998.

120. Shang J, Peña AS: Multidisciplinary approach to understand the pathogenesis of gastric cancer. World J Gastroenterol 21;11(27):4131-4139, 2005.

121. McLoughlin RM, O'Morain CA, O'Connor HJ: Eradication of Helicobacter pylori: recent advances in treatment. Fundam Clin Pharmacol. 19(4):421-7, 2005.

122. Suerbaum S, Achtman M: Helicobacter pylori recombination, population structure and human migrations. International Journal of Medical Microbiology 294:133-139, 2004.

123. Dunn BE, Cohen, Blaser MJ: Helicobacter pylori. Clinical Microbiology Reviews 21(4) 720$741,1997$.

124. Radosz-Komoniewska H, Bek T, Jozwiak J, Martirosian G. Pathogenicity of Helicobacter pylori infection. Clin Microbiol Infect 11(8):602-10, 2005.

125. Janssen MJR, Van Oijen AHAM, Verbeek ALM. et al. A systematic comparison of triple therapies for treatment of Helicobacter pylori infection with proton pump inhibitor/ranitidine bismuth citrate plus clarithromycin and either amoxicillin or a nitroimidazole. Aliment Pharmacol Ther15 613-624, 2001.

126. Schreiber S, Stuben M, Josenhans C, Scheid P, Suerbaum S: In Vivo Distribution of Helicobacter felis in the Gastric Mucus of the Mouse: Experimental Method and Results. Infect Immun 67(10): 5151-5156, 1999.

127. Niehus E, Ye F, Suerbaum S, Josenhans C: Growth phase-dependent and differential transcriptional control of flagellar genes in Helicobacter pylori. Microbiology 148: 3827-3837, 2002.

128. Robinson M: Proton pump inhibitors: update on their role in acid-related gastrointestinal diseases. Int J Clin Pract. 59(6):709-15, 2005.

129. Ordway D, Viveiros M, Leandro C, and Amaral L: Clinical concentrations of Thioridazine kill intracellular Multi-drug resistant Mycobacterium tuberculosis. Antimicrob Agents Chemother 47:917-922, 2003.

130. Amaral L, Kristiansen JE, Thomsen VF and Markowich B: The effect of chlorpromazine on the outer cell wall constituents of Salmonella typhimurium ensuring resistance to the drug. Int. J. Antimicrob. Agents 14:225-229, 2000.

131. Chen C, Clark D, Ueda k, Pastant I, Gottesman MM, Roninson IB: Genomic organization of the human multidrug resistance (MDR1) gene and origin of P-glycoproteins. Journal of Biological Chemistry 265(1)506-514, 1990.

132. Sioud M, Forterre P and de Recondo A: Effects of the antitumor drug VP16 (etoposide) on the archebacterial Halobacterium GRB 1.7 kb plasmid in vivo. Nuclei Acids Res 15:8217-8234, 1987. 
133. Elian Y: Effects of phenothiazines on the inhibition of plasma membrane ATP ase and hyperpolarization of cell membranes in the yeast Saccharomyces cerevisiae.Biochim Biophys Acta 769:601-610, 1984.

134. Hirouchi $\mathrm{H}$, Tagaki $\mathrm{M}$ and Yani K: Relaxation of supercoiled plasmid DNA by oxidative stresses in Escherichia coli. J Bact 160:1017-1021, 1974.

135. Ed by A.N. Chakrabarty (ed.), J. Molnár S.G. Dastidar, N. Motohashi, Non Antibiotics. A New Class of Unrecognised Antimicrobics. Antibacterial activity of phenothiazines: Part II-Effects on chromosomal DNA and physicochemical nature of drug binding. Nat. Inst. Sci. Commun. (CSIR) New Delhi, India pp.114-138, 1998.

136. Chopra I, Roberts MC. Tetracycline antibiotics: mode of action, applications, molecular biology, and epidemiology of bacterial resistance. Microbiol Mol Biol Rev; 65:232-60, 2001.

137. Roberts MC: Tetracycline therapy: update. Clinical Infectious Diseases 36:462-467, 2003.

138. Roberts MC: Update on acquired tetracycline resistance genes. FEMS Microbiol Lett 15;245(2):195-203, 2005.

139. Hirota Y: Effect of acridine dyes on mating type factors in E.coli. Proc Natl Acad Sci USA; 46:57, 1960.

140. Watanabe T, Nishida H, Ogata C, Arai T, Sato S: Episome mediated transfer on drug resistance in Enterobacteriaceae. VII. Two types of naturally occuring R factors. J Bact 88:922-8, 1964.

141. Tomoeda M, Inuzuka M, Kubo N, Nakamura S. Effective elimination of drug resistance and sex factors in Escherichia coli by sodium dodecyl sulfate. J Bacteriol. 95(3):1078-89,1968.

142. Keyhani J, Keyhani E, Attar F, Haddadi A. Sensitivity to detergents and plasmid curing in Enterococcus faecalis. J Ind Microbiol Biotechnol. 2005 Sep 23; [Epub ahead of print]

143. Kampmann M, Stock D: Reverse gyrase has heat-protective DNA chaperone activity independent of supercoiling. Nucleic Acids Research 32(12):3537-3545, 2004.

144. Nikaido H: Molecular basis of bacterial outer membrane permeability revisited. Microbiol Mol Biol Rev. 67(4):593-656. 2003.

145. De E, Basle A, Jaquinod M, Saint N, Mallea M, Molle G, Pages JM: A new mechanism of antibiotic resistance in Enterobacteriaceae induced by a structural modification of the major porin. Mol Microbiol 41(1):189-98, 2001.

146. Poole K: Outer membranes and efflux: the path to multidrug resistance in Gram-negative bacteria. Curr Pharm Biotechnol. 3(2):77-98, 2002.

147. Poole K: Efflux-mediated multiresistance in Gram-negative bacteria. Clin Microbiol Infect. 10(1):12-26, 2004.

148. Actis LA, Tolmasky ME, Jorge H. Crosa JH: Bacterial plasmids: replication of extrachromosomal genetic elements encoding resistance to antimicrobial compounds. Frontiers in Bioscience 3, d43-62, January 1, 1998.

149. Denny WA: Chemotherapeutic Effects of Acridine Derivatives. Medicinal Chemistry Reviews Online, Volume 1, Number 3 pp. 257-266(10), 2004.

150. Amaral L, Viveiros M, Molnar J:Antimicrobial activity of phenothiazines. In Vivo. NovDec;18(6):725-31. 2004.

151. Yamaguchi A, Ono N, Akasaka T, Noumi T, Sawai T: Metal-tetracycline $/ \mathrm{H}^{+}$antiporter of Escherichia coli encoded by a transposon, Tn10. J. Biol. Chem. 265:15525-15530, 1990.

152. Rubin RA, Levy SB: Interdomain hybrid Tet proteins confer tetracycline resistance only when they are derived from closely related members of the tet gene family. J. Bacteriol. 173:45034509, 1991.

153. McNicholas P, Chopra I, Rothstein DM: Genetic analysis of the $\operatorname{Tet} \mathrm{A}(\mathrm{C})$ gene on plasmid pBR322. J. Bacteriol. 174:7926-7933, 1992.

154. McNicholas P, M. McGlynnG, Guay G, Rothstein DM: Genetic analysis suggests functional interactions between the $\mathrm{N}$ - and $\mathrm{C}$-terminal domains of the TetA(C) efflux pump encoded by pBR322. J. Bacteriol. 177:5355-5357, 1995.

155. Begue J-P, Bonnet-Delpon D.: Preparation of trifluoromethyl ketones and related fluorinated ketones. Tetrahedron 47:3207-58, 1991.

156. Ogilvie W, Bailey M, Poupart M-A et al.: Peptidomimetic inhibitors of the human cytomegalovirus protease. J Med Chem 40:4113-35, 1997. 
157. Kawase M., Motohashi N., Sakagami H, Kanamoto T. et al.: Antimicrobial activity of trifluoromethyl ketones and their synergism with promethazine. International Journal of Antimicrobial Agents 18:161-165, 2001.

158. Kaatz GW, Moudgal VV, Seo SM, Kristiansen JE: Phenothiazines and thioxanthenes inhibit multidrug efflux pump activity in Staphylococcus aureus. Antimicrobial Agents and Chemotherapy, Vol. 47, No. 2, p. 719-726, 2003.

159. Van Bambeke F, Balzi E, Tulkens PM: Antibiotic efflux pumps. Biochem. Pharmacol. 60:457$470,2000$.

160. Kristiansen JE, Amaral L:. The potential management of resistant infections with nonantibiotics. J Antimicrob Chemother 40:319-327, 1997.

161. Rosen BP, McClees JS: Active Transport of Calcium in Inverted Membrane Vesicles of Escherichia coli. PNAS Vol. 71,No. 12,5042-5046, 1974.

162. Holland IB, Jones HE, Campbell AK, Jacq A: An assessment of the role of intracellular free $\mathrm{Ca}^{2+}$ in E. coli. Biochimie. 81(8-9):901-7, 1999.

163. Asai Y, Yakushi T, Kawagishi I, Homma M: Ion-coupling determinants of $\mathrm{Na}+$-driven and $\mathrm{H}+-$ driven flagellar motors. J Mol Biol. 21;327(2):453-63, 2003.

164. Kim MJ, Bird JC, Van Parys AJ, Breuer KS, Powers TR: A macroscopic scale model of bacterial flagellar bundling. PNAS 100(26)15481-15485, 2003.

165. Gabel CV, Berg HC: The speed of the flagellar rotary motor of Escherichia coli varies linearly with protonmotive force. PNAS 100(15)8748-8751, 2003.

166. Niehus E, Gressmann H, Ye F, Schlapbach R, Dehio M, Dehio C, Stack A, Meyer TF, Suerbaum S, Josenhans C: Genome-wide analysis of transcriptional hierarchy and feedback regulation in the flagellar system of Helicobacter pylori. Molecular Microbiology 52(4):947961, 2004.

167. Jenks PJ, Foynes S, Ward SJ, Costantinidou C, Penn CW, Wren BW: A flagellar-specific ATPase (FliI) is necessary for flagellar export in Helicobacter pylori. FEMS Microbiology Letters 152:205-211, 1997.

168. Mazurkiewicz P, Driessen AJ, Konings WN. What do proton motive force driven multidrug resistance transporters have in common? Curr Issues Mol Biol. 7(1):7-21, 2005.

169. Molnár J, Szabó D, Mándi Y, Mucsi I, Fischer J, Varga A, König S, Motohashi N: Multidrug resistance reversal in mouse lymphoma cells by heterocyclic compounds. Anticancer Res 18:3033-3038, 1998.

170. Hevér A, Santelli-Rouvier C, Brouant P, El Khyari S, Molnár J, Barra Y, Barbe J: Effect of new thioacridine derivatives on P-gp function and on mdr1 gene expression. Anticancer Res 18:3053-3058, 1998.

171. Zamora JM, Pearce HL, Beck WT: Physical-chemical properties shared by compounds that modulate multidrug resistance in human leukemic cells. Mol Pharmcol 33:454-462, 1988.

172. Lee JS, Paull K, Alvarez M, Hose C, Monks A, Grever M, Fojo AT, Bates SE: Rhodamine efflux patterns predict P-glycoprotein substrates in the National Cancer Institute Drug Screen. Mol Pharmacol 46(4):627-38,1994.

173. Klopman G, Shi LM, Ramu A: Quantitative structure-activity relationship of multidrug resistance reversal agents. Mol Pharmacol 52(2):323-34, 1997.

174. Mallavadhani UV, Panda AK, Rao YR: Pharmacology and chemotaxonomy of Diospyros. Phytochemistry 49(4):901-51, 1998.

175. Chen G, Lu H, Wang C, Yamashita K, Manabe M, Meng Z, Xu S, Kodama H: Effect of five flavonoid compounds isolated from leaves of Diospyros kaki on stimulus-induced superoxide generation and tyrosyl phosphorylation of proteins in human neutrophils. Clin Chim Acta. 326(1-2):169-75, 2002. 


\section{ACKNOWLEDGEMENTS}

First of all I would like to express my deep and sincere gratitude to my supervisor, Professor József Molnár. His wide knowledge and his way of thinking have been of great value to me. His understanding, encouraging and personal guidance served as an excellent basis for the preparation of the present Ph.D. thesis.

I would like to express my sincere gratitude to Prof. Yvette Mándi, chair of the department, for providing possibility to work at the department.

I would like to give my special thanks to Annamária Molnár, dr. Gergely Klausz, Csilla Miskolci, Krisztina Wolfárt, Mrs Vigyikán Anikó Váradi and my colleagues from the Department of Medical Microbiology and Immunobiology, who all supported me in my research work. I want to thank them for all their help, support and interest shown.

I am deeply grateful to Dr. András Miczák (Department of Medical Microbiology and Immunobiology, Faculty of Medicine, University of Szeged), Professor Derek Sharples (School of Pharmacy and Pharmaceutical Sciences, University of Manchester, United Kingdom), Dr. András Varga (Humboldt University, Berlin, Germany), Dr. Andreas Hilgeroth (Faculty of Pharmacy, Martin Luther University Halle-Wittenberg), Dr. János Kiss (Department of Organic Chemistry,University of Szeged, Hungary) for their help, support and constructive comments.

I would like to thank Mrs Erzsébet Magyaródi for her help and Dr. Imre Ocsovszki for performing the flow-cytometric measurements.

This study has been supported by various organizations including ,Foundation for Cancer Research Szeged”, „RICHTER GEDEON CENTENÁRIUMI ALAPÍTVÁNY”, COST B16 STSM grant. I thank them all for their confidence in me and for their support to complete my research.

I feel a deep sense of gratitude for my family, my parents, my sister and my brother for always being ready to help when I needed them most, and for supporting me through all these years. This thesis is dedicated to the memory of my grandmother who died in cancer in 2004 .

I heartfully thank my personal friends for their encouraging and help.

I would like to express thankfullness to all those who made it possible for me to complete this thesis. 


\section{APPENDIX \\ Structures of compounds investigated}

\section{Phenothiazines}

Promethazine<smiles>CC(CN1c2ccccc2Sc2ccccc21)N(C)C</smiles>

Trifluoperazine<smiles>CCCN1CCN(C)CC1</smiles>

\section{Acridines}

9-aminoacridine<smiles>Nc1c2ccccc2nc2ccccc12</smiles>

Acridine orange<smiles>CN(C)c1ccc2cc3ccc(N(C)C)cc3nc2c1</smiles>

3. Trifluoroketones: 1-(2-benzoxazolyl)-3,3,3-trifluoro-2-propanone [TF18]<smiles>CC(C)(F)OCc1nc2ccccc2o1</smiles> 
4. Antiarrhytmics: Verapamil<smiles>COc1ccc(C(C)C)cc1CCCN(C)CCc1ccc(OC)c(OC)c1</smiles>

5. Benzonaphthyridine-5-one and 5-iminobenzonaphthyridine derivatives<smiles></smiles>

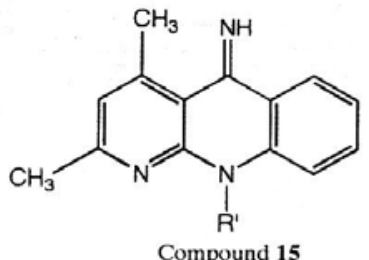

\begin{tabular}{|c|c|c|c|}
\hline Compounds & $\mathbf{R}$ & $\mathbf{R}^{\prime}$ & $\begin{array}{l}\text { Type of } \\
\text { nucleus }\end{array}$ \\
\hline 1 & - & 10-(2'-dimethylaminoethyl) & -5 -one \\
\hline 2 & - & 10-(3'-dimethylaminopropyl) & -5 -one \\
\hline 3 & - & 10-(2'-diethylaminoethyl) & -5-one \\
\hline 4 & - & 10-(2'-diisopropylaminoethyl) & -5-one \\
\hline 5 & - & 10-(2'-pyrrolidonoethyl) & -5 -one \\
\hline 6 & - & 10-(2'-(N-methyl)-pyrrolidinoethyl) & -5 -one \\
\hline 7 & & 10-(2'-piperidinoethyl) & -5-one \\
\hline 8 & - & 10-(3'-piperidinopropyl) & -5-one \\
\hline 9 & - & 10-(3'-(N-methyl)-piperazinopropyl) & -5-one \\
\hline 10 & - & 10-(2'-morpholinoethyl) & -5 -one \\
\hline 11 & & 10-(2'-diethylacedamido) & -5-one \\
\hline 12 & 9-methoxy & 10-(2'-diethylaminoethyl) & -5-one \\
\hline 13 & 9-methoxy & 10-(2'-diisopropylaminoethyl) & -5 -one \\
\hline 14 & 7,8-dimethoxy & 10-(2'-diethylaminoethyl) & -5 -one \\
\hline 15 & - & 10-(2'-diethylaminoethyl) & 5-imino- \\
\hline 16 & pyrazolo[4,5-a] & 3,6-bis(2'diethylaminoethyl) & -5 -one \\
\hline 17 & pyrazolo $[4,5-\mathrm{a}]$ & 1,6-bis(2-diethylaminoethyl) & -5-one \\
\hline 18 & imidazolo-2-one[4,5-b] & 1,3,10-tris(2'-diethylaminoethyl) & -5 -one \\
\hline 19 & cyclopentyl-1,3-dioxy[4,5-b] & 10-(2'-diethylaminoethyl) & -5 -one \\
\hline 20 & 1,4-dioxano $[5,6-\mathrm{b}]$ & 11-(2'-diethylaminoethyl) & -5-one \\
\hline 21 & benzothiazolo $[4,5-\mathrm{a}]$ & 6-(2'-diethylaminoethyl) & -5-one \\
\hline
\end{tabular}

Benzo[b]-1,8-naphthyridine-5-one derivatives [1-14], 5-imino-benzo[b]-1,8-naphthyridine derivative [15], tetracyclic derivatives of benzo[b]-1,8-naphthyridine-5-one [16-21] 


\section{Pregnane derivatives}

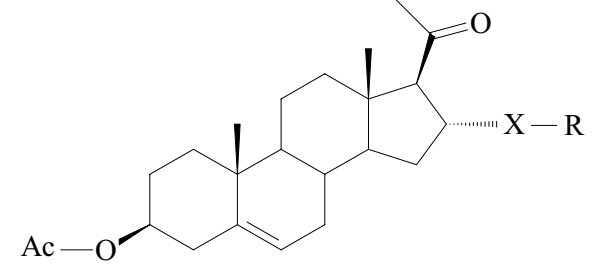

\begin{tabular}{|l|l|l|}
\hline Compound & X & R \\
\hline P-S1Be & $-\mathrm{S}-$ & $-\mathrm{CH}_{2} \mathrm{C}_{6} \mathrm{H}_{5}$ \\
\hline P-S1cHe & $-\mathrm{S}-$ & $-\mathrm{C}_{6} \mathrm{H}_{11}$ \\
\hline P-S2Be & $-\mathrm{SO}-$ & $-\mathrm{CH}_{2} \mathrm{C}_{6} \mathrm{H}_{5}$ \\
\hline P-S2cHe & $-\mathrm{SO}-$ & $-\mathrm{C}_{6} \mathrm{H}_{11}$ \\
\hline P-S3Be & $-\mathrm{SO}_{2-}$ & $-\mathrm{CH}_{2} \mathrm{C}_{6} \mathrm{H}_{5}$ \\
\hline P-S3cHe & $-\mathrm{SO}_{2-}$ & $-\mathrm{C}_{6} \mathrm{H}_{11}$ \\
\hline
\end{tabular}

\section{Monosubstituted pyrido[3,2-g]quinolines (4a-d)}<smiles>[Y7]c1cc(OCCN([R])[R])c2cc3cccnc3c(C)c2n1</smiles>

4a $\mathrm{R}_{1}=\mathrm{R}_{2}=$ ethyl

4b $\mathrm{R}_{1}=\mathrm{R}_{2}=$ isopropyl

4c $\mathrm{R}_{1}=\mathrm{R}_{2}=$ pyrrolidinyl

4d $\mathrm{R}_{1}=\mathrm{R}_{2}=$ piperidinyl

2,10-Dimethylpyrido-4-(2'-diethylaminoethoxy)-[3,2-g]quinoline (4a), 2,10-Dimethylpyrido4-(2'-diisopropylaminoethoxy)-[3,2-g]quinoline (4b), 2,10-Dimethylpyrido-4-(2'-(Npyrrolidino)ethoxy)-[3,2-g]quinoline (4c), 2,10-Dimethylpyrido-4-(2'-(N-piperidino)ethoxy)[3,2-g]quinoline (4d)

\section{Aza-fluorenes (Az1-3)}

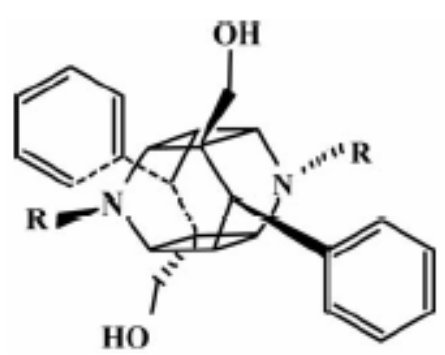

$\begin{array}{ll} & \text { R } \\ \text { Az1 } & \text { Benzyl } \\ \text { Az2 } & \mathrm{CO}_{2} \text { Phenyl } \\ \mathbf{A z 3} & \mathrm{CO}_{2} \mathrm{CH}_{3}\end{array}$

3,9-dibenzyl-1,5,7,11-tetrahydroxymethyl-6,12-diphenyl-3,9-diazahexacyclo[6.4.0.0 $\left.0^{2.7} \cdot 0 .^{4.11} \cdot 0 .^{5.10}\right]$-dodecane (Az1) 1,7-dihydroxymethyl-6,12-diphenyl-3,9-diphenoxycarbonyl-3,9diazahexacyclo[6.4.0.0.0.7.0. $\left.0 .^{4.11} \cdot 0 .^{5.10}\right]$-dodecane (Az2)

1,7- dihydroxymethyl-3,9-dimethoxycarbonyl-6,12-diphenyl-3,9-diazahexacyclo $\left[6.4 .0 .0^{2.7} \cdot 0 .^{4.11} \cdot 0{ }^{5.10}\right]$-diazahexacyclododecane (Az3) 


\section{Coumarin derivatives $[\mathrm{C} 1-44]$}<smiles></smiles>

\begin{tabular}{|c|c|c|}
\hline Compd & $\mathrm{R}^{1}$ & $\mathrm{R}^{2}$ \\
\hline 1 & $\mathrm{H}$ & $\mathrm{H}$ \\
\hline 2 & $\mathrm{H}$ & $\mathrm{H}$ \\
\hline 3 & $\mathrm{H}$ & $\mathrm{H}$ \\
\hline 4 & $\mathrm{H}$ & $\mathrm{H}$ \\
\hline 5 & $\mathrm{H}$ & $\mathrm{H}$ \\
\hline 6 & $\mathrm{H}$ & $\mathrm{CH}_{3}$ \\
\hline 7 & $\mathrm{H}$ & $\mathrm{CH}_{3}$ \\
\hline 8 & $\mathrm{H}$ & $\mathrm{CH}_{3}$ \\
\hline 9 & $\mathrm{H}$ & $\mathrm{CH}_{3}$ \\
\hline 10 & $\mathrm{H}$ & $\mathrm{CH}_{3}$ \\
\hline 11 & $\mathrm{H}$ & $\mathrm{CH}_{3}$ \\
\hline 12 & $\mathrm{H}$ & $\mathrm{CH}_{3}$ \\
\hline 13 & $\mathrm{H}$ & $\mathrm{CH}_{3}$ \\
\hline 14 & $\mathrm{CH}_{3}$ & $\mathrm{H}$ \\
\hline 15 & $\mathrm{CH}_{3}$ & $\mathrm{CH}_{3}$ \\
\hline 16 & $\mathrm{CH}_{3}$ & $\mathrm{CH}_{3}$ \\
\hline 17 & $\mathrm{CH}_{3}$ & $\mathrm{CH}_{3}$ \\
\hline 18 & $\mathrm{CH}_{3}$ & $\mathrm{CH}_{3}$ \\
\hline 19 & $\mathrm{CH}_{3}$ & $\mathrm{CH}_{3}$ \\
\hline 20 & $-\left(\mathrm{CH}_{2}\right)_{3-}$ & \\
\hline 21 & $-\left(\mathrm{CH}_{2}\right)_{3-}^{-}$ & \\
\hline 22 & $-\left(\mathrm{CH}_{2}\right)_{3}$ & \\
\hline 23 & $-\left(\mathrm{CH}_{2}\right)_{3}$ & \\
\hline 24 & $-\left(\mathrm{CH}_{2}\right)_{4^{-}}$ & \\
\hline 25 & -Benzo- & \\
\hline 26 & $\mathrm{H}$ & $\mathrm{CH}_{2} \mathrm{CO}_{2} \mathrm{H}$ \\
\hline 27 & $\mathrm{NO}_{2}$ & $\mathrm{OH}^{2}$ \\
\hline 28 & $\mathrm{CO}_{2} \mathrm{C}_{2} \mathrm{H}_{5}$ & $\mathrm{H}$ \\
\hline 29 & $\mathrm{H}$ & $\mathrm{Ph}$ \\
\hline 30 & $\mathrm{Ph}$ & $\mathrm{CH}_{3}$ \\
\hline 31 & $\mathrm{H}$ & $\mathrm{CF}_{3}$ \\
\hline 32 & $\mathrm{H}$ & $\mathrm{CF}_{3}$ \\
\hline 33 & $\mathrm{CH}_{3}$ & $\mathrm{CH}_{3}$ \\
\hline 34 & $\left(\mathrm{CH}_{2}\right)_{2} \mathrm{OH}$ & $\mathrm{CH}_{3}$ \\
\hline 35 & $\left(\mathrm{CH}_{2}\right)_{2} \mathrm{OH}$ & $\mathrm{CH}_{3}$ \\
\hline 36 & $\left(\mathrm{CH}_{2}\right)_{2} \mathrm{OH}$ & $\mathrm{CH}_{3}$ \\
\hline 37 & $\left(\mathrm{CH}_{2}\right)_{2} \mathrm{OH}$ & $\mathrm{CH}_{3}$ \\
\hline 38 & $\mathrm{H}$ & $\mathrm{CH}_{2} \mathrm{CO}_{2} \mathrm{CH}_{3}$ \\
\hline 39 & $\mathrm{CH}_{3}$ & $\mathrm{CH}_{3}$ \\
\hline 40 & $\mathrm{H}$ & $\mathrm{C}_{3} \mathrm{H}_{7}$ \\
\hline 41 & $\mathrm{H}$ & $\mathrm{CH}\left(\mathrm{CH}_{3}\right)_{2}$ \\
\hline 42 & $\mathrm{C}_{4} \mathrm{H}_{9}$ & $\mathrm{CH}_{3}$ \\
\hline 43 & $\mathrm{CH}\left(\mathrm{CH}_{3}\right)_{2}$ & $\mathrm{CH}_{3}$ \\
\hline 44 & $\mathrm{C}_{2} \mathrm{H}_{5}$ & $\mathrm{CH}_{3}$ \\
\hline & & \\
\hline
\end{tabular}

\begin{tabular}{|c|c|c|c|c|}
\hline$R^{3}$ & $\mathrm{R}^{4}$ & $\mathrm{R}^{5}$ & $R^{6}$ & Calcd $\log$ \\
\hline $\mathrm{H}$ & $\mathrm{H}$ & $\mathrm{H}$ & $\mathrm{H}$ & 1.41 \\
\hline $\mathrm{H}$ & $\mathrm{H}$ & $\mathrm{OH}$ & $\mathrm{H}$ & 1.61 \\
\hline $\mathrm{H}$ & $\mathrm{OH}$ & $\mathrm{OH}$ & $\mathrm{H}$ & 1.21 \\
\hline $\mathrm{H}$. & $\mathrm{OCH}_{3}$ & $\mathrm{OH}$ & $\mathrm{H}$ & 1.33 \\
\hline $\mathrm{OCH}_{3}$ & $\mathrm{OCH}_{3}$ & $\mathrm{OH}$ & $\mathrm{H}$ & 0.72 \\
\hline $\mathrm{H}$ & $\mathrm{H}$ & $\mathrm{OH}$ & $\mathrm{H}$ & 2.11 \\
\hline $\mathrm{H}$ & $\mathrm{OH}$ & $\mathrm{H}$ & $\mathrm{H}$ & 2.11 \\
\hline $\mathrm{H}$ & $\mathrm{OH}$ & $\mathrm{OH}$ & $\mathrm{H}$ & 1.71 \\
\hline $\mathrm{OH}$ & $\mathrm{H}$ & $\mathrm{OH}$ & $\mathrm{H}$ & 1.64 \\
\hline $\mathrm{H}$ & $\mathrm{OH}$ & $\mathrm{OCH}_{3}$ & $\mathrm{H}$ & 1.83 \\
\hline $\mathrm{H}$ & $\mathrm{OCH}_{3}$ & $\mathrm{OH}$ & $\mathrm{H}$ & 1.83 \\
\hline H & $\mathrm{H}$ & $\mathrm{OCH}_{3}$ & $\mathrm{H}$ & 2.24 \\
\hline H & $\mathrm{OCH}_{3}$ & $\mathrm{H}$ & $\mathrm{H}$ & 2.24 \\
\hline H & $\mathrm{H}$ & $\mathrm{OH}$ & $\mathrm{H}$ & 2.11 \\
\hline H & $\mathrm{H}$ & $\mathrm{OH}$ & $\mathrm{H}$ & 2.56 \\
\hline $\mathrm{H}$ & $\mathrm{OH}$ & $\mathrm{OH}$ & $\mathrm{H}$ & 2.16 \\
\hline $\mathrm{H}$ & $\mathrm{OH}$ & $\mathrm{OCH}_{3}$ & $\mathrm{H}$ & 2.28 \\
\hline $\mathrm{H}$ & $\mathrm{OCH}_{3}$ & $\mathrm{OH}$ & $\mathrm{H}$ & 2.28 \\
\hline $\mathrm{H}$ & $\mathrm{H}$ & $\mathrm{OCH}_{3}$ & $\mathrm{OH}$ & 2.28 \\
\hline $\mathrm{H}$ & $\mathrm{OH}$ & $\mathrm{OH}$ & $\mathrm{H}$ & 2.22 \\
\hline $\mathrm{OH}$ & $\mathrm{H}$ & $\mathrm{OH}$ & $\mathrm{H}$ & 2.15 \\
\hline $\mathrm{H}$ & $\mathrm{OH}$ & $\mathrm{OCH}_{3}$ & $\mathrm{H}$ & 2.35 \\
\hline $\mathrm{H}$ & $\mathrm{OCH}_{3}$ & $\mathrm{OH}$ & $\mathrm{H}$ & 2.35 \\
\hline $\mathrm{H}$ & $\mathrm{OH}$ & $\mathrm{OCH}_{3}$ & $\mathrm{H}$ & 2.91 \\
\hline H & $\mathrm{NO}_{2}$ & $\mathrm{H}$ & $\mathrm{H}$ & - \\
\hline H & $\mathrm{H}$ & $\mathrm{OCH}_{3}$ & $\mathrm{H}$ & 1.01 \\
\hline $\mathrm{H}$ & $\mathrm{H}$ & $\mathrm{H}$ & $\mathrm{H}$ & - \\
\hline $\mathrm{H}$ & $\mathrm{H}$ & $\mathrm{H}$ & $\mathrm{H}$ & 1.91 \\
\hline $\mathrm{H}$ & $\mathrm{OH}$ & $\mathrm{OCH}_{3}$ & $\mathrm{H}$ & 3.22 \\
\hline $\mathrm{H}$ & $\mathrm{OH}$ & $\mathrm{OCH}_{3}$ & $\mathrm{H}$ & 3.93 \\
\hline $\mathrm{H}$ & $\mathrm{OH}$ & $\mathrm{OCH}_{3}$ & $\mathrm{H}$ & 2.25 \\
\hline $\mathrm{H}$ & $\mathrm{H}$ & $\mathrm{N}\left(\mathrm{CH}_{3}\right)_{2}$ & $\mathrm{H}$ & 3.01 \\
\hline $\mathrm{H}$ & OR & $\mathrm{OH}$ & $\mathrm{H}$ & 4.79 \\
\hline $\mathrm{H}$ & $\mathrm{OH}$ & $\mathrm{OCH}_{3}$ & $\mathrm{H}$ & 0.82 \\
\hline $\mathrm{H}$ & $\mathrm{H}$ & $\mathrm{OH}$ & $\mathrm{OH}$ & 0.70 \\
\hline $\mathrm{H}$ & $\mathrm{OCH}_{3}$ & $\mathrm{OH}$ & $\mathrm{H}$ & 0.82 \\
\hline $\mathrm{OH}$ & & $\mathrm{OH}$ & $\mathrm{H}$ & 0.63 \\
\hline $\mathrm{H}$ & $\mathrm{OH}$ & $\mathrm{OCH}_{3}$ & $\mathrm{H}$ & 1.01 \\
\hline $\mathrm{H}$ & $\mathrm{OH}$ & $\mathrm{OC}_{2} \mathrm{H}_{5}$ & $\mathrm{H}$ & 2.81 \\
\hline $\mathrm{H}$ & $\mathrm{OH}$ & $\mathrm{OCH}_{3}$ & $\mathrm{H}$ & 2.89 \\
\hline $\mathrm{H}$ & $\mathrm{OH}$ & $\mathrm{OCH}_{3}$ & $\mathrm{H}$ & 2.76 \\
\hline $\mathrm{H}$ & $\mathrm{OH}$ & $\mathrm{OCH}_{3}$ & $\mathrm{H}$ & 3.87 \\
\hline $\mathrm{H}$ & $\mathrm{OH}$ & $\mathrm{OCH}_{3}$ & $\mathrm{H}$ & 3.21 \\
\hline $\mathrm{H}$ & $\mathrm{OH}$ & $\mathrm{OCH}_{3}$ & $\mathrm{H}$ & 2.81 \\
\hline
\end{tabular}

Coumarins [C1-23] were previously synthesised (109), 6,7,8,9,10-Tetrahydro-2-hydroxy-3-methoxy-6Hdibenzo[b,d]pyran-6-one [C24]: 6-nitro-3,4-benzocoumarin [C25], 7-methoxycoumarin-4-acetic acid [C26], 4hydroxy-3-nitrocoumarin [C27], ethyl coumarin-3-carboxylate [C28], Hydroxy-7-methoxy-4-phenyl-2H-1benzopyran-2-one [C29], 6-Hydroxy-7-methoxy-4-methyl-3-phenyl-2H-1-benzopyran-2-one [C30] 6-Hydroxy7-methoxy-4-trifluoromethyl-2H-1-benzopyran-2-one [C31],4-trifluoromethyl-7-dimethylaminocoumarin [C32] 7-Hydroxy-6-\{3-[4-(2-methoxyphenyl)-1-piperazinyl]propoxy $\}-3,4-d i m e t h y l-2 H$-1-benzopyran-2-one [C33] 6Hydroxy-3-(2-hydroxyethyl)-7-methoxy-4-methyl-2H-1-benzopyran-2-one [C34] 7,8-Dihydroxy-3-(2hydroxyethyl)-4-methyl-2H-1-benzopyran-2-one [C35] 7-Hydroxy-3-(2-hydroxyethyl)-6-methoxy-4-methyl2H-1-benzopyran-2-one [C36] 5,7-Dihydroxy-3-(2-hydroxyethyl)-4-methyl-2H-1-benzopyran-2-one [C37] 2-(6Hydroxy-7-methoxy-2-oxo-2H-1-benzopyran-4-yl)acetic acid methylester [C38] 7-Ethoxy-6-hydroxy-3,4dimethyl-2H-1-benzopyran-2-one [C39] 6-Hydroxy-7-methoxy-4-propyl-2H-1-benzopyran-2-one [C40] 6Hydroxy-7-methoxy-4-(1-methylethyl)-2H-1-benzopyran-2-one [C41] 3-Butyl-6-hydroxy-7-methoxy-4-methyl2H-1-benzopyran-2-one [C42] 6-Hydroxy-7-methoxy-4-methyl-3-(1-methylethyl)-2H-1-benzopyran-2-one [C43] 3-Ethyl-6-hydroxy-7-methoxy-4-methyl-2H-1-benzopyran-2-one [C44] 


\section{Cycloartanes}

Chemical structures of cycloartane triterpenes.

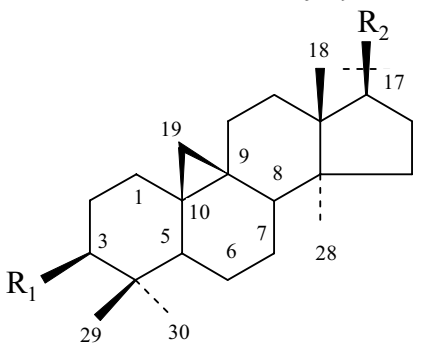

$\mathrm{R}_{1}$

$1 \mathrm{OH}$<smiles>CC(C)CCC(O)C(C)(C)O</smiles>
7 8 $\mathrm{OH}$
$\mathrm{R}_{1}$

$\mathrm{R}_{2}$

$2 \mathrm{OH}$<smiles>CC(C)CCCC(C)CO</smiles>

$3 \mathrm{OH}$

12 OAc<smiles>C=C(C)C(=O)CCC(C)C</smiles>

9

$\mathrm{OH}$ $\mathrm{OH}$<smiles>[3H][C](C)CCCC(C)C</smiles>

10

OAc<smiles>CC(C)C=CC=O</smiles>

$4 \mathrm{OH}$<smiles>CC(C)C/C=C/C(C)(C)O</smiles>

$5 \mathrm{OH}$<smiles>C=C(C)C(CCC(C)C)OO</smiles>
11

$\mathrm{OH}$ OAc<smiles>CC(C)CCC=O</smiles><smiles>C=C(C)C(CCC(C)C)OC(C)=O</smiles>

OAc

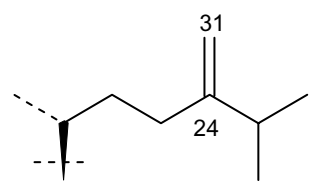

$6 \mathrm{OH}$<smiles>C=C(C)C(O)CCC(C)C</smiles>

14<smiles>CC(C)=CCCC(C)C</smiles>

The tested set differs by the substitution and length of their side-chain and/or substitution at C-3:9,19-

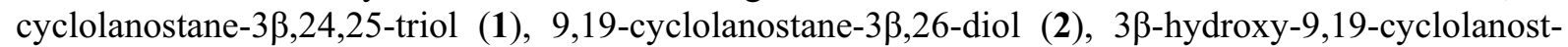

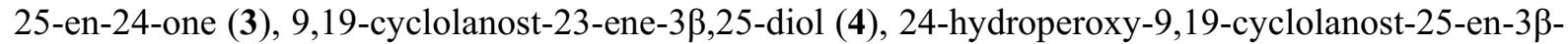

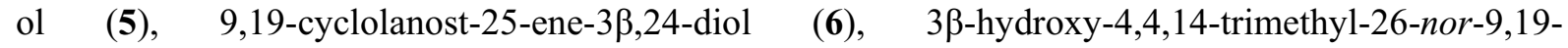

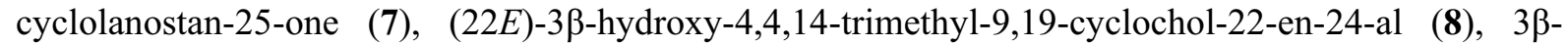
hydroxy-4,4,14-trimerhyl-9,19-cyclocholan-24-al (9), 9,19-cyclolanost-25-ene-3 $\beta, 24$-diacetate (10),

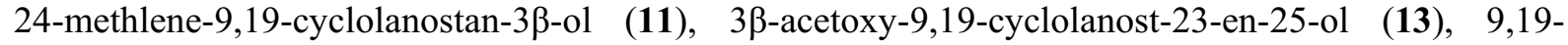

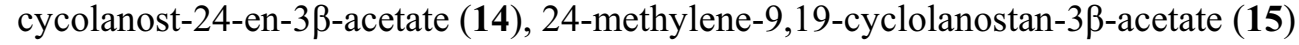

Compounds 10,12,13-15 were isolated from the acetone extract of Euphorbia segetalis L. Compounds 1-9 and 11 were isolated from the acetone extract of Euphorbia portlandica L. and identified by spectroscopic methods. All compounds were dissolved in DMSO. 


\section{PUBLICATIONS}

